Andrews University

Digital Commons @ Andrews University

1984

\title{
An Evaluation Of Current Procedures Of Local Conference Constituency Sessions With Recommendations For Possible Improvement
}

Jere D. Patzer

Andrews University

Follow this and additional works at: https://digitalcommons.andrews.edu/dmin

Part of the Practical Theology Commons

\section{Recommended Citation}

Patzer, Jere D., "An Evaluation Of Current Procedures Of Local Conference Constituency Sessions With Recommendations For Possible Improvement" (1984). Professional Dissertations DMin. 215.

https://dx.doi.org/10.32597/dmin/215

https://digitalcommons.andrews.edu/dmin/215

This Project Report is brought to you for free and open access by the Graduate Research at Digital Commons @ Andrews University. It has been accepted for inclusion in Professional Dissertations DMin by an authorized administrator of Digital Commons @ Andrews University. For more information, please contact repository@andrews.edu. 


\section{INFORMATION TO USERS}

This manuscript has been reproduced from the microfilm master. UMI films the text directly from the original or copy submitted. Thus, some thesis and dissertation copies are in typewriter face, while others may be from any type of computer printer.

The quality of this reproduction is dependent upon the quality of the copy submitted. Broken or indistinct print, colored or poor quality illustrations and photographs, print bleedthrough, substandard margins, and improper alignment can adversely affect reproduction.

In the unlikely event that the author did not send UMI a complete manuscript and there are missing pages, these will be noted. Also, if unauthorized copyright material had to be removed, a note will indicate the deletion.

Oversize materials (e.g., maps, drawings, charts) are reproduced by sectioning the original, beginning at the upper left-hand corner and continuing from left to right in equal sections with small overlaps.

ProQuest Information and Learning 300 North Zeeb Road, Ann Arbor, Ml 48106-1346 USA 800-521-0600

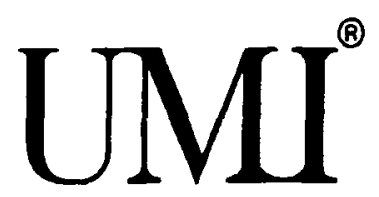


Reproduced with permission of the copyright owner. Further reproduction prohibited without permission. 


\title{
ABSTRACT \\ AN EVALUATION OF CURRENT PROCEDURES OF LOCAL CONFERENCE CONSTITUENCY SESSIONS WITH RECOMMENDATIONS FOR POSSIBLE IMPROVEPENT
}

\author{
by \\ Jere D. Patzer
}

Chaiman: Arnold Kurtz 


\title{
ABSTRACT OF GRADUATE STUDENT RESEARCH
}

Project Report

Andrews University

Seventh-day Adventist Theological Seminary

\section{Title: AN EVALUATION OF CURRENT PROCEDURES OF LOCAL CONFERENCE CONSTITUENCY SESSIONS HITH RECOMPENDATIONS FOR. POSSIBLE IMPROVEMENT}

Name of researcher: Jere D. Patzer

Name and degree of faculty adviser: Arnold A. Kurtz, Ph. D. Date completed: May 1984

\section{Problem}

There is a growing dissatisfaction being openly expressed toward the current procedures pertaining to constituency sessions. The perception of many constituents is that these meetings are held for the purpose of "rubber stamping" what has al ready been decided.

\begin{abstract}
Method
In cooperation with my major professor and the Andrews University Institute of Church Ministry, I decided that an evaluation instrument in the form of a survey would be sent to a sample of the delegates present at the 1980 Upper Columbia and Idaho conferences and the 1983 Upper Columbia conference
\end{abstract}


constituency sessions. Sone of the findings from the 1980 surveys were used to form the planning for the 1983 session.

\section{Resuits}

The satisfaction level of those surveyed who attended the 1983 Upper Columbia conference constituency session were considerably higher than that of those who were surveyed from the 1980 Upper Columbia and Idaho conference constituency sessions. Likewise, the credibility ratings of the conference leadership was considerably higher than that of those sampled who attented the 1983 Upper Columbia constituency session as opposed to the 1980 Upper Colunbia and Idaho conferences constituency sessions.

\section{Conclusions}

The laity surveyed lant to be active participants in the developing or approving of plans for the future of their conferences rather than be entertained by reports of past accomplishments. When they were given this opportunity, their satisfaction level with the vay the business of the church was conducted rose considerably. 
Reproduced with permission of the copyright owner. Further reproduction prohibited without permission. 


\author{
Andrews University \\ Seventh-day Adventist Theological Seminary
}
AN EVALUATION OF CURRENT PROCEDURES OF LOCAL CONFERENICE CONSTITUENCY SESSIONS
WITH RECOMMENDATIONS FOR
POSSIBLE IMPROVEMENT

\author{
A Project Report \\ Presented in Partial Fulfillment \\ of the Requirements for the Degree \\ Doctor of Ministry
}

by

Jere D. Patzer

May 1984 
UMI Number: 3096515

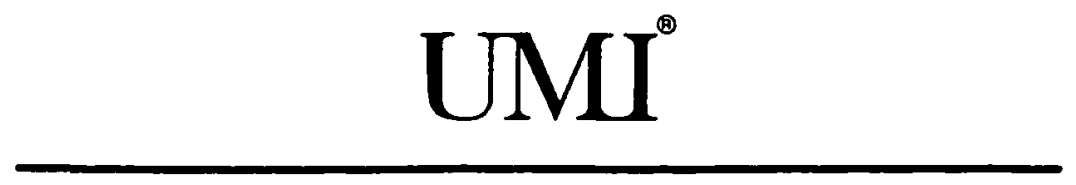

UMI Microform 3096515

Copyright 2003 by ProQuest Information and Learning Company. All rights reserved. This microform edition is protected against unauthorized copying under Title 17, United States Code.

ProQuest Information and Learning Company 300 North Zeeb Road

P.O. Box 1346

Ann Arbor, MI 48106-1346 


\section{AN EVALUATION OF CURRENT PROCEDURES OF LOCAL CONFERENCE CONSTITUENCY SESSIONS \\ WITH RECOMMENDATIONS FOR \\ POSSIBLE IMPROVEMENT}

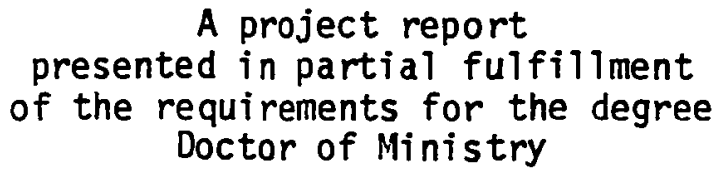

by

Jere D. Patzer

APPROYAL BY THE COMHITTEE:
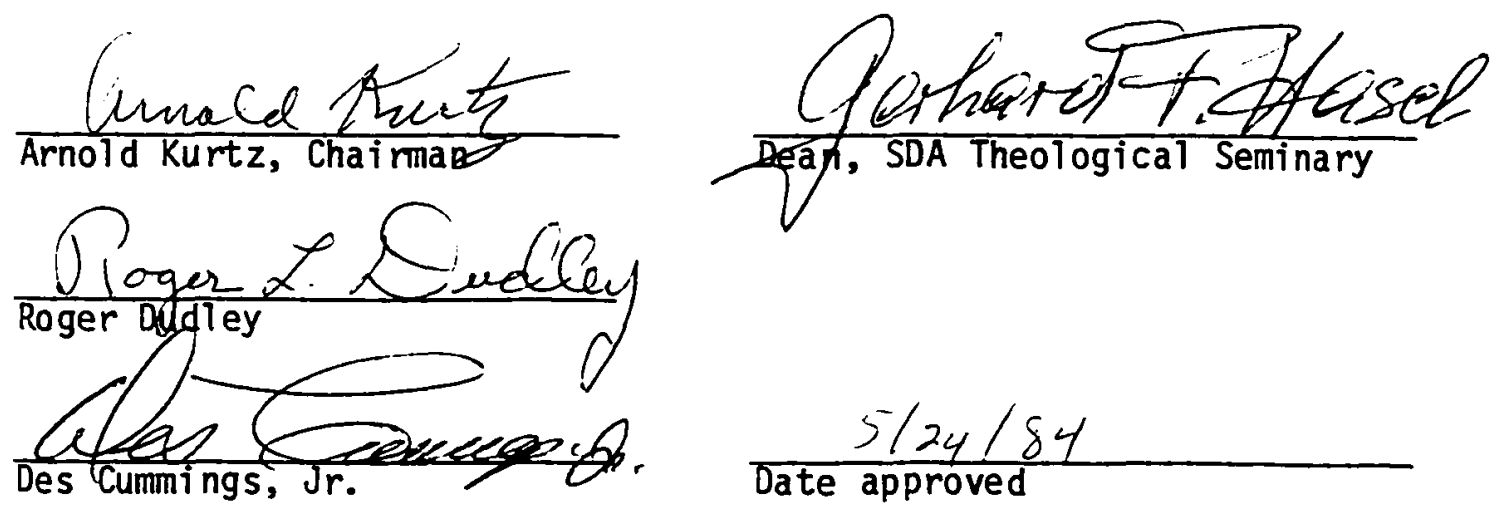

Reproduced with permission of the copyright owner. Further reproduction prohibited without permission. 
Reproduced with permission of the copyright owner. Further reproduction prohibited without permission. 
TABLE OF CONTENTS

ACKNOHLEDGEIENTS

Chapter

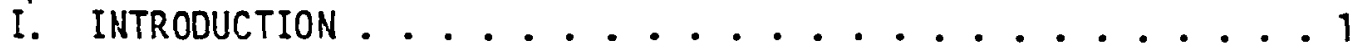

Purpose of the Project . . . . . . . . . . . 1

The Rationale for an Evaluation of Current Constituency Session Procedures ...............2

Format and Procedures Used in the Development and Implementation of the Testing Instrument.......5 Upper Columbia Conference. . . . . . . . . . . 5 Idaho Conference .............. 6 Sample. ................... 6

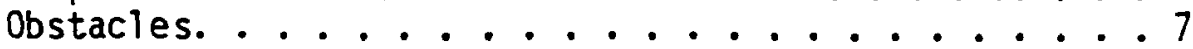

Procedure. . . . . . . . . . . . . . . 8

II. CONTEXT OF THE SDA CONFERENCE CONSTITUENCY SESSIONS . . . . ו

Historical Background. . . . . . . . . . . 11

Church Organization Emerges . . . . . . . . . . 12

Four Forms of Church Organization . . . . . . . 14

Michigan -- The First Organized Conference. . . . . . . 15

Contemporary Procedures . . . . . . . . . . 17

III. SURVEY OF TWO SAMPLE TRIENNIEL CONFERENCE CONSTITUENCY

SESSIONS. ................ 19

Satisfaction Level with Constituency Session. . . . . 20

Reasons for Satisfaction or Dissatisfaction ...... 23

Miscellaneous Conments Regarding Constituency Survey. . 25

Delegate Input in Sessions .......... 26

Credibility of Church Leadership. . . . . . . . . 27

De legate Involvement. ............. 29

Confidence in Church Leadership ............ . 31

Improving Constituency Sessions . . . . . . . . . 33

Comprehension Level of Delegates ........... 35

Purpose of Constituency Sessions. . . . . . . . . 37

Future Plans and Objectives ............ . 37

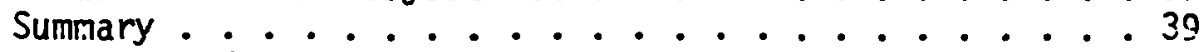

Suggestions for Hore Effective Meetings . . . . . . . 42

Delegate Input and Lay Involvement. . . . . . . . 41

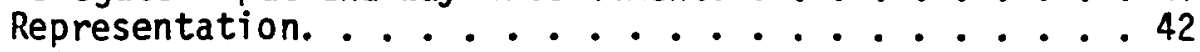

Prior Work and Information. ............444

Better/Different Organization ...........44 
Election Process. ............. 45

Reporting Honestly/Factualiy..........47

Spiritual Emphasis. . . . . . . . . . . 48

Commendation/Confidence/Sati sfaction. ...... 49

IV. STRATEGY FOR ADDRESSING FINDINGS OF THE 1980 UPPER COLUMBIA AND IDAHO CONFERENCE CONSTITUENCY SESSIONS AS CARRIED OUT IN THE UPPER COLUHBIA CONFERENCE WITH EVALUATION. . . . . 5

Preparation for the Session ........... . 51 Constituency Session Program ........... 54

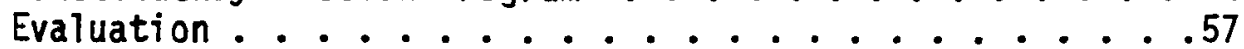

Comparison of Responses .......... . . 58

Understanding of Proceedings. . . . . . . . . . 664

Suggestions for Improvement ............667

Input by Lay Members. . . . . . . . . . . . 67

Representation. .............. 68

Election. ............. . 69

Prior Information and Hork. . . . . . . . . 69

Better/Different Organization . . . . . . . . . 71

Reporting Honestly/Factually ......... 72

Spiritual Emphasis More/Less . . . . . . . . 72

Commendations/Confidence/Satisfaction ...... 73

Sumary ................. 74

v. THEOLOGICAL AND THEORETICAL BRIEF WITH CONCLUSIONS. . . 75

Biblical Principles ............... . . 75

Some Reflections. ............... . 79

Implications Pertaining to Church Meetings. . . . . . 82

Conclusions .................. 84

VI. CONCLUSIONS AND RECOMMENDATIONS . . . . . . . 87

Specific Conclusions. . . . . . . . . . . 87

Recommendations............ 88

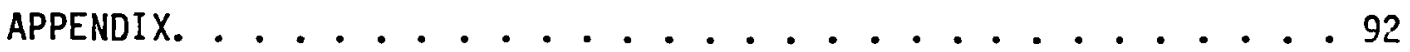

BIBLIOGRAPHY ........................... 113

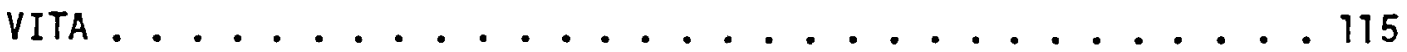




\section{LIST OF ILLUSTRATIONS}

1. Response Totals by Percentage to Question 1 by All Groups, 1980 Session and 1983 Session ......... 59

2. Response Totals by Percentage to Question 2 by All Groups, 1980 Session and 1983 Session ......... 60 60

3. Response Totals by Percentage to Question 3 by A11 Groups, 1980 Session and 1983 Session ........... 62

4. Response Totals by Percentage to Question 4 by All Groups, 1980 Session and 1983 Session .......... 63

5. Response Totals by Percentage to Question 5 by All Groups, 1980 Session and 1983 Session ......... 65

6. Pesponse Totals by Percentage to Question 7 by A11 Groups, 1980 Session and 1983 Session .......... 66

7. Response Totals by Percentage to Question 6 by All Groups, 1980 Session and 1983 Session ......... 107

8. Response Tota1s by Percentage to Question 8 by $A 11$ Groups, 1980 Session and 1983 Session ......... 108 


\section{LIST OF TABLES}

1. Conference Constituency Session Evaluation Sample Identification and Survey Return. . . . . . . . . 9

2. Demographic Characteristics of Respondents to Conference Constituency Session Evaluation by Number and Percentage . 10

3. Response Totals by Number and Percentage to Conference Constituency Session Evaluation by A11 Groups, Age, Representation, and Conference Specific -- Question 1. . 21

4. Response Totals by Number and Percentage to Conference Constituency Session Evaluation by All Groups, Age, Representation and Conference Specific -- Question 2 . . 24

5. Response Totals by Number and Percentage to Conference Constituency Session Evaluation by All Groups, Age, Representation and Conference Specific -- Question 3 . . 28

6. Response Totals by Number and Percentage to Conference Constituency Session Evaluation by All Groups, Age, Representation and Conference Specific -- Question 4 . . 30

7. Response Totals by Number and Percentage to Conference Constituency Session Evaluation by A11 Groups, Age, Representation and Conference Specific -- Question 5 . . 3?

8. Response Totals by Number and Percentage to Conference Constituency Session Evaluation by All Groups, Age, Representation and Conference Specific -- Question 6 . . 34

9. Response Totals by Number and Percentage to Conference Constituency Session Evaluation by All Groups, Age, Representation and Conference Specific -- Question 7 . . 36

10. Response Totals by Number and Percentage to Conference Consti tuency Session Evaluation by A11 Groups, Age, Representation and Conference Specific -- Question 8 . . 38

11. Response Totals by Weighted Numbers to Conference Constituency Session Evaluation Comparison of Upper Columbia Conference 1980 and 1983 Sessions -- Question 3 ... 109

12. Response Totals by Number and Percentage to Conference Constituency Session Evaluation, All Questions, by Representation .............. 110 


\section{ACKNOWLEDGMENTS}

It was Dr. Arnold Kurtz, director of the Andrews University doctor of ministry program, who had the faith in me to initially suggest that I begin the doctoral program. As my major professor, his guiding and encouraging hand saw me through to a successful completion of this project and the doctoral program in its entirety.

This project became a reality under the guidance of Dr. Roger Dudley of the Andrews University Institute of Church Ilinistry. His meticulous attention to detail was balanced by his ability to conceptualize the finished product.

The third nember of the reading project cormittee was Des Cummings, Jr. whose professionalism and friendship I have long appreciated.

The use of the data through tables and graphs was greatly enhanced by Janice Winslow. Her understanding of and experience with statistics was indispensible.

There is no way that I can adequately express my appreciation for my secretary, llarilee Thomas. The hours she has spent typing and retyping these pages have been a testimony to her competency and dedication. All the while she was cheerfully rolding down the demanding duties of secretary to an administrator.

The sacrifice that a wife and children make in terms of time and priorities are appreciated only by others who have experienced a similar study program. So Sue, Darin, and Troy, you, too, are a part of my success.

And, finally, the supreme commendation goes to the nuthor, Creator, and source of all true wisdom. It is to the finishing of his work that I dedicate myself and this project. 
CHAPTER I

INTRODUCT ION

Within the framework of the Seventh-day Adventist Church a conference is defined as "a unit of SDA church organization composed of the local churches within a given area, such as a state." 1

Every three years representatives from the churches composing these conferences convene in what is called a conference constituency session to:

1. Receive progress reports of the previous triennium

2. Elect conference officers and departmental directors

3. Lay plans for furthering the work of the church

Each church in the conference appoints delegates on the basis of church membership per current conference constitution. These delegates are to represent the best interest of the church at 1arge. Additionally, the information given in the reports is then to be shared by the delegates with the members of their respective churciles.

\section{Purpose of the Project}

An attempt is made through this project to evaluate the current structure of a local conference constituency session. This

1 "Local Conference," SDA Encyclopedia, 1976 ed., 10:346. 
includes taking a survey of church Teaders and constituents involved in the process.

Presently, hundreds of people come to constituency sessions. They spend money on travel and sit for thousands of hours. Until the writing of this project, little or no evaluation of this investment of time and money had been made.

Presunably, an involved constituency is a supportive constituency. If this is true, greater involvement by the laity could lead to a more successful accomplishment of the mission of the church.

In addition, the project considered the thenlogical rationale and implications of the political processes functioning within the church.

Finally, it was anticipated that some realistic, concrete recommendations would be forthcoming.

It was not the intent or purpose of this project to attack the existing procedures for conference sessions. It was realized, however, that as any institution develops, it must look constructively at itself if it is to make the necessary changes time and complexity demand to keep it from becoming dysfunctional.

It is for this reason that a project that evaluates one of the most fundarientai processes of the Adventist Church is defensible.

The Rationale for an Evaluation of Current Constituency Session Procedures

There is a growing dissatisfaction being openly expressed toward the current procedures pertaining to constituency sessions. 
The perception of many constituents is that these meetings are held for the purpose of "rubber stamping" what has already been decided.

It is overly simplistic to attribute the present situation merely to the fact that certain segments of the laity are now considerably more politically motivated. In actuality, many Seventh-day Adventist' people are looking for the opportunity to give meaningful input into the goals and plans of their church. This, in fact, should be looked upon as an asset rather than a liability. When this is realized, what usually is considered the problem becomes merely a symptom. The actual problem, according to this study, is the current structure and format which not only fails to foster creative input, but rather stifles it.

In the eyes of many lay members, the general session is seen as a time when hundreds of people travel great distances, contribute thousands of hours, and spend money on travel expenses to listen to a lengthy multimedia report on what has already happened. After considering a few agenda items, the chaiman is given the task of consuming time--by calling for a succession of departmental reports -- until the nominating committee returns its report. It is not difficult to understand why the average uninvolved delegate is not only bored but frustrated because he/she is not able to offer some meaningful input into the affairs of the church.

The only excitement--and therefore the only feeling of accomplishment--is when someone becomes involved in a heated floor lHereafter, the initials SDA refers to the term
Seventh-day Adventist. 
debate or an administrator or department head is not reelected. Presumably the fired departmental director or administrator becomes the scapegoat, and this gives the delegates something to report to their respective churches, thus salvaging what appeared to be a wasted weekend.

How can such a situation be remedied? He nust do more than merely wring our hands and reiterate our wish that the noninating comittee not fire their denominational leaders during the constituency session. Currently some are suggesting a process of election by popular vote; others even express their desire that more than one name be placed on the ballot for various positions. This does not seen to be a viable solution. One hesitates to speculate where such a plan would lead; certainly it would take on the characteristics of a political convention.

As we consider the future, administrators should not be forced to the point of simply responding to popular opinion throughout their tems of service, especially in matters of theology or church discipline. This is particularly true when we remember that frequently down through history the majority has not only been uninfomed but has been wrong in its judgnent. Therefore, while the issue of leadership election must be an important part of the constitutency sessicn, the election process should take its proper role and not be overenphasized to the detriment of other important parts of the session.

This project is divided into three sections. It gives a brief explanation and historical background of constituency sessions in the Seventh-day Adventist Church. It then explores the 
findings of tivo surveys that sampled church members' current feelings toward constituency sessions.

Finally, the focus moves from the past to the future in an attempt to make suggestions on how the church organization can run more efficiently and effectively.

Fomat and Procedures Used in the Development and Implementation of the Testing Instrument

In cooperation with my major professor and the Andrews University Institute of Church llinistry, I desided that the evaluation instrument would be a survey sent to a sample of the delegates of the 1930 Upper Columbia and Idaho conferences' constituency sessions.

The questions were selected hecause they appeared to appropriately solicit the infomation necessary to evaluate the current feeling of constituents toward constituency sessions as well as give keys to how the sessions could possibly be improved. Revisions were made after consultation with the Institute of Church lilinistry, resulting in an acceptable instrument (see appendix for copy of the instrument).

Lists were acquired of all the names and addresses of the delegates. Through the process of a computer random survey, specific names were selected.

\section{Jpper Columbia Conference.}

The study focused on two representative conferences. The Upper Columbia Conference, organized in 1880, with a current membership of 16,359 members, represented large conferences (this conference has a number of institutional churches with a high 
concentration of Adventists). Geographically, the Upper Columbia Conference covers eastern Washington, the Idaho panhandle, and a portion of northern Oregon. ${ }^{1}$

The Upper Columbia Conference had 556 delegates at its 1980 session. It was decided that a sample of 240 of these should be surveyed to make the study valid. An additional tiventy-seven surveys were sent out for added validity. Of this total (267), 227 or $85 \%$ IJpper Columbia Conference surveys were eventually returned.

\section{Idaho}

The Idaho Conference, organized in 1907 and reorganized in 1930, with a current membership of 4,384 members, represented the smaller conferences (this conference has many of its churches in a rural setting.) Ceographically, the Idaho Conference covers most of the state of Idaho and a few eastern Oregon counties. ${ }^{2}$

The Idaho Conference had only 235 delegates for the 1930 conference constituency session. It was determined that 150 surveys should be mailed out, and an additional fifteen were sent for added validity. Of this number, a final total of 140 were returned.

\section{Samole}

The sample was divided into three categories: first by age--40 and above or below 40. This would help determine if there were differences of opinion in different age groups as well as

ISeventh-day Adventist Yearbook (Washington, D.C.: Review and Herald Pub. Assn., 1983), p. 235.

2Ibid., p. 233. 
possibly give an indication as to shat the future might hold with regard to how the younger delegates think.

The second category was professional status. The four basic representations surveyed included lay delegates (defined as those not paid hy the church), pastors of the local churches (delegates by virtue of their position), conference departmental personnel (their thinking was desired as they are elected during constituency sessions), and finally conference administrators (their viewpoint was wanted as they, too, are elected during the session and also are responsible for the planning of the session). Lastly, the surveys were numbered in such a way as to differentiate between respondents from the Upper Columbia Conference and the Idaho Conference.

\section{Obstacles}

There were some inherent problens that became increasingly apparent. Probably the greatest barrier to success was the fact that the events being evaluated, i.e., the 1930 conference constituency sessions, had transpired nearly two and one-half years before the survey was sent out. For one reason or another, sone people did not respond. Additionally, some of the delegates had moved.

A second problem was that, in addition to those who never responded, approximately 16 percent of the delegates sent back their surveys without completing them. Inasmuch as self-addressed envelopes were included to encourage a higher rate of return, it 
could have been that some mailed theirs back without wanting to be bothered with actually completing them. An equally plausible explanation could be that some of those not responding may not have attended, despite the fact that they were elected by their church and therefore appeared on the conference 1 ist. Some (10 percent) of the blank surveys which were returned did indicate that the persons had not attended.

A third possible reason for hesitancy was the matter of confidentiality. Despite the fact that it was clearly stated that the responses were confidential, a numbering system was used so that a record could be kept of those that did not respond initially so that a second and even a third nailing could be sent to them.

The fact that during the course of the study I moved to the Upper Columbia Conference in an administrative capacity may have intimidated some who were then afraid to respond candidly. This is suggested by the fact that one Upper Columbia Conference delegate anonymously sent his survey back stating it could not be confidential inasmuch as it was numbered. By the second or third mailing this person finally decided to respond. He did so only after cutting out the number on his survey, evidently satisfied that he could now respond candidly without fear of retribution.

\section{Procedure}

The basic procedure was simple. Following the development of the survey instrument and subsequent acceptance by the project director, the survey along with an accompanying letter and a return self-addressed envelope was sent to the 432 delegates. Their names 
were chosen by acceptable sampling procedures through the use of a computer-generated random-numbers program.

Each survey was given a three-digit number which corresponded to the delegate name. As the surveys were returned, they were checked off. A month later the same survey with a different cover letter and accompanying self-addressed stamped envelope was sent to those who had not responded to the first mailing.

After another month, a third and final mailing was rade following the same procedures. The returns are shown in table 1 . (See appendixes D, E, and F for copies of correspondence.) Table 2 shows in detail the number and percent of the respondents by group.

\section{TABLE 1}

\section{CONFERENCE CONSTITUENCY SESSION EVALUATION} SAYIPLE IDENIIFICATION AND SURVEY RETURN

\begin{tabular}{lcccccc}
\hline Conference & $\begin{array}{c}\text { Constituency } \\
\text { Delegates }\end{array}$ & $\begin{array}{c}\text { Random } \\
\text { Sample }\end{array}$ & $\begin{array}{c}\text { Additional } \\
\text { Sample }\end{array}$ & $\begin{array}{c}\text { Total } \\
\text { Surveyed }\end{array}$ & $\begin{array}{c}\text { Questionnaires } \\
\text { Returnet }\end{array}$ Puestionnate \\
\hline Upper Columbia & 556 & 240 & 27 & 267 & $227(858)$ & $182(80 \%)$ \\
Idaho & 235 & 150 & 15 & 165 & $140(85 \%)$ & $(18(84 \%)$ \\
All groups & 781 & 390 & 42 & 432 & $367(85 \%)$ & $300(31 \%)$ \\
\hline
\end{tabular}

*Fercentage of Questionnaires Returned. 
TABLE 2

DEIOGRAPHIC CHARACTERISTICS OF RESPONDENTS TO CONFERENCE CONSTITUENCY SESSION EVALUATION BY NUIIBER AND PERCENTAGE

\begin{tabular}{|c|c|c|c|c|c|}
\hline Lonference & $\begin{array}{l}\text { Lay } \\
\text { Delegates }\end{array}$ & Pasturs & $\begin{array}{c}\text { Jupartinental } \\
\text { Leaders }\end{array}$ & \multicolumn{2}{|c|}{ Adninistrators } \\
\hline Upper Columbi & & & & & \\
\hline $\begin{array}{l}40 \& \text { avove } \\
\text { below } 40\end{array}$ & $\begin{array}{rr}113 & (38.8 \%) \\
27 & (8.8 \%)\end{array}$ & $\begin{array}{ll}21 & (0.9 \%) \\
12 & (3.9 \%)\end{array}$ & $\begin{array}{ll}5 & (1.6 \%) \\
0 & \end{array}$ & 2 & $(.0 \%)$ \\
\hline Iuano & & & & & \\
\hline $\begin{array}{l}40 \text { \& above } \\
\text { Below } 40\end{array}$ & $\begin{array}{lr}84 & (27.0 \%) \\
21 & (0.9 \%)\end{array}$ & $\begin{array}{ll}4 & (1.3 \%) \\
4 & (1.3 \%)\end{array}$ & $\begin{array}{ll}3 & (.9 \%) \\
0 & \end{array}$ & $\begin{array}{l}3 \\
0\end{array}$ & $(.9 .0)$ \\
\hline
\end{tabular}


CHAPTER I I

\section{CONTEXT OF THE SDA CONFERENCE \\ CONSTITUENCY SESSIONS}

\section{Historical Background}

When in 1831 William lliller began preaching the message that Christ's return was imilinent, the furthest thing from his mind was beginning a new church.

They made no attempt to convert men to a sect or party in religion. llence they labored among all parties and sects, without interfering with their organization or discipline.

"In all my labors," said lliller, "I never had the desire or thought to establish any separate interest from that of existing denominations, or to benefit one at the expense of another. I thought to benefit all. Supposing that all Christians would rejoice in the prospect of Christ's coming, and that those who could not see as I did would not love any less those who should embrace this doctrine, I did not conceive there would ever be any necessity for separate meetings. . . The great majority of those who were converted under my labors united with the various existing churches."1

The escalating opposition to the Advent message became so bitter that, following the early disappointment in which Christ did not return at the predicted time, the Protestant churches in general began to excommunicate their members. Pastors offered the Adventists the alternative of renouncing their beliefs or losing their membership. While many acquiesced, thousands though

1Ellen G. White, The Great Controversy (lountain View, CA: Pacific Press Publishing Association, 1950), p. 375. 
perplexed and bewildered clung to their hope and were set adrift into a sea of uncertainty by their churches.

Under these circunstances the Adventist leaders reluctantly came to the conclusion that there was no fellowship for their people in the churches that were opposed to their faith and then Fitch, Storrs, Himes, Brown, Bates, Marsh, Snow, and others sounded the cry, "Come out of her, my people."1

Following the second great disappointment of 0ctober 22, 1344, in which Clirist was expected to return but again did not, the already critical situation among the Advent believers was exacerbated. Many returned to their former churches while others grouped together, generally by common theological views. Among those who were the forerunners of the Seventh-day Adventist Church, there was still strong opposition to the idea of fomally organizing a church. While it was true that Christ had failed to come when they had expected, certainly lle rould come very soon--perhaps in a matter of a few months, or a few years at most.

\section{Church Organization Emerges}

But as the 1850s came and went, it became increasingly imperative that some form of legal organization be developed.

The conducting of the affairs of a developing church, in a proper and orderly way, soon called for some sort of legal holding organizations for buildings anif property. Concerning such a move there was considerable opposition. As stated, some held that to have any holding organization would be going "back to Babylon." 2

$T_{\text {Arthur } W \text {. Spalding, Origin and History of Seventh-day }}$ Adventists, 4 vols. (Washington, D. C.: Revie!: and Herald Publishing Association, 1961), 1:89.

2LeRoy Edivin Froom, !lovement of Destiny (Washington, $D$. C.: Review and Herald Publishing Association, 1971), pp. 139-140. 
The pros and cons were openly debated through the inclusion of both the proposals and objectives in the church paper titled the Review \& Herald.

In the fall of 1860 the Review and Herald Publishing House, then the leading institution of Sabbath-keeping Adventists, became the first legally held institution. In 1861 "Seventh-day Adventist" was chosen as the official name of the church.

Ellen 'thite, a jifted author, speaker, and respected leader who played a leading role in the evolvement of the infant church, wrote during 1854 and 1855:

The church must flee to God's word, and become estahlisher upon gospel order which has been overlooked and neglected. This is indispensably necessary to bring the church into the unity of the faith.?

Order must be observed, and there must be union in maintaining order, or Satan will take the advantage. ${ }^{3}$

God is leading out a people, not a few separate individuals here and there, one believing this thing, another that. 4

The increasing complexity of the emerging church, due to the addition of nore members and pastors, was demanding attention. In 1859 it was suggested that each state have a yearly meeting to discuss plans for the upcoming year. ${ }^{5}$ This idea was accepted and 1:303-305.

Ispalding, Origin and History of Seventh-day Adventists,

2Ellen G. White, Supplement to Christian Experience and Views (Battle Creek: Review and Herald Publishing Association, 1354), pp. 18-19.

BEllen G. White, Testimonies for the Church, 9 vols. (Washington, D.C.: Review and Herald Publishing Association, 1948), $1: 210$.

\footnotetext{
4 Ibid., p. 207.

5 Janes White, "Yearly lleetings," Review and Herald, July 21,1859, p. 68 .
} 
put into operation in 1860 . These somewhat informal gatherings called for the laying of plans and later developed into constituted bodies with regularly elected delegates and leaders. The tide had turned. The die had been cast.

Not only did Ellen white give counsel stating the need for organization, she also gave instruction as to the form that organization should take.

\section{Four Forms of Church Organization}

There are four basic forms of church organization, any one of which might have been selected:

Episcopal -- the form of church government by bishops. Generally there are three orders of ministers in this form, i.e., bishops, priests, and deacons.

Papal -- the form of government with supreme authority vested in the pope. The hierarchial governing structure of this forms includes cardinals, archbishops, bishops, and priests. Local churches and individual members have authority in church administration.

Independent -- the form of church policy that makes the local church congregation supreme and final within its own domain. This form is often referred to as congregationalism.

Representative -- the form of organization that, while realizing the authority of the church is held by its membership, delegates that authority to administrative officers and boards.?

It is the fourth type (representative) of church government that Ellen White counseled the church to select. U1timately her counsel was accepted by the decision of the fledgling church. Later, in a manuscript read before the delegates at the 1909 General Conference session in Washington, D.C., she gave further

'Seventh-day Adventist Church llanual (Washington, D. C.: Review and Herald Publishing Association, 1967), p. 46. 
aivice on the types of delegates to be seiected for church

government conferences:

He (God) has so arranged matters that chosen men shall go as delegates to our conferences. These men are to be tried and proved. They are to be trustworthy men. The choosing of delegates to attend our conferences is an important matter. These men are to lay the plans that shall be followed in the advancement of the work; and therefore they are to be men of understanding, able to reason from cause to effect. 1

The Seventh-day Adventist Church ilanual defines the current

philosophy of church government as:

Representative -- the form of church government which recognizes that the authority in the church rests in the church membership, with executive responsibility delegated to representative bodies and officers for the governing of the church. This form of church government recognizes also the equality of the ordination of the entire ministry. The representative form of church government is that which prevails in the Seventh-day Adventist Church.?

The church's form of government is described in the

following manner:

Every nember of the church has a voice in choosing officers of the church. The church chooses the officers of the state conferences. Delegates chosen by the state conferences choose the officers of the union conferences; and delegates chosen by the union conferences choose the officers of the General Conference. By this arrangement, every conference, every institution, every church, and every individual, either directly or through representatives, has a voice in the election of the men who bear the chief responsibilities in the General Conference. 3

\section{Ifichigan -- The First Organized Conference}

In 1861 James $/$ hite addressed the conference assembled in Battle Creek and called for an effective state conference

Thite, Testimonies, 9:262.

2SDA Church lanual, p. 46.

3 White, Testimonies, $8: 236-237$. 
organization with delegates from local churches. The conference recommended that the churches in llichigan organize as a state conference to meet the following year.

On October 4, 1362, the Michigan delegation convened and elected a chaiman, secretary, and advisory committee of three. Additionally, seventeen organized churches were received into the conference by official vote. Except in the case of llichigan, however, the cause of organization merely marked time or regressed from the fall of 1360 to the fall of 1862.1

Under the influence of their leaders, members of the New York and Pennsylvania conferences voted against it. In Ohio, the ministers opposed the concept. In New England there was division among the members, and in the West there was indifference and some opposition.?

In September 1062 James thite wrote:

About all that has been done among the Seventh-day Adventists in relation to organization, is to silence the batteries of those who opposed it, and by dint of battle to succeed in forming the Publishing Association. And there the matter hangs, and we are not in as good condition to make a general strike for oryanization as we vere two and half years since, when the subject was first introduced. 3

The appeal to leadership by James White as well as remonstrances by the laity moved the cause along. ilinnesota, Iowa, Vemont, Illinois, Wisconsin, New York, and Ohio were organized $1: 306$

1Spalding, Origin and History of Seventh-day Adventists, 2 Ibid.

3 Ibid. 
shortly thereafter. ${ }^{1}$ The Ijper Columbia and Idaho conferences which have special significance in this thesis were organized in $1880^{2}$ and $1907^{3}$, respectively. Upon this foundation the current conference sessions (sometimes referred to as constituency sessions) were built.

\section{Contemporary Procedures}

Not unlike the first llichigan Conference session in 135?, conference sessions in the 1980s are still called to elect officers, receive newly organized churches into the conference organization, and discuss plans for the future.

The General Conference Working Policy for the Horth American Division outlines the objectives of a current session as follows:

In local conferences the churches are united in local conference organizations, appointing to the local conference session delegates who are duly authorized to represent the churches in the councils of the conferences. The conference session elects officers, grants credentials and licenses, adopts or changes the constitution, and transacts other business. One of its most important acts is the election of the executive committee, whose duty it is to function for the constituency during the interim between sessions. Thus vested in the committee is the delegated authority of all the churches within the conference. ${ }^{4}$

Great caution is observed to guarantee that the stated policy of a representative church government is practiced in actuality.

\section{Ibid.}

${ }^{2}$ Seventh-day Adventist Yearbook (Washington, D.C.: Review and Herald Pub. Assn., 1983), p. 235.

3ibid., , 0.233.

4 General Conference Working Policy (Washington, D. C.: Review and Herald Pub. Assn., 1975), p. 31, \#5. 
The following explicit guidelines are detailed under the section of Administrative Policies in the General Conference Working Policy:

a. Each church represented in the delegation at the session shall be empowered, through its delegation, to choose one nember of a committee to nominate standing committees.

b. In conferences with less than 10,000 members, one additional member shall be chosen by each church for each 500 members or major fraction thereof.

c. In conferences with more than 10,000 members, one additional member shall be chosen by each church for each full 500 members.

d. The persons thus selected, together with the leading union conference representative present, who shall act as chairman of this committee, shall be responsible for nominating a) 1 standing committees to be appointed by the session.

e. The chaiman of the nominating comittee at the local conference session shall be the president of the union or, in his absence, one designated by him shall be named to serve as chaiman. The nominating committee shall consist of from nine to fifteen nembers including the chaiman, except in conferences of more than 10,000 members, where up to six additional nembers may be added. This membership shall be balanced, as nearly as possible, between denominational workers and laymien representing various segments of the work and territories of the conference. Incumbent officers and departmental secretaries shall not be members of the nominating committee. To provide wider representation, incumbent members of the Conference Executive Comittee ordinarily shall not serve as members of the nominating committee.

$f$. The committee on Licenses and Credentials shall be composed of ordained ministers of experience. 1

So it can be seen that while the conplexity of the contemporary constituency session may have changed, the general purposes have not.

Inasmuch as these purposes are explicitly mandated in church policy, therefore giving little or no room for adaptation, this study will focus on what can be changed. Primarily the fornat and structure of the conference sessions will be analyzed.

$$
{ }^{1} \text { Ibid., p. } 67 .
$$


CHAPTER II I

\title{
SURVEY OF TWO SAYIPLE TRIENNIEL CONFERENCE CONSTITUEHCY SESSIOHS
}

\begin{abstract}
In an endeavor to evaluate the feelings of constituents toward the current constituency sessions, the need for the information obtained from a field survey became increasingly apparent. It was detemined that information should be sought covering reactions to the last session respecting such matters as levels of satisfaction, structure of the session, feelings about it, levels of comprehension regarding the proceedings, possible improvements, etc. The questionnaire employed the mode of the simple question with multiple-response options, an example being:

"How much of the proceedings do you think you understood?"
\end{abstract}

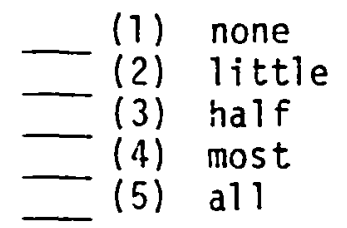

A final open-ended question made provision for comments from the respondees. ' While some of the survey questions would ask for very specific information, i.e., quality of public address system, the first question on the survey rould, in a sense, summarize much

1 See appendix $C$ for full text of the questionnaire. 
of what would follow as it sought to detemine the general satisfaction level.

\section{Satisfaction Level with Constituency Session}

The first question of the survey-and possibly the most significant one in that it represents the cumulative responses of the other eight questions--asked, "What was your level of satisfaction with the last conference constituency session?"

Delegates from both the small conference (Idaho) and the large conference (Upper Columbia) responded similarly (table 3). A combined total for "Very satisfied" and "Completely satisfied" was 42.9 percent for Idaho and 37.3 percent for Upper Columbia. Later data demonstrate that the delegates essentially want the opportunity for more involvement. It is inherent that the smaller the group the more opportunity there is for involvement. It is conceivable, then, that due to the smaller size of the Idaho constituent delegation, there was a somewhat higher level of involvement and thus a higher degree of satisfaction.

A rather discouraging finding is the lack of satisfaction in the below-40 age group as compared with the older group. This has particular implication for the future, assuming that the younger delegates will continue in leadership roles as the older ones move off the scene. Of those surveyed there were no administrators in the below-40 group. Inasmuch as all six of the conference administrators were surveyed, it can be seen that there were at that time no administrators under forty.

Another significant finding indicates that just because one derives his salary from the organization does not mean he is 
TABLE 3

RESPONSE TOTALS BY NUMBER AND PERCENTAGE TO CONFERENCE CONSTITUENCY SESSION EVALUATION BY ALL GROUPS, AGE, REPRESENTATION AND CONFERENCE SPECIFIC QUESTION 1

\begin{tabular}{|c|c|c|c|c|c|}
\hline \multirow{2}{*}{ Group } & \multicolumn{5}{|c|}{$\begin{array}{l}\text { What was your level of satisfaction with the last conference } \\
\text { constituency session? }\end{array}$} \\
\hline & $\begin{array}{l}\text { Not } \\
\text { Satisfied }\end{array}$ & $\begin{array}{l}\text { Somewhat } \\
\text { Sat isfied }\end{array}$ & $\begin{array}{l}\text { Very } \\
\text { Satisfied }\end{array}$ & $\begin{array}{l}\text { Completely } \\
\text { Satisfied }\end{array}$ & $\begin{array}{l}\text { No } \\
\text { Response }\end{array}$ \\
\hline Age & & & & & \\
\hline $\begin{array}{l}40 \& \text { above } \\
\text { Below } 40\end{array}$ & $\begin{array}{l}22(9.2 \%) \\
10(15.6 \%)\end{array}$ & $\begin{array}{r}101(42.1 \%) \\
35(54.7 \%)\end{array}$ & $\begin{array}{l}88(36.7 \%) \\
17(26.6 \%)\end{array}$ & $16 \quad(6.7 \%)$ & $\begin{array}{rr}13 & (5.4 \%) \\
2 & (3.1 \%)\end{array}$ \\
\hline Representation & & & & & \\
\hline $\begin{array}{l}\text { Lay delegate } \\
\text { Pastor } \\
\text { Dept leader } \\
\text { Administrator }\end{array}$ & $\begin{array}{rr}29 & (11.6 \%) \\
2 & (4.9 \%) \\
1 & (12.5 \%)\end{array}$ & $\begin{aligned} 109 & (43.6 \%) \\
22 & (53.6 \%) \\
4 & (50.0 \%) \\
1 & (20.0 \%)\end{aligned}$ & $\begin{array}{r}85(34.0 \%) \\
14(34.1 \%) \\
3(37.5 \%) \\
3(60.0 \%)\end{array}$ & $\begin{array}{rr}15 & (6.0 \%) \\
1 & (2.4 \%)\end{array}$ & $\begin{array}{r}12(4.8 \%) \\
2 \quad(4.9 \%) \\
1(20.0 \%)\end{array}$ \\
\hline $\begin{array}{l}\text { Conference } \\
\text { UCC } \\
\text { Idano }\end{array}$ & $\begin{array}{ll}21 & (11.3 \%) \\
11 & (9.2 \%)\end{array}$ & $\begin{array}{l}85 \\
51\end{array}\left(\begin{array}{l}45.9 \%) \\
42.8 \%)\end{array}\right.$ & $\begin{array}{l}63(34.0 \%) \\
42(35.3 \%)\end{array}$ & $\begin{array}{ll}7 & (3.8 \%) \\
9 & (7.6 \%)\end{array}$ & $\begin{array}{ll}9 & (4.9 \%) \\
6 & (5.0 \%)\end{array}$ \\
\hline All groups & y. $3 \%$ & $44.1 \%$ & $37.3 \%$ & $3.3 \%$ & $6.0 \%$ \\
\hline
\end{tabular}


therefore blindly satisfied. thile more than twice the percentage of Tay delegates as pastors were "Not satisfied", when the two most negative categories ("Hot satisfied" and Jomewhat satisfied") are added they total 55.2 percent for lay delegates compared to a similar 50.5 percent for pastors. What is possibly even nore significant is the fact that only 37.5 percent of the departmental men and 60 percent of the administrators were "Very satisfied." No administrators, who by virtue of their job descriptions planned the session, stated that they were "Completely satisfied."

It therefore becomes increasingly apparent that while those most closely involved with the organization and undertaking of the session are sonewhat more satisfied, there is almost universal dissatisfaction and therefore roon for improvenent.

The word that seens most descriptive of the feelings expressed in the open-ended questions is "frustration." One layperson wrote: "The powers that be have it all hammered out prior to the session. All they do is ruhber stamp it." Another frustrated young layperson wrote: "Lay delegates are only there to vote the decisions already made. Those on the payroll were not true delegates; vote your paycheck first."

To emphasize that this feeling is not that of the raity alone, one young pastor wrote: "Lack of real knowledge on the part of those participating--too much like a rubber-stanp process." Another pastor echoes this reaction with "It seemed so cut and dried." The perceptions of a sizable group seemed to be summarized in this last comment. 
Reasons for Satisfaction or Dissatisfaction

Question 2 is an obvious attempt to clarify the rationale behind the responses to question 1: "Were the following itens reasons why you responded as you did to question 1? Yes or no--(1) Arount of delegate participation, (2) Physical arrangement [e.g., seating, public address system, etc.], (3) Schedule of events, (4) Other [specify])." By giving some specific options to those surveyed, it was hoped to categorize some of the more general possibilities as to why they reacted to question number 1 as they did.

To simplify somewhat the interpretation and yet keep it. valid, a "Not satisfied" or "Sonewhat satisfied" designation in question 1 was grouped into the "Dissatisfied" category. A "Very satisfied" or "Completely satisfied" indication was categorized as "Satisfied." It is important to note that when all groups were combined, 37.1 percent saw "Amount of delegate participation" as a contributing factor to their dissatisfaction to question $I$ as opposed to 27.9 percent seeing it as contributing to their positive response (table 4 ).

The physical arrangements were a minor contributing factor either positively $(15.1$ percent) or negatively (13.1 percent). However it was more of a factor with the 'Jpper Columbia delegates with 16.7 percent dissatisfied.

The schedule of events was the one area that contributed positively to the satisfaction level of the delegates 127.3 percent). While this was true of all of the delegates as a group, it was not true of the below- 40 delegates. 
TABLE 4

RESPONSE TOTALS BY NUMBER AND PERCENTAGE TO CONFERENCE CONSTITUENCY SESSION EVALUATION BY ALL GROUPS, AGE, REPRESENTATION AND CONFERENCE SPECIFIC -- QUESTION 2

\begin{tabular}{|c|c|c|c|c|c|c|c|c|}
\hline \multirow{3}{*}{ Group } & \multicolumn{8}{|c|}{ Were the following items reasons why you responded as you did to question \#1? } \\
\hline & \multicolumn{2}{|c|}{$\begin{array}{l}\text { Amount of Delegate } \\
\text { Participation }\end{array}$} & \multicolumn{2}{|c|}{$\begin{array}{c}\text { Physical Arrangement } \\
\text { (seating, PA, etc.) }\end{array}$} & \multicolumn{2}{|c|}{ Schedule of Events } & \multicolumn{2}{|c|}{ Other } \\
\hline & Satisfied & Dissatisfied & Satisfied & Dissatisfied & Satisfied & Dissatisfied & Satisfied & Dissatisfied \\
\hline Age & & & & & & & & \\
\hline $\begin{array}{l}40 \text { \& above } \\
\text { Below } 40\end{array}$ & $\begin{array}{l}75(31.2 \%) \\
10(15.6 \%)\end{array}$ & $\begin{array}{l}83(34.5 \%) \\
30(46.8 \%)\end{array}$ & $\begin{aligned} 38 & (15.8 \%) \\
8 & (12.5 \%)\end{aligned}$ & $\begin{array}{l}29(12.0 \%) \\
11(17.1 \%)\end{array}$ & $\begin{array}{l}72(30.0 \%) \\
11(17.1 \%)\end{array}$ & $\begin{array}{l}36(15.0 \%) \\
16(25.0 \%)\end{array}$ & $\begin{array}{ll}8 & (3.3 \%) \\
2 & (3.1 \%)\end{array}$ & $\begin{array}{l}38(15.8 \%) \\
14(21.8 \%)\end{array}$ \\
\hline Representation & & & & & & & & \\
\hline $\begin{array}{l}\text { Lay delegate } \\
\text { Pastor } \\
\text { Dept leader } \\
\text { Administrator }\end{array}$ & $\begin{array}{l}70(28.0 \%) \\
11 \\
1(26.8 \%) \\
3(12.5 \%) \\
(60.0 \%)\end{array}$ & $\begin{array}{l}91(36.4 \%) \\
20(48.7 \%) \\
1(12.5 \%) \\
1(20.0 \%)\end{array}$ & $\begin{array}{r}40(16.0 \%) \\
4(9.7 \%) \\
2(40.0 \%)\end{array}$ & $\begin{array}{r}28(11.2 \%) \\
8(19.5 \%) \\
3(37.5 \%) \\
1(20.0 \%)\end{array}$ & $\begin{aligned} 67 & (26.8 \%) \\
11 & (26.8 \%) \\
2 & (25.0 \%) \\
3 & (60.0 \%)\end{aligned}$ & $\begin{aligned} 40 & (16.0 \%) \\
9 & (21.9 \%) \\
2 & (25.0 \%) \\
1 & (20.0 \%)\end{aligned}$ & $\begin{array}{ll}7 & (2.8 \%) \\
2 & (4.8 \%) \\
1 & (12.5 \%)\end{array}$ & $\begin{array}{r}42(16.8 \%) \\
8(19.5 \%) \\
2(25.0 \%)\end{array}$ \\
\hline $\begin{array}{l}\text { Conf erence } \\
\text { UCC } \\
\text { Idaho }\end{array}$ & $\begin{array}{l}50(27.0 \%) \\
35(29.4 \%)\end{array}$ & $\begin{array}{l}69(37.2 \%) \\
44(36.9 \%)\end{array}$ & $\begin{array}{l}24(12.9 \%) \\
22(18.4 \%)\end{array}$ & 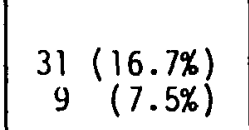 & $\begin{array}{l}46(24.8 \%) \\
37(31.0 \%)\end{array}$ & $\begin{array}{l}35(18.9 \%) \\
17(14.2 \%)\end{array}$ & $\begin{array}{ll}8 & (4.3 \%) \\
2 & (1.6 \%)\end{array}$ & $\begin{array}{l}35(18.9 \%) \\
17(14.2 \%)\end{array}$ \\
\hline All groups & $85(27.9 \%)$ & $113(37.1 \%)$ & $46(15.1 \%)$ & $40(13.1 \%)$ & $83(27.3 \%)$ & $52(17.1 \%)$ & $10(3.2 \%)$ & $52(17.1 \%)$ \\
\hline
\end{tabular}

Note: Satisfied - Shows the number of people who felt that the iten contributed to a more satisfying meeting. Dissatisfied - Shows the number of people who felt that the item contributed to a less satisfying meeting. 


$$
\text { Finaily, of tive "itier" gruul, a high } 5 \text { to } 1 \text { "atio of }
$$

negative contribution toberd the dissatisfaction level occurred.

\section{!liscellanenus Coments Regarding \\ Constibuency Survey}

Because of the suhjectivity of endeayoring to place the written comments into specific categories, the following information is generalized by approximate figures.

Approximately 25 percent of the Upper Columbia respondents and 15 percent of the Idaho respondents wrote in the "Other" category. of these, nine comments would be considered as positive. Six indicated that the general attitude, openness, and participation level were pusitive factors.

On the nttier side, approximately 20 percent of the delegates from Ipper ioluinbia dolegates and 15 percent from Idaho had coments regarding nejative factors relating to their satisfaction level.

While there was a wide variety of comments in this category, the vast majority would fall under tinree headings: (1) lack of factuai and sound information before and during the sessions, (2) lack of meaningful delegate input, and (3) the schedule. A broad sampling of comments is not included here because of the duplication of the similar responses to question 9.

Eighteen people comrented wit the lack of good factual information. Referring to the necd for better conmunication before the session, one below-40 Upper. Columbia pastor sajd, "Lack of prior input on agenda items. Discussion of issues needed in several regional meetings before constituency meetings." An 
ahove-40 Upper Columbia layperson felt that during the session there was also a lack of good information: "Some questions were answered evasively and not completely." That was seconded by another above-40 layperson from Upper Columbia: "Explanations for certain prograns were inadequate."

\section{Delegate Input in Sessions}

The major grouping would be what was perceived as a lack of meaningful delegate input. Approximately twenty Upper Columbia delegates addressed this issue and another fourteen from Idaho. Sample comments went like this. Fror Idaho a below-40 lay delegate wrote, "It seens the important decisions are pre-decided and we were asked to work on then only going through the motions." That sentiment was seconded by an above-40 lay delegate from the same conference who said, "Everything was decided before it was brought to the people."

On the general topic of lay input, an Upper Columbia above-40 delegate responded: "Church leaders are giving lip service only to lay participation!" Finally this frustrated lay delegate said, "The powers that be have it all hammered out prior to the session. All they do is rubber stamp it."

The first and third categories (Amount of delegate participation and schedule of events) dealt with the daily schedule. ilany delegates saw the problem as trying to accomplish too much in too little time. Five respondents from Idaho and nine from Upper Columbia wrote about this problem. A below-40 Upper Columbia lay delegate expressed his feelings succintly: "Too little 
time to perforn such an irmortant function." Anotier Upper Columbia above-40 lay delegate saw this issue tied to the preceding issue: "It seerns that everything is so rushed and that everything has been settled beforehand. You're just there to verify previous decisions." An Idaho above-40 lay delegate saw the available time being spent in the wrong way: "llost of the time is spent listening to reports."

\section{Credibility of Church Leadership}

Another very significant question was question 3 which deals with the credibility of church leadership: "To what extent did you feel the session was structured to be honest and open?" Again both conferences registered relatively parallel percentages under the various response categories (table 5).

One of the most obvious indications is that the group that least considered the session to be honest and open was the belo:4-40 group. It could be noted that the below-40 group included delegates who were growing up during the late 1950s and early 1970s. These are remembered as the anti-establishment years when it was in vogue for the young to distrust anyone over thirty years of age.

This same general group is beginning to assume lay church leadership at a time when must conference leaders are over forty years of age. Could it be possible that the church as a subculture is facing a sociological phenomenon not unlike that which the nation as a whole faced fifteen to twenty years ago?

Another skeptical group, more so than the lay delegates, was the pastor group. Some gap between the laity and clergy is 
TABLE 5

RESPONSE TOTALS BY NUIIBER AND PERCENTAGE TO CONFERENCE CONSTITUENCY SESSION EVALUATION BY ALL GROUPS, AGE, REPRESENTATION AND CONFERENCE SPECIFIC -- QUESTION 3

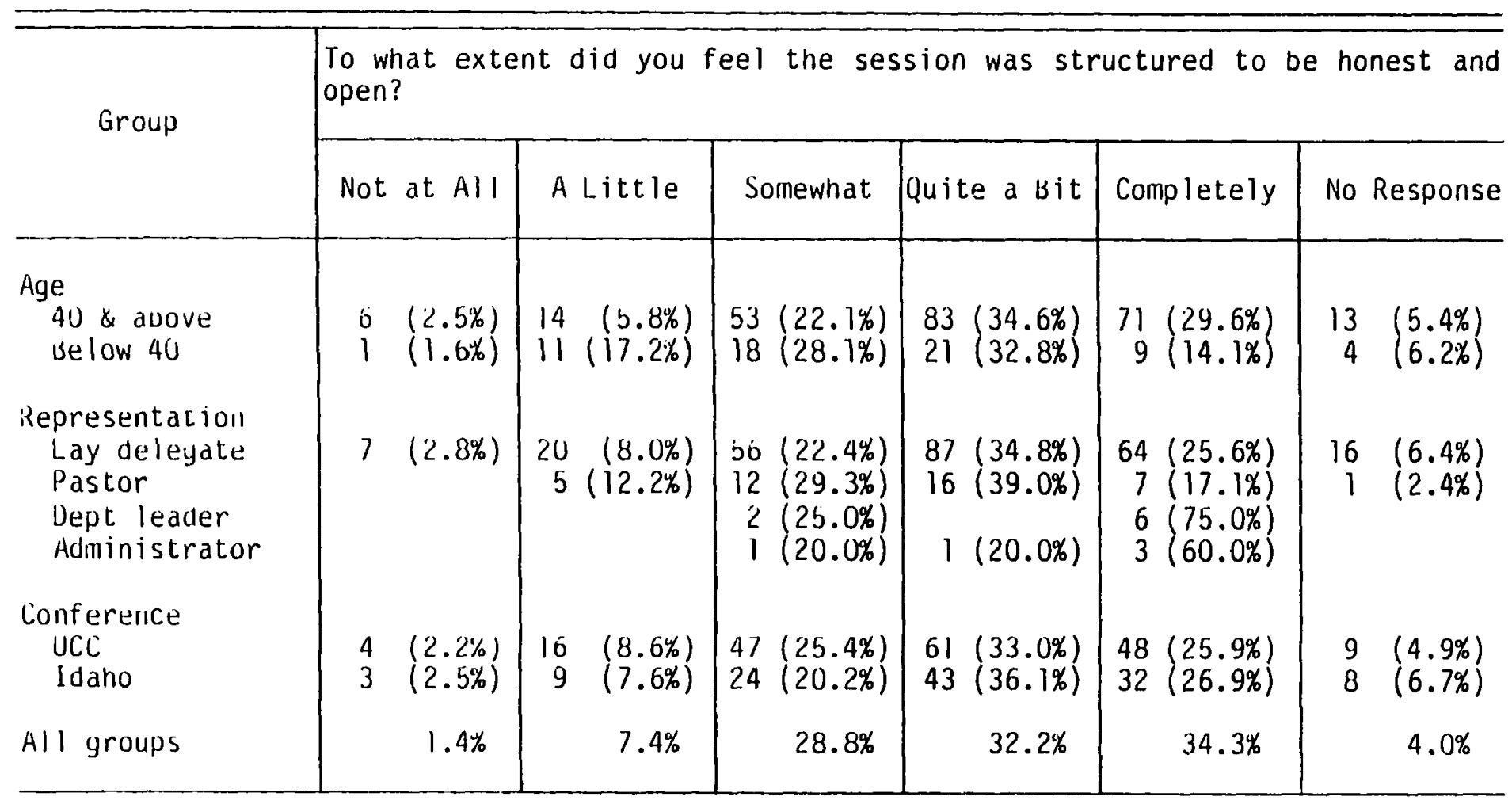


natural and expected. However, when the distrust pemieates even the professional organizational structure itself, it is distressing.

It is not surprising that 75 percent of the department leaders and 60 percent of the administrators felt that the session was completely honest and open. It is, however, interesting to note that one of the administrators felt that the session was only somewhat honest and open. It is possible that an awareness of a problem is the first step in improving any situation.

\section{Delejate Involvement}

The fourth question deals with the level of invoivement: "To what extent did you feel the structure of the session allowed for your meaninuful input in areas of plans, programs, and objectives for the next triennium?" Here delegates of the two conferences differed in their responses. Whereas Jpper Columbia has a combined total of 28.6 percent for the two top categories, Idaho had a combined total of 43.7 percent (table 5). The mere logistics involved where there are four times as many delegates from one conference as from the other make the opportunity unlikely for the same amount of input per delegate in the larger conference as that from delegates in the smaller conference.

The same frustration of the below-40 delegates is shown in the combined tutal for the tiro lower categories. "Not at all" and "A little" totaled 62.4 percent. The total for the above-40 delegates in the corresponding tivo lower categories was only 26.7 percent--a considerabiy more positive score. 
TABLE 6

RESPONSE TOTALS BY NUMABER AND PERCENTAGE TO CONFERENCE CONSTITUENCY SESSION EVALUATION BY ALL GROUPS, AGE, REPRESENTATION AND CONFERENCE SPECIFIC -- QUESTION 4

\begin{tabular}{|c|c|c|c|c|c|c|}
\hline \multirow[t]{2}{*}{ Group } & \multicolumn{6}{|c|}{$\begin{array}{l}\text { To what extent did you feel the structure of the session allowed for your } \\
\text { ineaningful input in areas of plans, programs and objectives for the next } \\
\text { triennium? }\end{array}$} \\
\hline & Not at All & A Little & Soinewhat & Quite a bit & A Lot & No Response \\
\hline \multicolumn{7}{|l|}{ Age } \\
\hline $\begin{array}{l}40 \& \text { above } \\
\text { Below } 40\end{array}$ & $\begin{array}{ll}22 & (9.2 \%) \\
20 & (31.2 \%)\end{array}$ & $\begin{array}{l}42(17.5 \%) \\
20(31.2 \%)\end{array}$ & $\begin{array}{l}64(26.7 \%) \\
14(21.9 \%)\end{array}$ & $\begin{array}{r}67(27.9 \%) \\
8(12.5 \%)\end{array}$ & $30(12.5 \%)$ & $\begin{aligned} 15 & (6.2 \%) \\
2 & (3.1 \%)\end{aligned}$ \\
\hline Representalion & & & & & & \\
\hline $\begin{array}{l}\text { Lay deleyate } \\
\text { Pastor } \\
\text { Dept leader } \\
\text { Adininistrator }\end{array}$ & $\begin{array}{r}34(13.6 \%) \\
8(19.3 \%)\end{array}$ & $\begin{array}{l}49(19.6 \%) \\
11(26.8 \%) \\
2(25.0 \%)\end{array}$ & 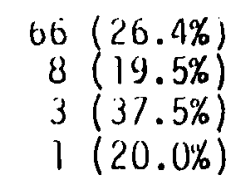 & $\begin{array}{r}62(24.8 \%) \\
10(24.4 \%) \\
2(25.0 \%) \\
1(20.0 \%)\end{array}$ & $\begin{array}{rr}24 & (9.6 \%) \\
3 & (7.3 \%) \\
1 & (12.5 \%) \\
2 & (40.0 \%)\end{array}$ & $\begin{array}{cc}15 & (6.0 \%) \\
1 & (2.4 \%) \\
1 & (20.0 \%)\end{array}$ \\
\hline $\begin{array}{l}\text { Conf erence } \\
\text { UcC } \\
\text { Idano }\end{array}$ & $\begin{array}{l}2 y(15.7 \%) \\
13(10.9 \%)\end{array}$ & $\begin{array}{l}38(20.5 \%) \\
24(20.2 \%)\end{array}$ & $\begin{array}{l}\text { bb }(29.7 \%) \\
23(19.3 \%)\end{array}$ & $\begin{array}{l}38 \\
37\end{array}\left(\begin{array}{l}20.5 \%) \\
31.1 \%)\end{array}\right.$ & $\begin{array}{l}\text { ib }(8.1 \%) \\
15(12.6 \%)\end{array}$ & $\begin{array}{r}10 \\
7\end{array} \quad\left(\begin{array}{l}5.4 \%) \\
5.9 \%)\end{array}\right.$ \\
\hline Al I yroups & $1<.5 \%$ & $20.1 \%$ & $2 ๖ .1 \%$ & $23.3 \%$ & $12.8 \%$ & $5.9 \%$ \\
\hline
\end{tabular}


Host of the delegates selected by the local churches are in the over -40 age group lof those surveyed the ratio was nearly 4 to 1). It is natural, then, that this same older group has a similar ratio of representation on the committees where much of the action takes place. Thus, younger delegates who may be attending the trienniel sessions for the first time have a very sinall chance of generating sufficient exposure to be placed on a committee. The feeling of being inerely a spectator is then exacerbated.

Another important point is that 60 percent of the administrators indicated that they believed the session allowed for much meaningful input--a definite difference of opinion from that expressed by the majority of their constituents.

\section{Confidence in Church Leadership}

Question 5 deals with the issue of whether or not the sessions had any impact on the delegates' confidence in leadership: "As a result of that session, your confidence in church leadership grew considerably, grew somewhat, stayed the same, diminished somewhat, or diminished consiterably." The largest percentage of respondents said that the session did not affect their level of confidence either positively or negatively. With all groups combined, 58.3 percent stated that it stayed the same.

Again, taking all groups together, 28.2 percent said that through the session their confidence had grown either "considerably" or "somewhat." Negative responses of "diminished somewhat" or "considerably" (table 7) were registered by 13.1 percent of the delegates. It is reassuring to note the movement is 
TABLE 7

RESPONSE TOTALS BY NUIBER AND PERCENTAGE TO CONFERENCE CONSTITUENCY SESSION EVALUATION BY ALL GROUPS, AGE, REPRESENTATION AND CONFERENCE SPECIFIC - QUESTION 5

\begin{tabular}{|c|c|c|c|c|c|c|}
\hline \multirow{2}{*}{ Group } & \multicolumn{6}{|c|}{ As a result of that session, your confidence in church leadership: } \\
\hline & $\begin{array}{c}\text { Grew } \\
\text { Considerably }\end{array}$ & $\begin{array}{c}\text { Grew } \\
\text { Somewhat }\end{array}$ & $\begin{array}{l}\text { Stayed the } \\
\text { Saine }\end{array}$ & $\begin{array}{l}\text { Diminished } \\
\text { Somewhat }\end{array}$ & $\begin{array}{c}\text { Diminished } \\
\text { Considerably }\end{array}$ & No Response \\
\hline $\begin{array}{l}\text { Age } \\
40 \& \text { above } \\
\text { Below } 40\end{array}$ & $\begin{array}{r}28(11.7 \%) \\
2(3.1 \%)\end{array}$ & $\begin{array}{r}35(14.9 \%) \\
8(12.5 \%)\end{array}$ & $\begin{array}{r}137(57.1 \%) \\
38(59.4 \%)\end{array}$ & $\begin{array}{rr}21 & (8.7 \%) \\
9 & (14.1 \%)\end{array}$ & $\begin{array}{ll}7 & (2.9 \%) \\
4 & (6.2 \%)\end{array}$ & $\begin{aligned} 12 & (5.0 \%) \\
3 & (4.7 \%)\end{aligned}$ \\
\hline $\begin{array}{l}\text { Representacion } \\
\text { Lay delegate } \\
\text { Pastor } \\
\text { Dept leader } \\
\text { Adininistrator }\end{array}$ & $\begin{array}{cc}26 & (10.4 \%) \\
1 & (2.4 \%) \\
2 & (25.0 \%) \\
1 & (20.0 \%)\end{array}$ & $\begin{aligned} 38 & (15.2 \%) \\
5 & (12.2 \%)\end{aligned}$ & $\begin{aligned} 137 & (54.8 \%) \\
31 & (75.6 \%) \\
4 & (50.0 \%) \\
3 & (60.0 \%)\end{aligned}$ & $\begin{array}{rr}26 & (10.4 \%) \\
2 & (4.9 \%) \\
2 & (25.0 \%)\end{array}$ & $\begin{aligned} 10 & (4.0 \%) \\
1 & (2.4 \%)\end{aligned}$ & $\begin{array}{cc}13 & (5.2 \%) \\
1 & (2.4 \%) \\
1 & (20.0 \%)\end{array}$ \\
\hline $\begin{array}{l}\text { Conferelice } \\
\text { UCi } \\
\text { Idaho }\end{array}$ & $\begin{array}{l}13(7.0 \%) \\
17(14.3 \%)\end{array}$ & $\begin{array}{l}2 y(15.7 \%) \\
14(11.8 \%)\end{array}$ & $\begin{array}{r}108(58.4 \%) \\
67(56.3 \%)\end{array}$ & $\begin{array}{ll}20 & (10.8 \%) \\
10 & (8.4 \%)\end{array}$ & $\begin{array}{ll}7 & (3.8 \%) \\
4 & (3.4 \%)\end{array}$ & $\begin{array}{ll}8 & (4.3 \%) \\
7 & (5.9 \%)\end{array}$ \\
\hline All groups & $17.9 \%$ & $10.3 \%$ & $58.9 \%$ & $10.3 \%$ & $2.8 \%$ & $5.9 \%$ \\
\hline
\end{tabular}


in the right direction by a 15.1 percent margin. Unfortunately, the below-40 delegates were less satisfied. Then combining the same two categories, this group indicated that 15.6 percent grew "considerably" or "somewhat" while 20.3 percent "diminished considerably" or "sonewhat"--not a good indicator for the future unless the general trend can be altered.

\section{Improving Constituency Sessions}

Question 6: "If you could improve the next session, which of the following things would you do? Put 1 by the most important, 2 by the next most important, etc." was an endeavor to see what the delegates perceived as priorities for making the next session better. The calculations were based on their first through third choices and weighted accordingly.

When all categories were tallied, the areas given the highest priority from the delegates were numbers 2,7 , and 3 , respectively (table 8). Statement 2--"Involve more delegates in committee work"--deals with delegation and cooperation. Statement 7--"Give more opportunity for input into plans and objectives of conference"--deals with the setting of clearly defined goals. Finally, statement 3--"Devise another way of electing conference leadership"--deals with accountability. These three priorities, not coincidentally, have been suggested as the three God-given principles of management as noted in chapter 6 .

In looking more closely at option 2, "Involving more delegates in committee work," it is obvious that all categories see this need. The need for more involvement or working together holds 
TABLE 8

RESPONSE TOTALS BY WEIGHTED NUMBERS TO CONFERENCE CONSTITUENCY SESSION EVALUATION BY ALL GROUPS, AGE, REPRESENTATION AND CONFERENCE SPECIFIC -. QUESTION 6

\begin{tabular}{|c|c|c|c|c|c|c|c|c|}
\hline \multirow[b]{2}{*}{ Group } & \multicolumn{8}{|c|}{$\begin{array}{l}\text { If you could improve the next session, which of the following things would you do? } \\
\text { Put } 1 \text { by the most important, } 2 \text { by the next most important, etc. }{ }^{\star}\end{array}$} \\
\hline & 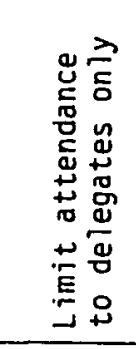 & 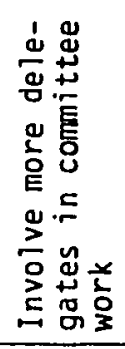 & 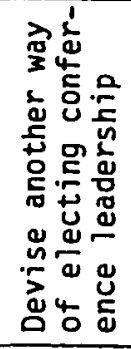 & 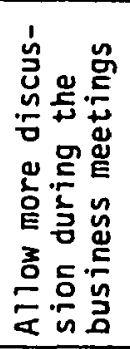 & 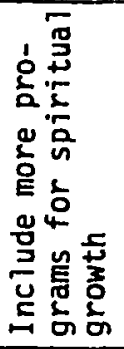 & 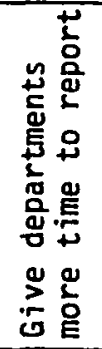 & 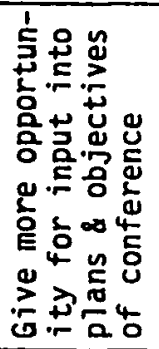 & 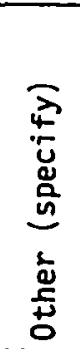 \\
\hline \multicolumn{9}{|l|}{ Age } \\
\hline $\begin{array}{l}40 \text { \& above } \\
\text { Below } 40\end{array}$ & $\begin{array}{l}34 \\
16\end{array}$ & $\begin{array}{r}196 \\
66\end{array}$ & $\begin{array}{l}89 \\
46\end{array}$ & $\begin{array}{l}76 \\
38\end{array}$ & $\begin{array}{l}86 \\
13\end{array}$ & $\begin{array}{r}23 \\
6\end{array}$ & $\begin{array}{r}156 \\
72\end{array}$ & $\begin{array}{l}33 \\
12\end{array}$ \\
\hline \multicolumn{9}{|l|}{ Representation } \\
\hline $\begin{array}{l}\text { Lay delegate } \\
\text { Pastor } \\
\text { Dept leader } \\
\text { Administrator }\end{array}$ & $\begin{array}{r}42 \\
8\end{array}$ & $\begin{array}{r}220 \\
35 \\
4 \\
3\end{array}$ & $\begin{array}{r}115 \\
14 \\
6\end{array}$ & $\begin{array}{r}92 \\
18 \\
4\end{array}$ & $\begin{array}{r}83 \\
11 \\
3 \\
2\end{array}$ & 29 & $\begin{array}{r}176 \\
41 \\
5 \\
6\end{array}$ & $\begin{array}{l}35 \\
10\end{array}$ \\
\hline $\begin{array}{l}\text { Conf erence } \\
\text { UCC } \\
\text { Idaho }\end{array}$ & $\begin{array}{l}38 \\
12\end{array}$ & $\begin{array}{l}155 \\
107\end{array}$ & $\begin{array}{l}77 \\
58\end{array}$ & $\begin{array}{l}53 \\
61\end{array}$ & $\begin{array}{l}58 \\
41\end{array}$ & $\begin{array}{l}13 \\
16\end{array}$ & $\begin{array}{r}152 \\
76\end{array}$ & $\begin{array}{l}28 \\
17\end{array}$ \\
\hline All groups & 50 & 262 & 135 & 114 & 99 & 29 & 228 & 45 \\
\hline
\end{tabular}

*Only top three choices ranked are included.

\#Total numbers represent a weighted response. Each \#1 was weighted 3 , each \#2 was weighted 2 , and each \#3 was weighted 1. 
true of the lay delegate, pastor, and department representatives (table 8). Unfortunately, only one administrator saw this as a top priority. If realizing a problem is the first step toward a solution, it is possible that administrators need to be made more aware of their constituents' feelings if progress is to be made in this high priority item.

A close second in the priority ratings was item 7: "Give more opportunity for input into plans and objectives of conference." In fact, the under-40 group saw this as more important than item 2. It should be of some encouragement to them to note that the conference administrators alsn saw this as a high priority. In reality these two areas of involvement and objective setting are closely related.

The third priority of all groups was item 3, "Devise another way of electing conference leadership," dealing with accountability of the church leadership. This specific area is considered below in greater detail.

\section{Comprehension Level of Delegates}

Question 7 dealt with the general comprehension level of what was transpiring during the session: "How much of the proceedings sid you understan!?"

When all delegate groups were considered together, 39.9 percent said they understood all of the proceedings and an additional 4.5 .4 percent felt they understood most of what went on for a total of 85.3 percent (table 9). It is not surprising that the closer the individual was involved with the administration of 
TABLE 9

RESPONSE TOTALS BY NUMBER AND PERCENTAGE TO CONFERENCE CONSTITUENCY SESSION EVALUATION BY ALL GROUPS, AGE, REPRESENTATION AND CONFERENCE SPECIFIC -- QUESTION 7

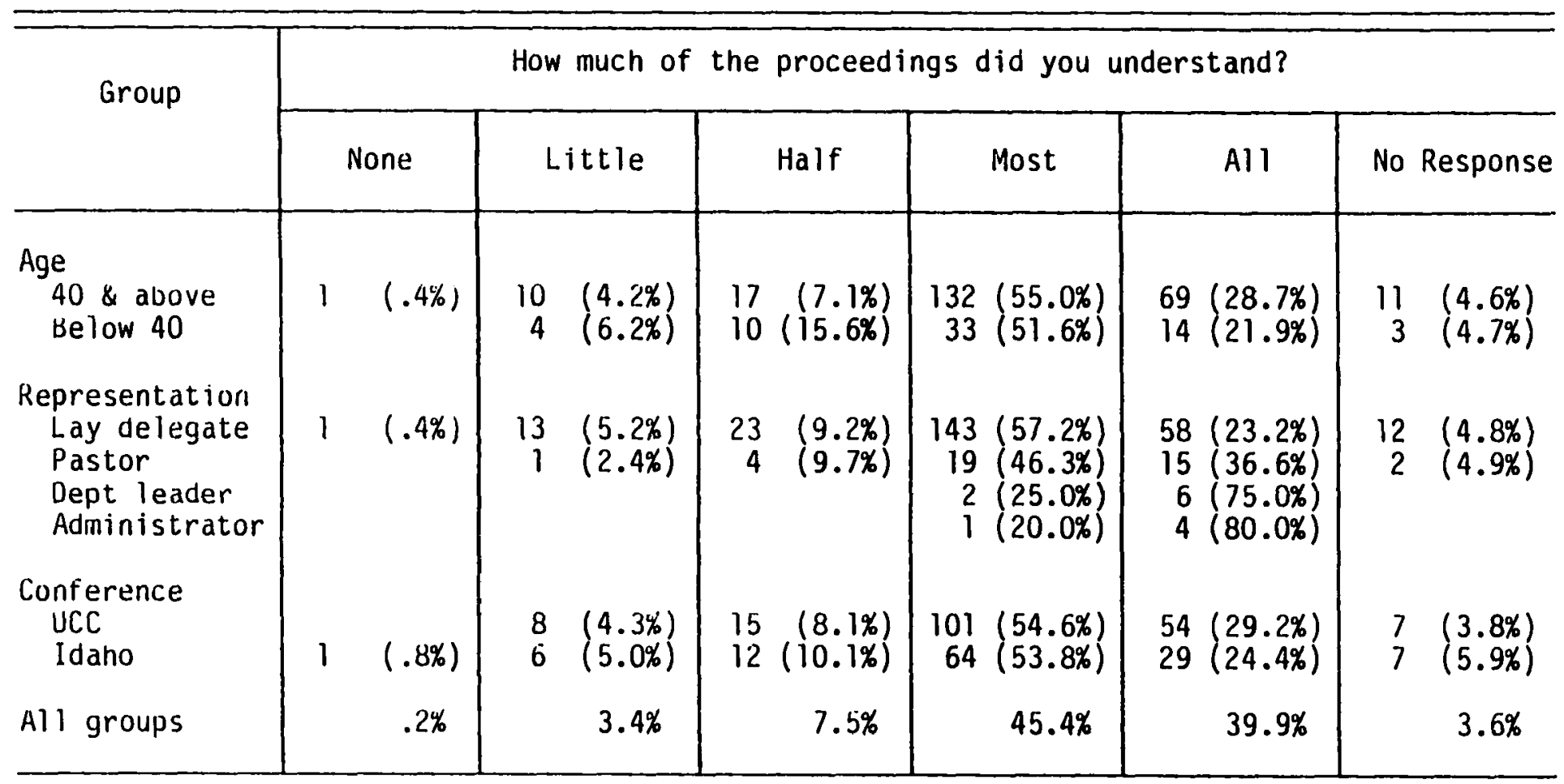


the conference :lork, the more he understood. Only 23.1 percent of the lay delegates said they had complete understanding. That figure went to 75.0 percent in the departmental leadership while 80.0 percent of the administrators felt they understood all of the proceedings.

\section{Purpose of Constituency jession}

Question $\delta$, "What is the purpose of constituency sessions? Put 1 by the most important purpose, 2 by the second most important, etc.," was handled in the same nanner as number 6 , a similar type question of priority ranking. The first through third choices were weighted and counted accordingly. When all groups were combined, the top priority was option 3: "Give input to leadership on goals, plans, ideas for future" (table 10). As in question 6 , this indicates that the membership at large should be involved. This question is further documented below.

The second most important reason for having a constituency session, according to all groups, is to elect church leadership, option 1. It is not surprising that the administrators saw this as a priority. They realize that if they are not reelected they will not be involved in carrying out the plans for the future no matter how good the plans right be.

It is likewise a high priority with the pastors as they are impacted directly when there is a change in leadership.

Future P1 ans and Objectives

The third priority of all groups was 4: "Hear reports of future plans and objectives." Two points should be noted here. 
TABLE 10
RESPONSE TOTALS BY WEIGHTED NUMBERS TO CONFERENCE CONSTITUENCY SESSION EVALUATION BY ALL GROUPS, AGE, REPRESENTATION AND CONFERENCE SPECIFIC -- QUESTION 8

\begin{tabular}{|c|c|c|c|c|c|}
\hline \multirow[b]{2}{*}{ Group } & \multicolumn{5}{|c|}{$\begin{array}{l}\text { What is the purpose of constituency sessions? Put } 1 \\
\text { by the most important purpose, } 2 \text { by the second most } \\
\text { important, etc.*\# }\end{array}$} \\
\hline & 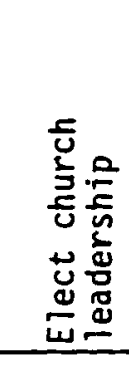 & 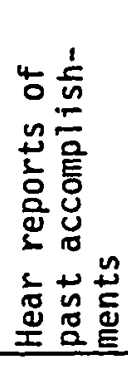 & 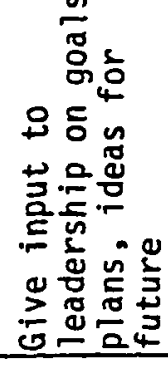 & 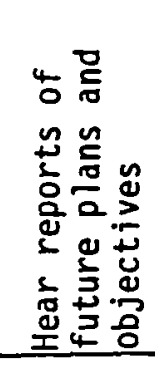 & 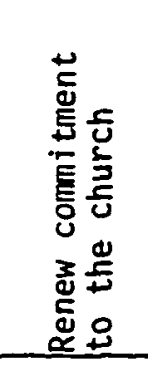 \\
\hline $\begin{array}{l}\text { Age } \\
40 \text { \& above } \\
\text { Below } 40\end{array}$ & $\begin{array}{r}248 \\
80\end{array}$ & $\begin{array}{l}48 \\
15\end{array}$ & $\begin{array}{r}244 \\
92\end{array}$ & $\begin{array}{r}138 \\
53\end{array}$ & $\begin{array}{l}83 \\
23\end{array}$ \\
\hline $\begin{array}{l}\text { Representation } \\
\text { Lay delegate } \\
\text { Pastor } \\
\text { Dept leader } \\
\text { Administrator }\end{array}$ & $\begin{array}{r}258 \\
59 \\
7 \\
4\end{array}$ & $\begin{array}{r}48 \\
12 \\
3\end{array}$ & $\begin{array}{r}273 \\
49 \\
10 \\
4\end{array}$ & $\begin{array}{r}168 \\
14 \\
5 \\
4\end{array}$ & $\begin{array}{r}82 \\
16 \\
8\end{array}$ \\
\hline $\begin{array}{l}\text { Conference } \\
\text { UCC } \\
\text { Idaho }\end{array}$ & $\begin{array}{l}209 \\
119\end{array}$ & $\begin{array}{l}28 \\
35\end{array}$ & $\begin{array}{l}209 \\
127\end{array}$ & $\begin{array}{r}117 \\
74\end{array}$ & $\begin{array}{l}70 \\
36\end{array}$ \\
\hline All groups & 328 & 63 & 336 & 191 & 106 \\
\hline
\end{tabular}

*Only top three ranked are included. \#Total numbers represent a weighted response. Each \#1 was weighted 3, each \#2 was weighted 2 , and each \#3 was weighted 1. 
The first one is encouraging. In some questions there were significant gaps between responses of the administration and those of the laity. However, in this important area of the purpose of the constituency session which somewhat underlies all the others, the administration indicated the three top purposes to be the same as those chosen by the delegates--not in the exact order but the saine three purposes.

The second point is the emphasis given by the delegates to future plans and goals--options 3 and 4 . Traditionally much emphasis has been given to the accomplishments of the past tricanium, but in this survey delegates rated 2 and 5 lower (options dealing with the past and commitment). This possibly suggests that a philosophical change is indicated in the planning structure of the sessions which is addressed further in chapters 4 and 5 .

One additional point of less importance but worth mentioning is the lack of interest in option 5: "Renew commitment to the church." This correlates with the coments under question 9--the heading of more/less spiritual emphasis in both this chapter and chapter 5.

Surmiary

It appears that a significant percentage of delegates come to a session feeling tha: they have not received the information they want and need to make intelligent decisions. When they do receive the material, they comment that it is given to then too fast to properly assimilate before coming to a vote. This spawns 
the feeling of merely "rubber stamping" prior decisions of the conference leadership. It is therefore logical that frustration would be experienced by the delegates who want some meaningful input into the organizational and planning phases of their church.

\section{Suggestions for ilore Effective lleetings}

Question 9 was open-ended: "What other suggestions would you like to make that would make the upcoming constituency session more effective and efficient?" of the 300 usable surveys returned, 164 (54.7 percent) responded to this question. The respondents had to show additional incentive in order to take time to formulate their thoughts and write then down as opposed to merely checking an answer as in the preceding eight questions. The large number that responded indicates the interest of the membership in this area of church government.

The responses fell into eight general areas. The very nature of this question made it difficult to categorize all the responses as some fell into more than one area. For that reason, the figures given in this section are approximate.

The eight categories are as follows:

$$
\begin{aligned}
& \text { Delegate input and lay involvement } \\
& \text { Representation } \\
& \text { Prior information and work } \\
& \text { Better/different organization } \\
& \text { Election process } \\
& \text { Reporting honestly/factually } \\
& \text { Spiritual emphasis more/less } \\
& \text { Commendation/confidence/satisfaction }
\end{aligned}
$$

A sampling of comments from these eight categories will give additional understanding of the feelings being expressed by the constituents. 
Delegate Input and Lay Involvement

In this category approximately twenty Upper Columbia and sixteen Idaho delegates responded.

One above-40 1ayman from Ipper Columbia attached a letter to his comments for question 9:

The constituency meeting which I attended at Spangle, Washington, was completely unsatisfactory. It was obvious from the procedures followed and the planned agenda that it was a "canned program" with no opportunity for input or dialogue. I felt it was a waste of my time to attend. Decisions had already been arrived at before arrival at Spokane. The procedures surely did not speak to any democratic exchange. It was disappointing and upsetting to say the least.

Another above-40 lay delegate responded more succinctiy:

I would suggest that since all issues have basically already been decided, that you not waste the delegates' time, which I am sure you would probably do if it were not requested by law. Vote by more ballots and you could get the required "yes" votes to satisfy the requirements. I would never again waste my time going to one of these meetings. They are an insult to the intelligence of even the non-thinking person.

Several used a rather succinct, yet descriptive, evaluation of the proceedings. A belo:v-40 lay delegate used the term "rubber stamp" to express his frustration:

In my estimation the constituency meeting is little more than a rubber stamp. Everything has been decided and passed or put in motion beforehand. The meeting is only a formality. The lay people have no real say in the operation of the local or union conference.

Another above-40 Upper Columbia 1 ay delegate added, "Seemed to be already cut and dried."

The same feeling was expressed by an Idaho lay delegate:

"Everyone I have ever spoken to that has been a lay delegate at a constituency meeting has felt that their presence was just a formality and that all decisions had already been made." 
One Ida!no delegate felt he was speaking for more delegates than just himself and that the situation had existed for some time. He said, "Hould be so much better if most things weren't 'cut and dried' before the delegates even arrive! Have heard many delegates remark about this."

Finally, this Idaho below-40 lay delegate echoes the prior sentiments but additionally asks a very good question:

This was my first time attending--everything seened so cut and dried--all we did was ratify what the leadership proposed. Are any lay people involved in pre-comnittee work to study all alternatives before arriving at a suggested course of action?

Rather than merely complaining, he suggests a solution:

Possibly two different approaches to a problem should be reviewed by the membership; have discussion giving pros and cons and then have a vote instead of only hearing one approach to the plans for the coming years.

A natural description of the style of leadership employed, if the conference administration is, in fact, not listening, was described by this under-40 Idahoan: "Listen to the members of the churches and cease to be dictatorial."

\section{Representation}

Closely related to the cry for responsive leadership was a concern for the type of representation sent to and heard during the session. Approximately ten Upper Columbia delegates and another nine from Idaho addressed this issue.

Traditionally all pastors are able to vote at constituency sessions and are automatically delegates-at-large. One Idaho over-40 lay delegate questioned the wisdom of this procedure: "Too many conference workers as delegates-at-1arge." One under-40 Idaho 
layman felt that the prohlem was a bit more videspread than just domination by preachers. He complained that representation was not sufficiently distributed: "We need more comunication with constituency and be able to listen to some laity instead of just doctors and preachers. llost of these kinds are supported by the rest of us anyway."

Closely related and even broader was the conment of an over-40 Idahoan who said, "Let someone besides the rich have something to say about what goes on. If one is just a common person he is treated like a peon." And an over-40 delegate from Upper Columbia apparently believes the problem is not isolated in the Idaho Conference: ":loney seems to play too important a part in the power structure of who gets on committees."

An additional concern five delegates mentioned in this area was block voting. Some wisdon was shown by one above-10 Idaho lay delegate who said, "Avoid any 'block delegations' that may try to steamroll some local faction rather than have truly a conference-wide program with a total growth picture in mind."

This was seconded by an Idaho department leader: "Devise a method to halt the tendency for some churches to have a block of delegates to 'push' their personal or local opinions or railroad the ir ideas."

Another Idaho over-nj lay delegate made a valid observation that is further addressed in chapter 4. He said, "One or two delegates from each church is sufficient. Should be a smaller more working session." One cannot help but sympathize with a a frustrated Upper Columbia delegate who commented: 
Our lay people want to be involved: The greatest contribution would be to create brainstorm sessions or planning sessions that would keep them occupied and make them feel like what they were doing was important. Nothing makes me feel more left out and used than to listen to boring reports while the action is somewhere else.

\section{Prior Work and Information}

A number of the responses to question 9 dealt with the area of pre-meeting work and communication. An under-40 IJpper Columbia lay delegate made two observations on this point: "Consider regional information mectings in advance of the constituency session. Provide delegates with advance written information so intelligent decisions can be made."

One Upper Columbia lay delegate expressed what others felt: "ilore communication before meetings as to problem areas, potential problens, and possible solutions. Too much time is spent discussing situations that should have been taken care of beforehand."

Another over-40 1 ay delegate from Upper Columbia expressed a desire to be involved but felt some frustration in his endeavor to be prepared: "Send out advance infomation on all aspects of the meeting--our goals, objectives, offices to be filled, etc., so that delegates can better prepare themselves to he an active part of our church program." An Iritio lay delegate expressed his feelings similarly: "Less time delegated to the audiovisual presentations and more data and time to discuss the programs and policies."

\section{Better/Different Organization}

llany of the miscellaneous suggestions were grouped under this general topic with approximately twenty responding from Upper 
Columbia and eight from Idaho. Inasmuch as the coments ranged from having padded seats to a comment on the "boring reports," it would be impractical to endeavor to address each concern. A sample, however, is included.

Several commented on deliberation on the floor. Ine IJpper Columbia pastor was definitely disturbed by the waste of time which he attributed to technicalities:

What has been very distressing to me is all the point of order problems. This consumes tremendous amounts of time--also the hashing through the rewording of changes in constitution or other definition - type matters. In this the whole meaningfulness of the session is disrupted. I don't know how this can be more effectively handled, but somehow it should be.

Another Upper Columbia pastor expressed similar feelings:

I feel that there was too much argument last time about parliamentary procedure. It was the first time in my 2.5 years of ministerial experience that a parliamentarian was used. I believe in doing things decently and in order, but I thought it spoiled the theme of the program. It showed to me that there were those there that were more interested in the parliamentary law than the reason why we were there--doing the Lord's business.

The recent innovation of having a multimedia presentation rather than lengthy departmental reports has been introduced as part of the program. Some question the validity of even this--as expressed by the following comments.

An Upper Columbia Conference below-10 lay delegate suggested: "Less time delegated to the audiovisual presentation and nore data and time to discuss the programs and policies." Another Upper Columbia delegate attached a letter. It said in part:

Every session it seens that someone seems to feel that we need to be entertained, so we have a picture show or something that takes up time and must cost something to produce. I would suggest that you take that time to take care of the business 
that needs to be done. These meetings are very long and the sooner they are finished everyone can go home.

Two under-40 people from the Idaho conference made statements about the voting process. One suggested the use of "secret ballot." That was echoed by another suggestion to "make the voting process more private". This complaint is understandable, inasmuch as some of the delegates are on conference payroll, and the present procedure could be perceived as a conflict of interest.

\section{Election Process}

Approximately fifteen people from the Upper Columbia Conference expressed their feelings on the election process while only three from Idaho felt it was important enough to merit their comments. One under-40 lay delegate from Ipper Columbia had two suggestions pertaining to beginning the election process before the actual session: "Have names of the individuals to be elected mailed to the delegates a month or so in advance so no rushed decisions are made. liave a committee sork on names before the session."

One person thought it would add spice if there were some variety in the selection process:

I can't help but wonder how inuch more interesting life would be if we had tivo candidates declare for conference president. They presented a proposal for their emphasis of leadership in the conference and the entire churches llay members) and administrators and pastors all had one vote per person and could choose between instead of this 'election by com:littee' for all intents and purposes.

This Upper Columbia department leader felt that there should be more delegate input into the election of the officers but less into his own office. 
I believe we need to find some way that the delegates can have more say in the session for election of conference officers and not a few hotheads who always get thenselves on the nominating committee. I further feel only conference administration and conference committee should be selected by the delegates. The election of department leadership should be done by conference committee.

Another departmental person from Upper Columbia Conference expressed a valid concern from his perspective:

If a major function of a constituency meeting is to elect department personnel, there should be an evaluation process-one that is directed to the perfomance of specific objectives as agreed to by all parties. An instrument could be developed tilat would measure the effectiveness of personnel, and personnel should know ahead of time what their shortcomings are and be given time to improve. As it stands now, a departmental leader is evaluated without himself being aware of the criterion used. And in many instances, the presifent is not even present during much or all of the discussion in nominating comnittee.

Still another delegate speaks to the issue that a person can either be reelected or dropped without valid reason: "In the past it was cut and dried before the committee even met. The person involved as director of a department was either railroaded in or out, according to one or two persons on the committee."

So it becomes increasingly obvious that there are feelings of inadequecies in the current system being experienced by both those electing and those being elected.

\section{Reporting Ilonestly/Factually}

Five people from Idaho and another four from Upper Columbia conmented on either the perceived honesty and odenness of the reports and responses or the completeness of the facts.

An IJper Columbia lay delegate touched on the frustrations of those planning constituency sessions in regard to how much information is enough: 
The reports could be shortened--even left out. They seen to be a last opportunity for a department man to impress the constituency. There are reports that are really for the purpose of informing--but those that are are not very obvious. It just may not be possible, but someone has to discover some way of explaining the financial report without everyone but the auditors and treasurer getting totally lost and confused.

A good observation by a lay delegate from Idaho addresses the whole area of accountability, or lack thereof: "Devise a method for evaluating outcomes of objectives set in previous triennial constituency meetings as part of reporting process."

A slightly different concern but definitely a valid one deals with the delegates' responsibility in the area of reporting. This is expressed by one Idaho lay delegate:

The thing which I felt and feel as a church member is that delegates may not be reporting to their own constituencies. Therefore the nembers who do not attend do not feel included in the decisions, recommendations, etc. At least half of the churcies represented where I sat on committee said they never hear a report from their conference representative. I am from the Long Creek church and not once in the past ten years has our conference delegate reported to the church as a whole.

\section{Spiritual Emphasis}

Four delegates from Upper Columbia and three from Idaho felt that the constituency session should give more spiritual emphasis as opposed to merely being a business session. One over-40 lay delegate expresses what must certainly represent a minority feeling when he states, "We need a good semon on oneness and the purity of this $30 A$ message and the writing of Ellen $G$. White before any meeting is started. It must be strong, straightforward, without any excuses."

A similar opinion was expressed by a pastor in Upper Columbia: "llake it a Bible-conference kind of meeting. Look to God for His will." 
While it is obvious that the constituency session cannot be all things to all delegates, the few comments that referred to the importance of fervent prayer before the business begins give a good balance: "Should have more concentrated prayer session with all delegates taking part before formal opening of business on hand."

\section{Comnendation/Confidence/Sati sfaction}

On the positive side, there were those who expressed comendation, confidence, or satisfaction--seven from Upper Columbia and another five from Idaho.

Samples of their comments indicate satisfaction with the sessions. Froil an under-40 Idahoan came these words of faith: "I have great faith and trust in our leadership worldwide and feel God needs me to support the efforts of all in such positions. I feel the session I attended was fine."

An older lay Idaho delegate said, "'Effective' and 'efficient' characterize the session now." This expression of confidence in the Idaho leadership came from another above-10 lay delegate: "I have now moved from Idaho to northern California but wish to say I am pleased with the leadership of the Idaho Conference."

Another response indicates that some appreciate the move toward more lay involvement in the Upper Columbia Conference. It was stated by an above-40 1ay delegate: "I'm aware of the effort being made to broaden the input and responsibility of lay members and I heartily approve." 
Another over-f0 layperson: "I appreciate the good job our conference is doing and by and large am very pleased with their coordination of matters."

Finally, this encouraging statement by a younger lay delegate expresses the confidence in God's leadership:

We do believe with all our hearts that this church is Cod-ordained and is meant to be a blessing to the whole world. We are very humbled and happy to be a part of it. Thank you for you efforts and concern in sending out this evaluation.

While it is always encouraging to hear words of commendation, there were certainly sufficient concerns expressed by many of the delegates to varrant some serious evaluation of the current procedures. Out of these findings a strategy was established for addressing these issues in the future. 


\section{STRATEGY FOR ADDRESSING FINDINGS OF THE 1990 UPPER \\ COLUIIBIA AND IDAHO CONFERENCE CONSTITUENCY \\ SESSIONS AS CARRIED OIJT III THE \\ UPPER COLUIIBIA COHFERENCE \\ WITH EVALUATION}

Shortly after the July 1982 mailing of the initial surveys to the Upper Columbia and Idaho conferences, I accepted a call to becone the executive secretary of the IJper Columhia Conference. The specific use of the findings of the 1980 Upper Columbia and Idaho Conference constituency sessions in planning and conducting the next Upper Columbia Conference constituency session are therefore based on what transpired exclusively in the Jpper Columbia Conference.

\section{Preparation for the Session}

Approximately nine months before the 1983 Upper Columbia Conference triennial session which was to be held on April 24, 1983, the administration met with a group of lay members to begin in earnest the groundwork for the session.

With the results of the 1930 survey in hand, it was not difficult to convince the lay cuillilittee members that changes needed to be made. Furthermore, the sirveys held the key to the types of changes that would be most needed and appreciated. While some of the changes were obvious, others were more subtle and would need to be extrapolated from general suggestions. 
Txo changes were evident: considerably more lay input must be obtained anil more work must be completed in advance. To facilitate this, a strategy was outlined and implemented. The lay members of the committee selected what they considered the seven key issues that the church in the Upper Columbia Conference would face during the next triennium. These were as follows:

1. Educational finance

2. Upper Columbia Academy development

3. Total and well-roundet evangelism

4. Nurture and assimilation

5. Financial concerns and directions

6. Strengthening the role of the laity

7. Improving the SDA inage

Next, competent and credible lay members were selected and contacted to chair conmissions in these seven areas. The conference officers and department directors were to serve as resource personnel. These commissions were scheduled to meet at various locations around the conference prior to the constituency meeting so as to facilitato additional suggestions from the constituency.

Constituents were alerted to the plan and their input was sought via printed bulletin inserts (appendixes $A-1, A-2$ ). On one side of the insert was presented a rationale for the comissions; the other side listed the seven commissions and the chaimen with addresses and phone numbers to facil:iate contacts.

These comissions were taken seriously as the members prepared their materials and recommendations to be brought to the Lay Advisory Council, the Conference Executive Colmittee, and, in turn, the constituency session. One chaiman reported that his 
study comission alone had spent in excess of 300 hours going over contributed material.

When the reports had been synthesized and standardized, they were mailed to the local churches for discussion before the session. llore is said about the importance given to these comnissions in the section dealing with the constituency session daily program.

Establishing these commissions served several purposes: (1) it provided the conference administration the advantage of tapping a wide base of expertise among the laity; (2) it allowed the conference personnel to hear what the laity were thinking and what their priorities were; (3) it helped provide direction as to the plans and objectives that should be set for the next triennium; and (4) presumably it helped to jive the laity a realization that they were, in fact, a vital part of the church and therefore were being listened to.

A second area of concern addressed was the amount of information to be disseminated to the delegates prior to and during the session so that they could make informed decisions.

Four weeks before the session a 65-page constituency book was inailed to each delejate. This included not only the traditional departmental and financial reports but also gave a time-sequenced agenda for the day. A letter explaining the purpose and objective of the session was $3 i$ is mailed so delegates could be certain what was expected of ther (see appendix G).

Over and above the constituency report book the volume of prepared documents, work sheets, etc., if laid end to end would have spanned over one mile. 
Constituency Session Progran

The program schedule for the April 24, 1983, session (appendix B) had been sent out prior to the meeting. While many of the activities that transpired during this session were routine, a few of the changes are noteworthy.

Following the reading of the roll call, a felv minutes were taken to share some of the comments that the delegates had submitted on the survey from the previous session. These were carefully selected in advance to reflect some of the concerns expressed by the delegates themselves. This activity helped to set some positive ground rules for the day's activities. While similar comments could have been given by any one of the leaders, the fact that they had come from the constituents themselves added authenticity. A few of the comments derived from the earlier survey and read to the delegates during the preliminaries of this constituency session are offered by way of review.

"Work yroups, mostly lay personnel, should be established long before the session." (This had been done with the seven lay study commissions meeting beforehand around the conference and the Constitution and Bylaws Comittee having a preliminary meeting.)

Several had commented that the smaller delegations should have more voice:

Give more voice to the small churches--most cormittee members are from the largest churches in the biggest cities.

It seemed a few individud"s monopolized more time than necessary on trivial matters--ridatively speaking, persons from the 1 arge constituency groups.

Some comments had revealed obvious frustration for one reason or another: 
The treasurer's repurt was long and boring.

The treasurer's report droned on endlessly.

Let's have room for open business in which small groups could pray and ask the Spirit for creative ideas.

Several had expressed additional frustration on other points:

What has been very distressing to me is all the points of order problems. This consumes a tremendous amount of time and also the hassling through the rewording of changes in the constitution or other. . matters.

I feel that there was too much argument last time about parliamentary procedure. It seemed to me that there were those that were more interested in the parliamentary law than doing the Lord's work.

Too inuch bickering over minor rules.

Additional comments from the same surveys served to highlight the frustration experienced by those who must plan such a session to meet the diverse expectations of those attending. These comments, samples of which follow, were included to make the delegates aware of their varied expectations:

Every session it seems that someone seens to feel that we need to be entertained; so we have a picture show . . . I would suggest that you take that time to take care of the business that needs to be done.

A special talk by an outstanding speaker so all could receive a blessing.

llake it a Bible conference.

He received some good counsel from those who were concerned over the growing tendency towi:d politics: doctors.

llore laymen on commiltees. . not so many ministers and

Hove out of the rut of tradition clear away from political play. Seek the power and guidance of the Holy Spirit. 
And, finally, these valid concerns from the previous

constituency session were shared:

It seems to me that some. . like to hear thenselves talk and waste time on irrelevant minor details that have no real value whatsoever.

I would commend a chaiman that could diplomatically cut of $f$ irrelevant arguing and needless clutter.

There are always some present with discordant ideas they wish to push. I wish they could be cut off quicker, but I really don't have any suggestions for hots.

It had became increasingly clear that the amount of material that had been prepared by the seven lay study commissions was indeed voluminous. With the already packed schedule of business to be transacted, an alternative strategy was needed.

It was therefore decided that rather than prepare the usual not lunches for the session, especially delectable, attractive box lunches vould be provided. At lunch time the delegates were directed to go to one of seven sub-groups of their interest and expertise to be chaired by the commission chairman. During lunch each chaiman then gave a detailed report to those who were interested and in turn received additional input from them.

At a later point on the agenda these chaimen gave refined and condensed reports, along with recomnendations they may have developed, to the entire delegation. This process allowed every delegate the benefit of hearing from all of the groups without finding himself hogged down in areas in which he was not interested or knowledgeable.

One final logistical strategy that is not traditionally employed was the arrangement of the public address system. Due to 
the inadequacy of the existing auditorium system, a special system was rented in an endeavor to achieve excellent sound. ilo roving mikes were used, as is often the case. Two floor mikes were strategically placed between the elevated podium and the first row of chairs.

The dynamic of this was to encourage a person's thoughtful consideration before making a speech. The rationale was that it is much easier to say something less thoughtful if one can quickly grab a roving mike and respond on impulse, without premeditation. Conversely, when a person must leave his seat, walk in front of the entire delegation, and state his name before speaking--sometimes waiting for three or four others to speak before him--there is a higher likelihood of quality speakers. And those who do speak are more articulate.

\section{Evaluation}

As mentioned previously, I had noved to the Upper Columbia Conference during the constituency evaluation project and therefore had access to the delegate iists. Having invested so much personal time and effort, I became curious to see if there would be any appreciable difference in the responses due to the changes addressed in the beginning of this chapter. I sent the same questionnaires as used in 1980 to all 640 eligible delegates to the 1983 Upper Columbia Conference constitumey session with an explanatory cover letter and self-address:d stamped envelope for return. The response from the one and oniy mailing can been seen in the data that follow. 
of the 513 delegates attending the 1933 session, 256 returned usable questionnaires. It was decided lagain in cooperation with my major professor and the Andrews University Institute of Chunch lyinistryl that this data should be included in the project. A brief analysis of these findings as compared with the 1980 Upper Columbia Conference constituency session statistics follows.

\section{Comparison of Pesponses}

Probably the most impressive improvenent was evidenced by the response to question 1: "What was your level of satisfaction witli the last conference constituency session?" While in 1980 only 3.5 percent of the Ipper Columbia Conference delegates were completily satisfied, those satisfied in 1983 jumped to 12.5 percont. Those respondents indicating they were very satisfied went from 34 percent in 1980 to 57.8 percent in $1983--a$ combined total of 70.3 percent in the two top categories in 1983 as compared to 37.5 percent in 1980 (figure 1 ).

This demonstrates that a significant improvement can be realized when the expectations of constituents are addressed. For additional documentation on why delegates responded more positively to question 1 , see figure ?.

Equally important as the resionses to question 1 were the responses to question 3 which addressed credibility: "To what extent did you feel the session was structured to be honest and open?"

Whereas in 1930 only 25.9 percent felt the session was honest and open "A 10t", 36.7 percent expressed that position following the 1983 session. And in 198033.0 percent responded 
What was your level of satisfaction with the last constituency session?

$$
\begin{aligned}
& \text { Not Somewhat Very Completely No } \\
& \text { Satisfied Satisfied Satisfied Satisfied Response }
\end{aligned}
$$

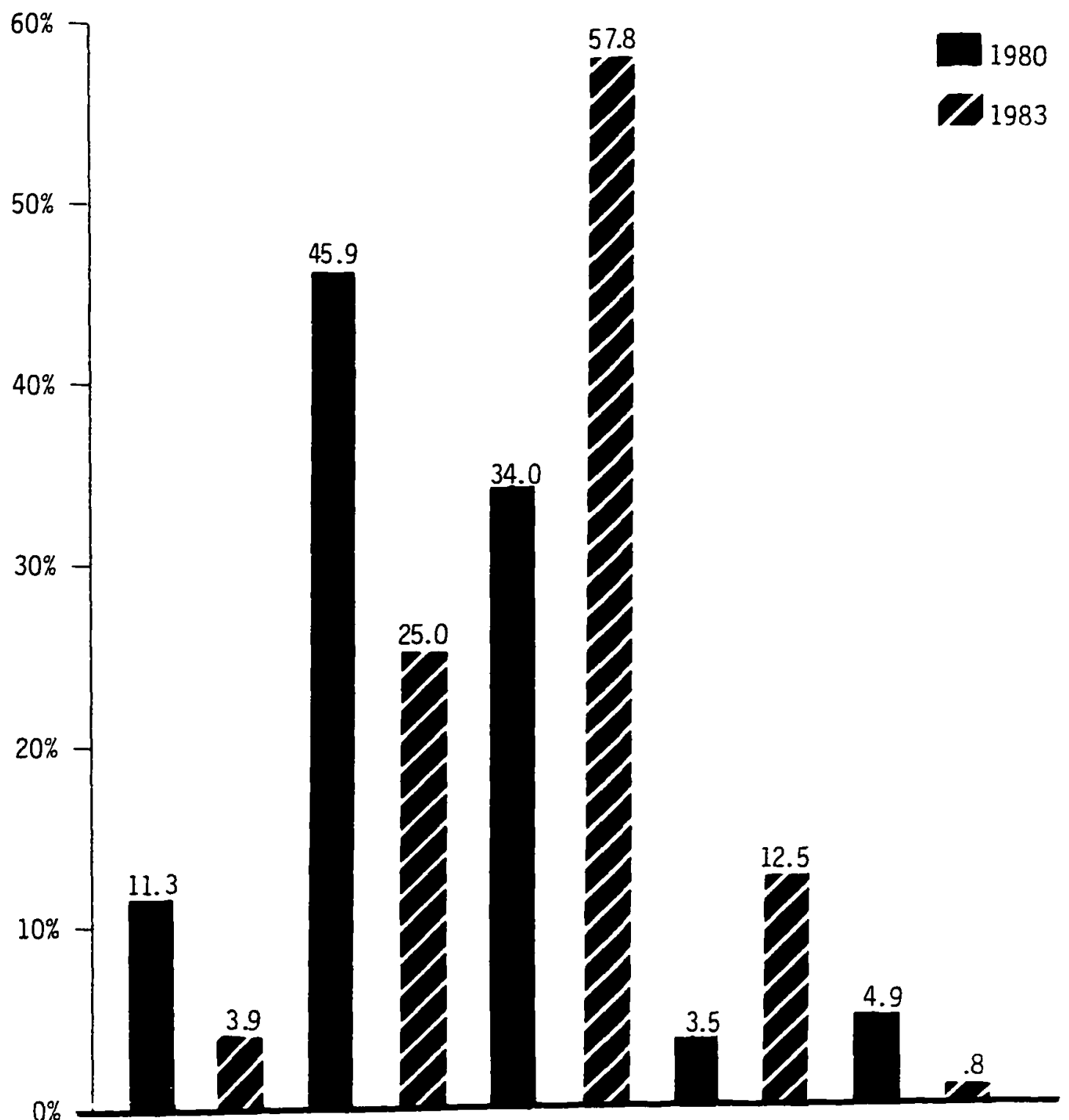

Fig. 1. Response totals by percentage to Question 1 by all groups, 1980 Session and 1983 Session 
Were the following items reasons why you responded as you did to question \#1?

Amount of Dele- Physical Arrange- Schedule of Other gate Participa- ment (seating, Events tion PA, etc.)

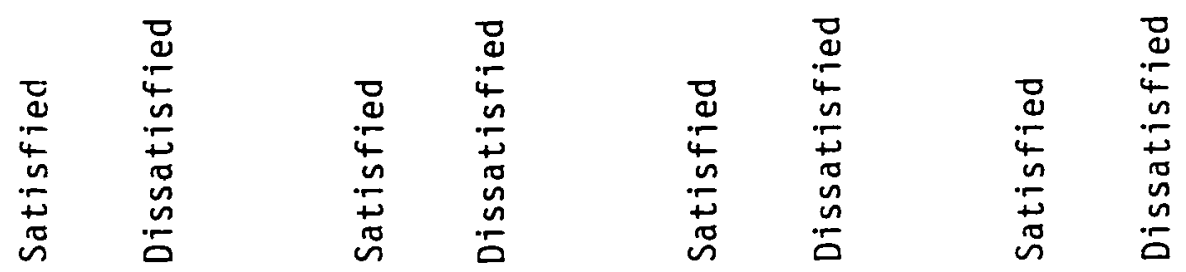

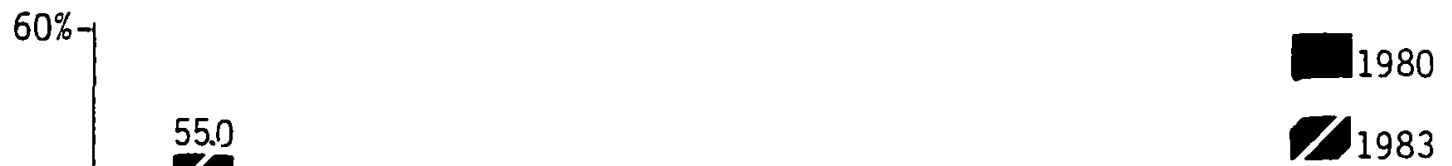


61

"Quite a bit" as opposed to 43.4 percent in 1933. This gave a combined total of the two top categories of 58.9 percent in 1380 in contrast to the noticeably improved 35.1 percent in 1933 (figure 3).

At a time when the credibility of denominational leaders was being seriously questioned due to some unfortunate financial investments of the church, this was a truly hopeful trend.

With emphasis on $13 y$ input prior to and during the 1083 session, as outlined in chapter 4 , it was encouraging to note that many of the delegates comnented on the change.

Question 4 asks, "To what extent did you feel the structure of tile session allowed for your meaningful input in areas of plans, programs, and objectives for the next triennium." In 1980 only 8.1 percent responded "A lot" while in 1283 this percentage jumped to more than double with a 20.7 percent response. The second most positive category, "Quite a bit," went from 20.5 percent in 1330 to 37.5 percent in 1933. This gives a combined two-category total of 28. 6 percent in 1930 as opposed to a much improved 53.2 percent in 1983 (figure 4).

In view of the responses to the preceding four questions, it is not surprising that the ever important confidence level was also raised considerably.

Question 5 adtresses that issue: " $\wedge$ s a result of that session, your confidence in church leadership (1) grew

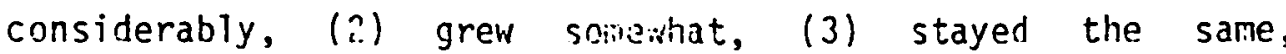
diminished somewhat, (5) diminished considerably."

In 19807.0 percent responded by stating their confidence grew considerabiy while in 1983 the total tripled by jumping to 
To what extent did you feel the session was structured to be honest and open?
Not at
A Little
Somewhat
Quite a
A Lot
No All
Bit
Response

$60 \%$

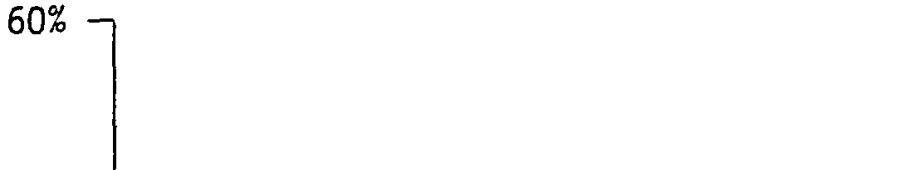

1980

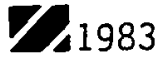

$50 \%$

50

$40 \%$

$-$
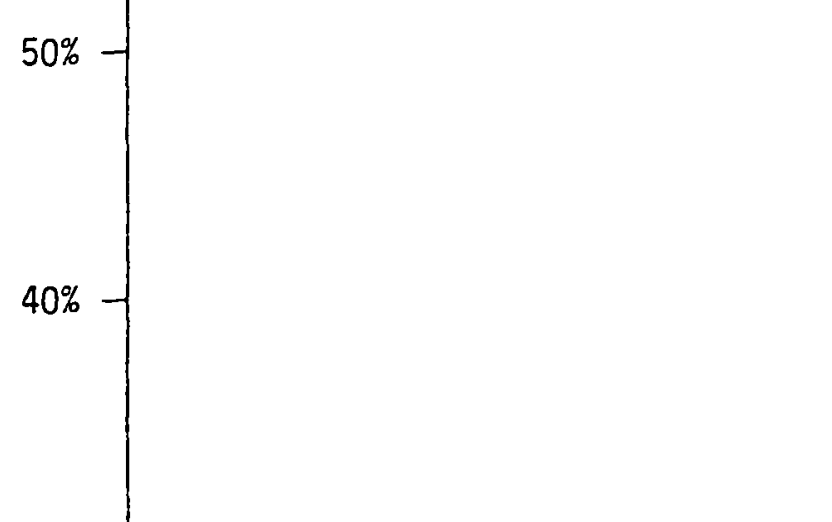

$30 \%$

.

$20 \%$

$20 \%$

$10 \%-$

$0 \%$

2.2

Fig. 3. Response totals by percentage to Question 3 by all groups, 1980 Session and 1983 Session 
To what extent did you feel the structure of the session allowed for your meaningful input in areas of plans, programs and objectives for the next triennium?
Not at
A Littl
Soinewhat
Quite a
A Lot
No
A11
Bit
Response
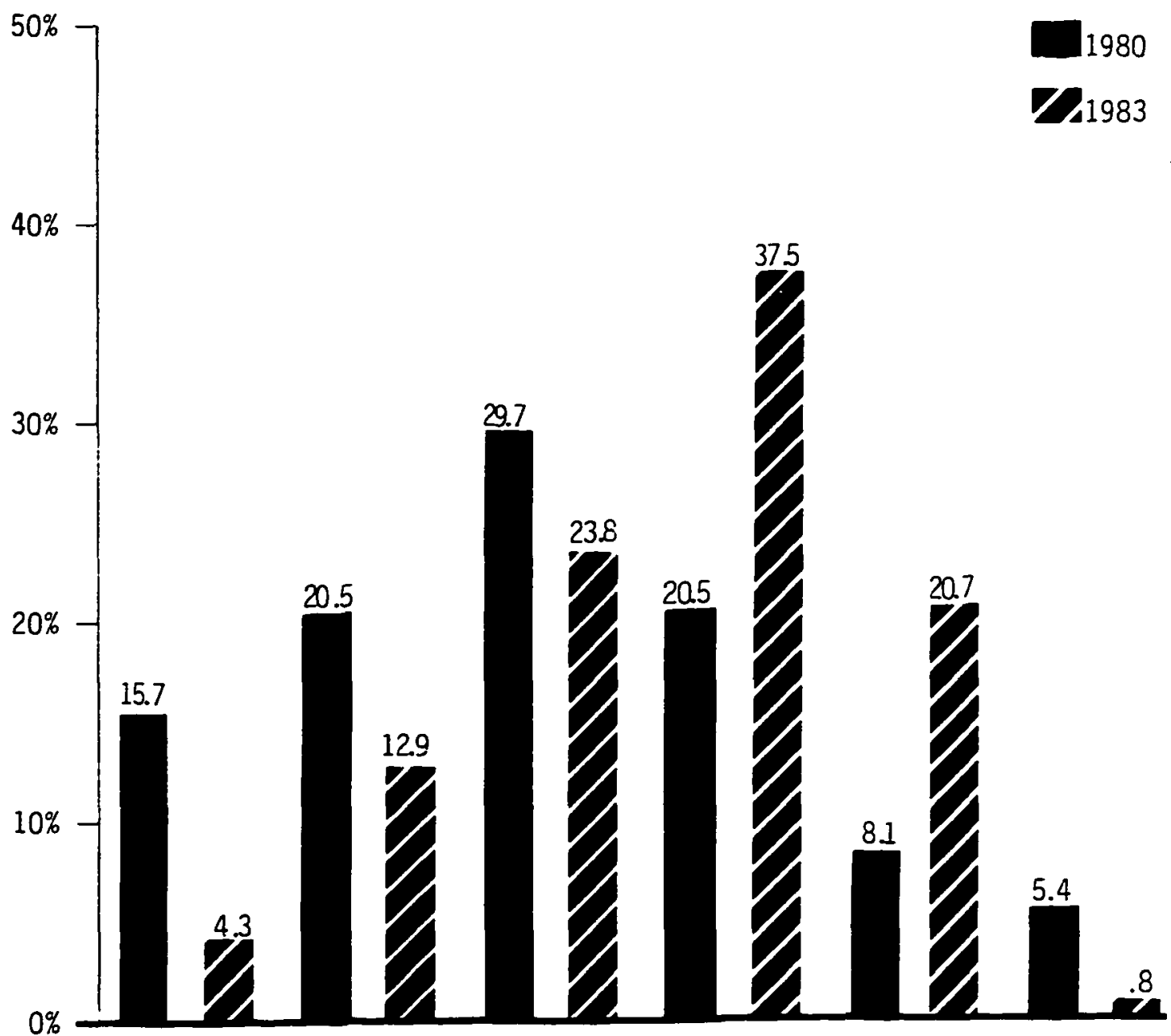

Fig. 4. Response totals by percentage to Question 4 by all groups, 1980 Session and 1983 Session 
21.5 peicent. The second, "Grew somewhat," ient from 15.7 percent in 1900 to 80.5 percent in i303. This reversai bile negatios improvement shown in 1980 in the category "Diminishet somewhat" of 10.8 percent down to 5.1 percent and "Diminished considerably" 3.8 percent in 1200 to nnly .8 percent in 1933 (figure 5). These are trends that any conference administrator would be exceptionally pleased to see.

\section{Understanding of Pruceedings}

On the surface, the response to question 7 , "How much of the proceedings did you understand?"is rather surprising. It is tire one question that shows a reversal when compared to the preceding constituency session. In 198054.6 percent of the respondents indicated they understood nost of the proceedings as opposed to only 27.7 percent in 1983. And 29.2 percent in 1980 said they understood all as opposed to only .8 percent in 1933 (figure 6).

However, there seens to be a rather simple explanation. With the emphasis on more involvement by the delegates --specifically the various study comission reports--there was a degree of frustration on the part of some because of the volume of material being presented (in many cases presented hy lay members) in restricted periods of time.

This area needs to be given additional study in an endeavor to improve. The negative findings should not be overly discouraging, however, in view of the extremely positive responses the other questions received. 
As a result of that session, your confidence in church leadership:

$\begin{array}{cccc}\text { Grew } & \text { Grew } & \text { Stayed Diminished Diminished No } \\ \text { Somewhat Considerably Response }\end{array}$

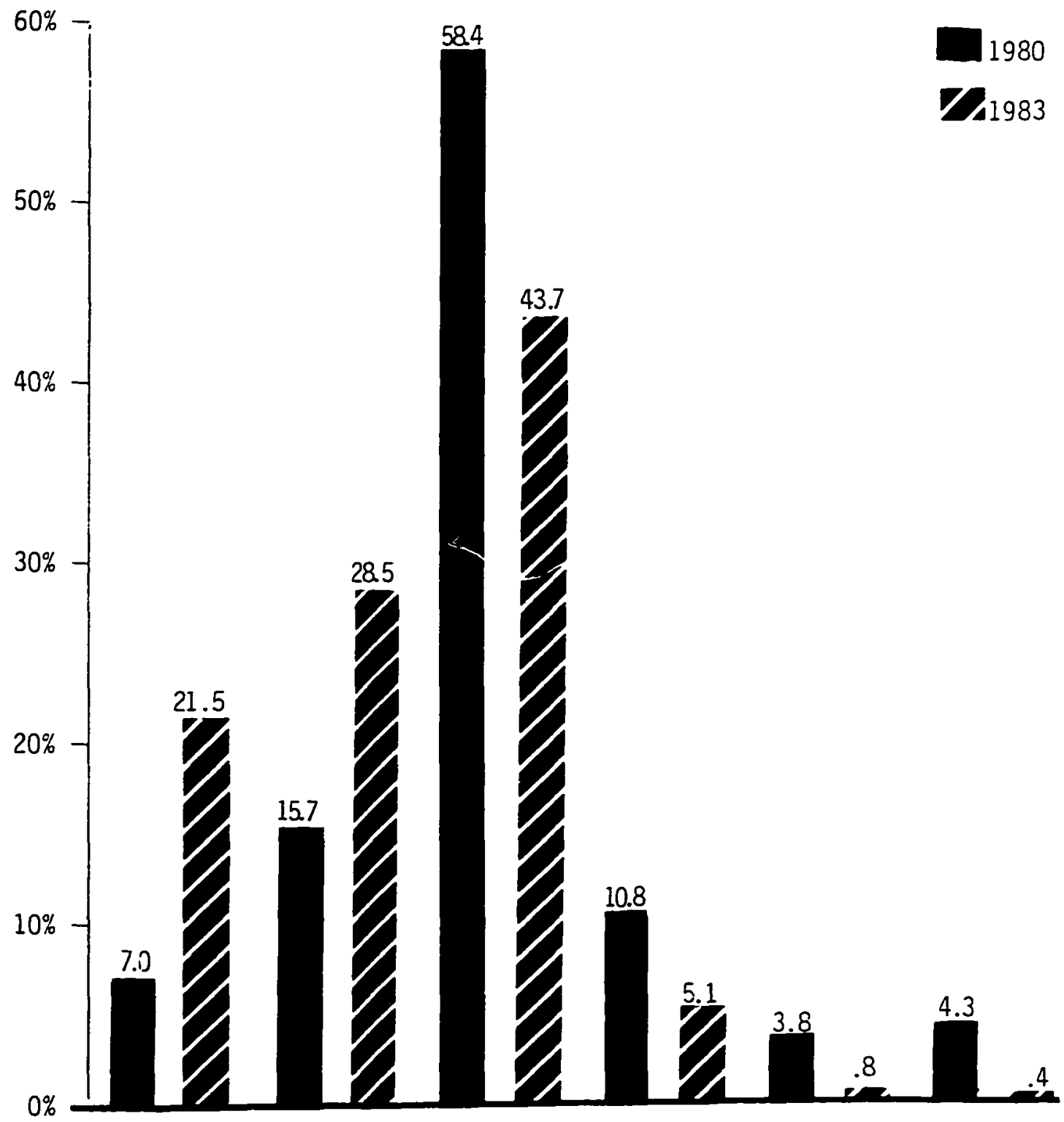

Fig. 5. Response totals by percentage to Question 5 by all groups, 1980 Session and 1983 Session 
How much of the proceedings did you understand?

None Hittle Most All $\begin{gathered}\text { No } \\ \text { Response }\end{gathered}$

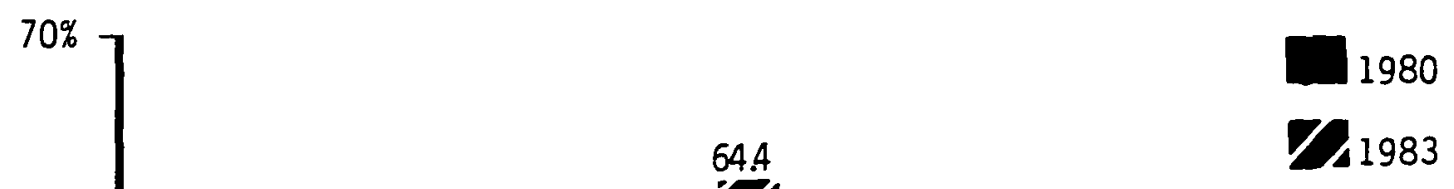

$60 \%$

$40 \%$

$50 \%$

$60 \%$

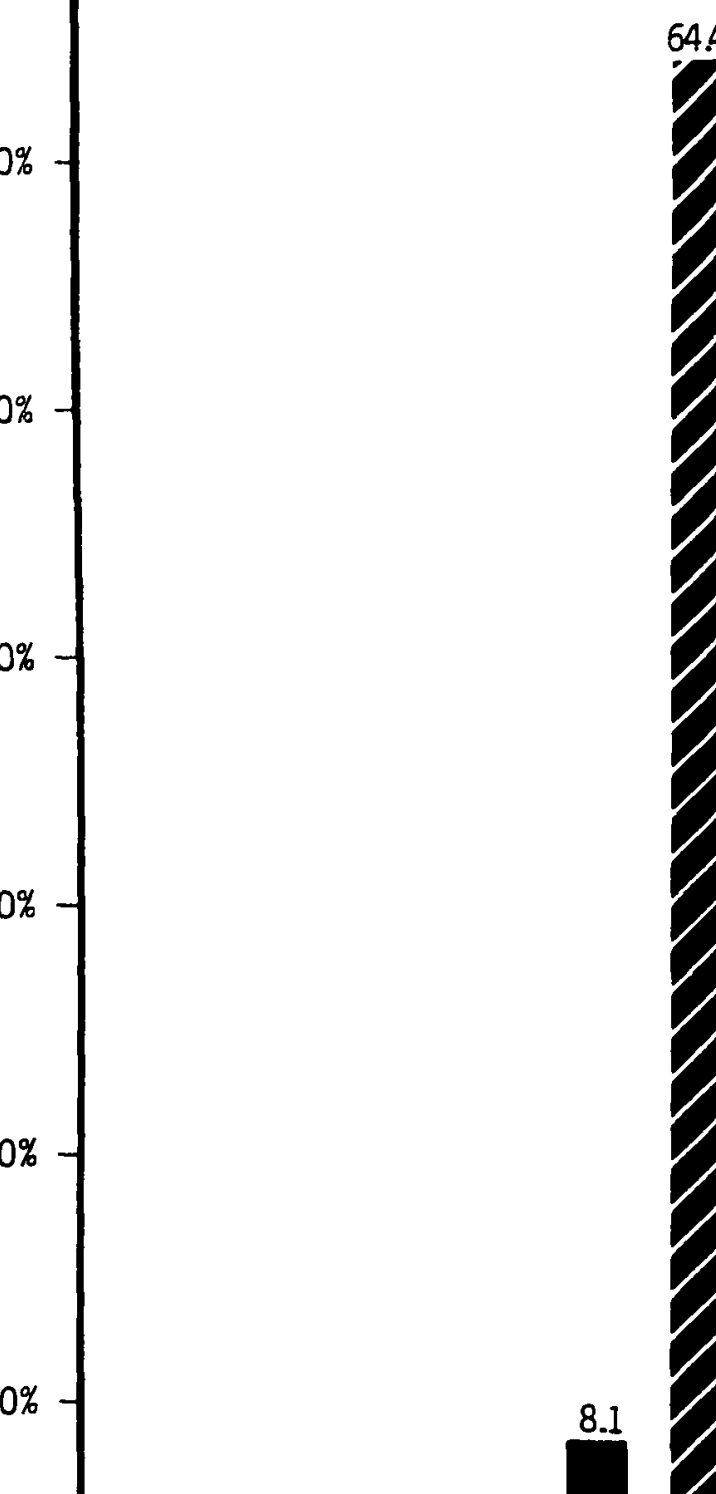

54.6

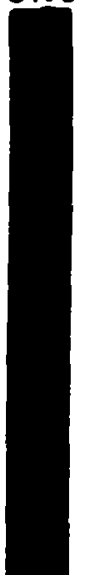

$30 \%$

$20 \%$

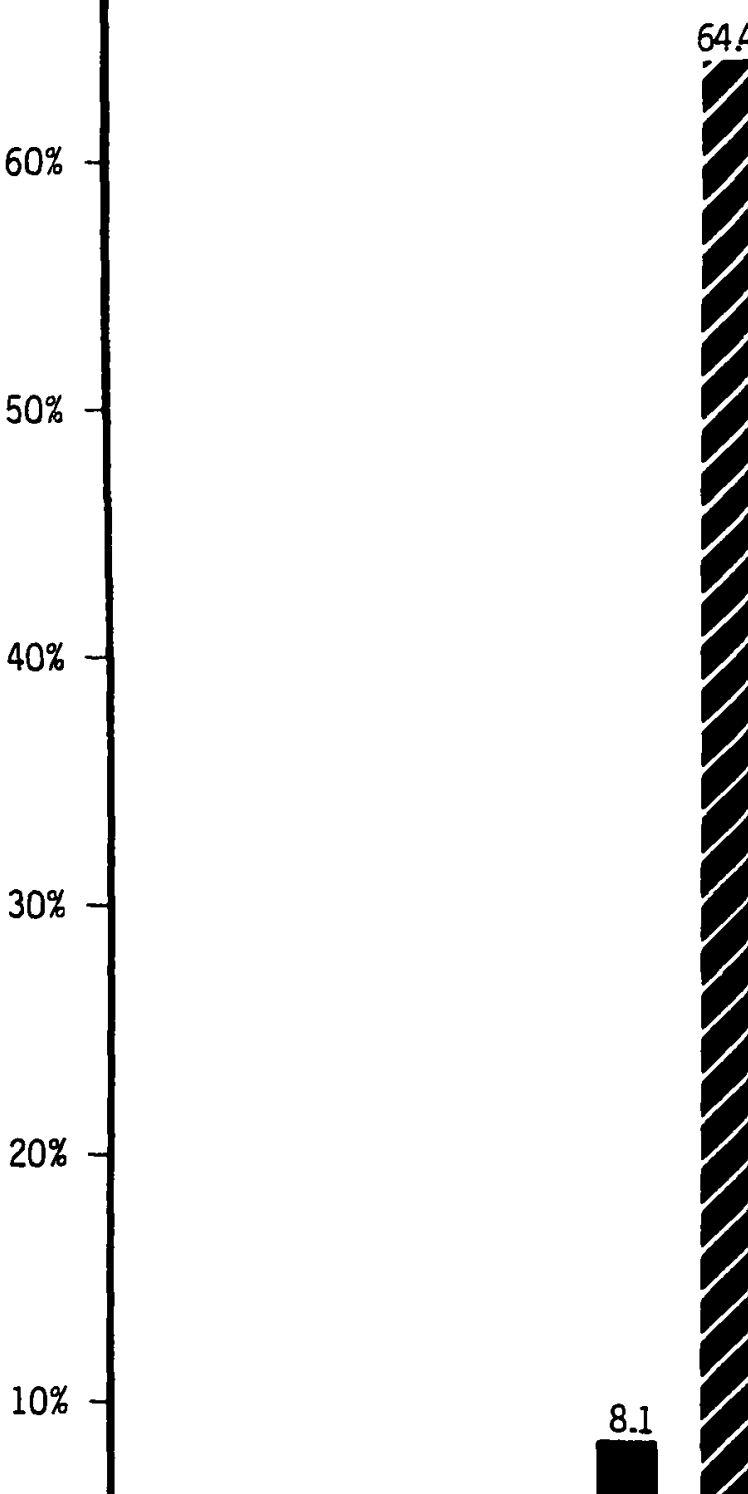

8.1

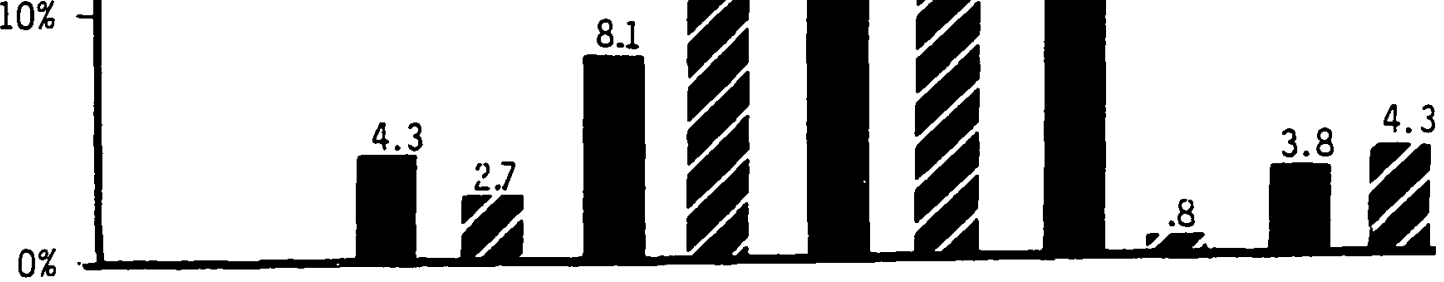

Fig. 6. Response totals by percentage to Question 7 by all groups, 1980 Session and 1983 Session 
A higher percentage of the respondents to the 1983 Upper Columbia survey chose to express their feelings and suggestions through the open-ended opportunity in question 9 than did the respondents in the 1980 Upper Columbia and idaho surveys. Part of the reason for this, no doubt, was the fact that the previous surveys were mailed out two and one-half years after the event whereas the 1983 surveys vere sent two months after the event.

\section{Suggestions for Improvement}

Question 9 read as follows: "What other suggestions would you like to make that would na!se the upcoming constituency sessions more effective and efficient?" Due to 133 written responses, it is again impossible to deal witl every individual suggestion. Again, as in chapter 3 , the comments are grouped under the following eight categories:

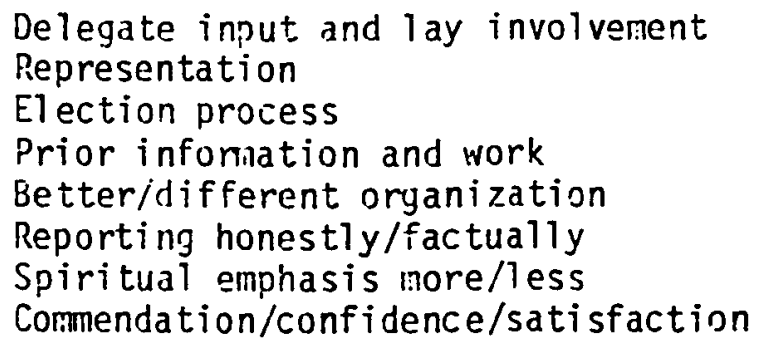

Due to the subjectivity of trying to detemine into which category a suggestion or comment should be placed, the figures cited below are all approximate.

\section{Invil: by Lay ilembers}

Twelve individuais commented on the area of more delegate or lay input. The current definition in the constitution of a layperson as anyone not on Upper Columbia Conference payroll 
prompted this conment by an above-10 layperson: "A layman is a person who is not on a church payroll or a person who will never be on a pension plan. We are not honest as to defining a layman."

A faniliar suggestion was evident in the following comment by another above-10 delegate stating that the cinancial expertise of laymen should be increasingly implemented:

There is a crying need for more lay members with backgrounds that qualify them to be better business men than the ministers who are on the conference board. There are altogether too many ministers who are "waiting on tables" instead of preaching the word and "giving Bible studies."

Finally, another lay member expressed a concern for overreacting to the current move toward lay involvenent this way:

Because of the shock wave our nembers have suffered from our recent problems, I fear a swing too far toward membership input. There needs to be caution here. I understand we all need to be a part of God's work but we all can't be leaders. However, we all need to support our leaders and let them do their job the way the Lord leads them.

\section{Representation}

The second category is closely related but speaks of some additional frustrations beyond those already mentioned. Approximately fifteen comments fall into this area.

One under-40 pastor felt that the committees they had elected had too much responsibility:

I think more time and deciding power should be given to the delegates in the main meetirig. I think the small comittees should outline suggestions, do research, and give reasonings to equip tike large neeting to lirke more and better decisions. This was done to a small degree, but the small committees had too much deciding power and should have brought more of the decisions back to the floor.

There are always those people who feel that some individuals tend to dominate the session: "A few people seem to 
always iominate the discussion because they feel strongly ahout the problem and have the courage to stand up; so the decision seems to go their way."

Several comnentators yithin this category said that there should be fewer delegates so the participation ratio could be higher. "Redure the number of delegates" expresses the feelings of one over-40 delegate. And a sentiment expressed by two delegates was for nore input by the smaller churches: "It seems if you are from a small church you get very little input and are not represented un any of the comnittees, etc. This hardly seems right!"

\section{Election}

Primarily the tivelve coments in the election area dealt with the election of the conference personnel and, more specifically, the officers. Several respondents mentioned specifically having a ballot. One below-40 pastor wanted to ballot and do it quickly": "Use ballots for elections as soon as delegates register (computer cards) and get it over quickly." An above-40 pastor was concerned : vith committee selections:

I feel strongly that those who serve on the nominating cormittee should not be elected to the new conference committee. This session was a disgrace in this regard.' Names of regular lay leaders could be submitted by pastors in advance for consideration to serve on conference committee.

\section{Prior Infermation and l!ork}

Approximately twenty-inree delegates spoke to the issue of either receiving more information preceding the session or of convening the committees sooner.

Another fifteen corments concerned the need for the committees. Obvious frustration was expressed by the fact that 
inherently too nuch must be done at this session. One above-40 lay delegate member points to the fact that the nominating committee, per constitution change, became a standing committee so that should an officer leave office during the term, the nominating committee would be called back into session with the Conference Executive Committee for the election of a replacement:

The noninating comrnittee cannot do its job effectively in the time frame it is given to operate in. Changing the status of this comrittee to a standing comittee is a gnod start, hut I feel continued study should be given to improving the operating performance of all committees.

The nominating committee and its function is possibly the area generating the most dissatisfaction, not oniy with the delegates but also with conference personnel. A discussion with two men who have served as conference presidents for a combined total of more than twenty-five years revealed that they likewise were frustrated.

One of them stated: "The nominating committee has absolute authority one day and absolutely no authority the next." He went on to indicate that with the vesting of the authority went the loss of responsibility for the actions taken. Another man expressef similar concerns in that the policies and fecisions of his administration were judged without the presence of one person from the Conference Executiv? Compittee that took the action and, therefore, supposedly understood the rationale for it.

While the Ipper Columbia Conference took a step in the right direction by making the nominating committee a standing committee, possibly the second step of having Conference Executive Committee representation on the nominating committee would be even 
a more complete step. The final :rord has not been said on this topic, and additional study should be given to a fair amount of input being given to the delegates without moving into the political area of multiple names on the ballot.

Regarding the constitution and bylaws connittee which also was voted as a standing committee, this goud comment was made:

I helieve it is not necessary to read in detail all the bylaws and amendinents which seem to take up so much time and which very few understand or are interested in. The leaders could send them out to delegates with the reports ahead of time and let them examine and take notes. Then if there are any questions bring them up before a committee who does understand the legal aspects and discuss them; tinis would save much time for other matters that are on the delegates' minds.

A baldnce must be kept in wind, ton, so that when the pre-irork is done there is still a chance for input and change. This idea is expressed by this under-40 lay delegate:

I felt frustrated because it seemed to me that the study commission I visited had already reached its conclusions and made its recomnendations; and while the members seemed interested enough in listening to discussion, it was too ?ate to make any changes in the recommendations.

\section{Setter/Different Organization}

While the largest number of comments this time fell into the organization category, many of the suggestions were technical or logistical in nature such as moving the location to a different geographical aited, chanye :l time of year, and/or better facilities. While ten soments dealt with cutting the preliminaries, in general, àproximately six specifically suggested eliminating entirely or partially the multimedia report. One under-40 laymen expressed the feelings of others: "llore detailed work of what is to be presented--beforehand. The time is so 
1 imited-only about 6-8 hours." Their comnents at first would be surprising to most administrators who can remember the old verbal reports and contrast those with the improvement of the multimedia which is now in vogue. Those, however, who are expressing frustration with too little time for what they consider the real business, see these preliminaries as a time-consuming extra which should be minimized at least.

\section{Reporting Honestly/Factually}

Only seven comments were placed in this category. While most would follow the same line of thinking as would the comments under this category in the 1980 survey, one new, valid suggestion was made by a below-40 layperson: "Report back as to progress on suggestions (proposals) of prior session made by comrittees (1ay study, finance, planning, etc)."

\section{Spiritual Emphasis liore/Less}

Thirteen comments ivere grouped under the spiritual heading. Following the concerns expressed earlier about insufficient tine for the business of the day, eight persons suggested that less tine or none at ail be given to devotional presentations. A rather insightful statenent was made by one over-40 lay member: "An izilive church nember should not need spiritual growth programs it a constituency meeting." This was echoed by another over-90 delegate:

Since the session is so long--and necessarily so--I would have prefered to get right into it and not hear the academy chorus, etc. We get spiritual feeding at church; I would rather have had a good prayer session for guidance and get on with it (the business part). 
Tinree people suggestef that a spiritual weekend could be planned beginning Friday afternoon and then the business could begin early junday morning. A logistical problem not taken into account by these latter suggestions would be the housing of delejates.

\section{Commendations/Confidence/Satisfaction}

Finally, approximately twenty-three people expressed their appreciation for a part or all of the session and/or their ongoing confidence. A comment from an above-40 layperson follows:

I thought things were handled woll and I have a deep sadness that some people have such a suspicious attitude. They seem to always feel that our administrators are trying to pull a fast one. I dislike that attitude. I feel we are all working together to hasten our Lord's return and we should be positive in our attitudes and conduct.

While the sessions are not perfect in this above-10 layperson's viewpoint, things are moving in the right direction: "You did a great job improvin'g from what I attended before." And this upbeat response comes from another above-40 delegate: "This year is the best yet; keep the trend onen."

Finally, some comments by an above-40 laymen and an above-40 pastor expressing what every administrator wishes every constituent felt. The layman stated: "I would like to personally thank our leaders who confuried an honest, open, and efficient meeting"; while the pastsp somiented:

Considering the business to be done and the time elenent, other than ahove suggestions, I don't know. It is a wearing time schedule. I was deeply gratified with the spiritual atmosphere and the serving attitude of our leadership. You were not 'defensive,' but tried to be helpful throughout the meeting. The lunch was superb and I hope will become a future part of the meeting. It was the best I have ever seen planned 
and prepared. It was a relaxing and morale-building neal. Frankly, I was proud and happy over the whole meeting.

proid and happy over the whole meeting.

It was encouraging to again hear the positive comnents of appreciation. Equally important, however, was the improvement, sometimes dramatic, in the general attitude of the delegates toward the constituency session. While there are still definite areas that need improvement, the trend is in the right direction.

\section{Summary}

So it can be seen that the satisfaction level and the confidence level of constituents can definitely be raised. There continues to be a call for more lay involvement by many of the constituents. This is despite the fact that more lay people were involved in the planning and carrying out of the second session. There may be some trade-off shown here as the level of understanding dropped off with the complexity of the increased numbers of individuals involved. 


\title{
CHAPTER $V$
}

\section{THEOLOGICAL AND THEORETICAL BRIEF \\ WITH CONCLUSIONS}

\begin{abstract}
A thoughtful businessman remarked that he had discovered a new reason for believing that the church is a divine institution. "No other enterprise," said he, "could survive if managed so haphazardly." Others echo the cry with, "If I ran illy company like you run the church, I'd be out of business."
\end{abstract}

The administrators whon I know are competent and progressive, eager to improve leadership skills. Conference presidents are open to suggestions for the improvement of constituency meetings such as this study undertook. Any suggestions or recommendations which might emerge out of this project, it would seem, should be placed within a theological and theoretical context.

In this chapter I wish to reflect upon possible implications of this research paper for the church and its ministerial learlers. Observations based upon Biblical and theoretical considerations are offered.

\section{Biblical Principles}

Theologians in general have not concerned themselves with concepts such as planning strategies and evaluation, however. At 
the very outset the Bible presents what Christian "managers" have identified as the three foundational principles of management or stewardship--principles which when followed lead to success, principles which when neglected lead to less than an efficient organization at best and wholesale failure at worst. They are found in Gen $2: 15-17$.

Principle 1: llave clearly defined and understood objectives. In Adam's case it was to dress and keep the garden.

Principle 2: Solicit cooperation through delegation. God did not plan to take care of the garden; He delegated the responsibility to Adam and Eve.

Principle 3: Define terins of accountability. Adam and Fve were specifically told not to eat of the Tree of Knowledge of Good and Evil, and if they did they would surely die.

These three Christian management principles are as old as creation--as new as the latest management theory book. Fron them stem such basics as planning, shared leadership, and evaluation. Yet God's leaders have had difficulty endeavoring to operate with these principles and have run into problems when they have forgotten one or more of them. Biblical examples help to reinforce these premises.

One of the greatest achievements in building, up to its time (and probably to uur time), was the construction of lloah's ark. In a sense, the traditional nomenclature of "Noah's" ark is incorrect. In Gen 6, it is clearly stated that God told Noah that a giant ship should be built. Not only did God give Noah the objective of building an ark, He very clearly outlined the specifics. 
God gave Noah the exact dimensions of the ark and explicit directions in regard to its construction in every particular. Human wisdom could not have devised a structure of so great strength and dyrability. God was the designer, and Hoah the master builder.

For the next 120 years with the assistance of his three sons to whom he delegated part of the responsibility, Noah labored to build the ark according to the detailed directions. When the flood finally came and all the inhabitants of the earth were destroyed in an act of divine judgment laccountability, evaluation), Hoah and his family must have been grateful for clearly defined and understood planning and objectives.

These principles are also demonstrated in the life and work of lloses. He are pleased when we successfully plan and orchestrate a church convention (campmeeting) for a few thousand people for ten days. Hoses had 600,000 men plus yomen and children besides a large number of the "mixed multitude." In addition, there were no sanitation facilities or food service department: As one has noted:

To maintain order and discipline among the vast, ignorant, and untrained multitude was indeed a stupendous task.? lloses had to be reminded in Exod 10:18: "Thou wilt surely wear away. . . This thing is too heavy for thee. Thou art not able to perform it thy self alone."

Moses was exhausted--possibiy a bit irritable, too--and while Jethro usually gets the credit for his counsel, one writer

IEllen G. White, Patriarchs and Prophets (Hountain View, CA: Pacific Press Pub. Assn., 1953), p. 92.

2 Ibid., p. 300. 
suggests that it was actually 'loses' wife, zipporah, who reported the situation to Jethro originally.'

Confronting lloses, Jethro implied that one of God's management principles had been neglected. lloses had not solicited cooperation through delegation. Jethro, therefore, counseled him to delegate the responsibility of leadership--to solicit the involvement of the laity and appoint proper persons as rulers of thousands and others as rulers of hundreds and of tens. Leaders today, like iloses of old, must be reminded that they must share responsibility.

The importance of planning and strategy are pointed out in God's dealings with ancient Israel. When God was ready to lead His people out of Egypt to the Promised Land, He provided a special place for worship. First, He made provision for the resources necessary in their worship plan. "Speak unto the children of Israel, that they may bring me an offering: of every man that giveth it willingly with his heart ye shall take my offering." Then He added: "And let them build me a sanctuary that I may dwell among them. According to all that I shew thee, after the pattern of the tabernacle, and the pattern of all the instruments thereof, even so shall ye make it." (Exor 25:2, 8, ?)

God also prescribed a pian for the priesthood, the priest's clothing, and the services of the sanctuary. In His plan God pointed to the hoped-for outcome of all these activities, "that they may serve me." (Exod $0: 1$ )

1 Ibid., p. 384. 
Clearly, the Bible provides rich resources for organizational thought. iloses' model of delegation, as noted, provides a basis for all division of lahor and job-structuring. The selection of deacons in the early church was in response to a need for the central officers to function according to their priorities, rather than secondary assignments. When planning for the Last Supper, Jesus made personal assignments of responsibilities, expecting those assignments to be carried out. When one part of the preparation, the footwashing, was overlooked by a servant, He used the occasion to introduce the concept of servant-1eadership. Jesus was a master in the techniques of member involvement. ile continually confronted those who came into His Presence, calling for response, action, change, comititment.

\section{Sorie Reflections}

As I reflect upon the results of this study, several impressions emerge upon which I wish to conment.

It is clear that conference administrators must find ways to broaden the base of involvement, participation, and tecision making on the part of delegates to these constituency sessions. Our day is characterized by a rising demand for "power" for the individual in his institutional life. People are expressing themselves more forcefully on what they want. There is a distaste for hierarchical structures and authoritarian leaders. llembers are looking for leaders "who are able to enlist them in a spirit of partnership around projects that have immediate consequences while serving a higher and well-articulated vision." 1

J Jack K. Fordyce and Raymond Heil, Managing with People (Reading, MA: Addison-Wesley Publishing Co., 1971), p. 7. 
Dennis, looking to the future, suggests that "the increased level of education and mobility will change the values we hold about work. People will be more intellectually committed to their jobs and will probably require more involvement, participation, and autonomy." 1 The words involvement, participation, and autonomy are to be emphasized for they are the pillars of management by objectives, an approach to administration emphasized in the church today. In their healthy manifestation, these aspirations are in keeping with the creation of man in the image of God as a free being. God delights in freedom. He has willed that man possess a will and that that will shall be free. Therefore, He despises tyranny. He does not compel but seeks rather to win over. The work and mission of the church are best achiever in such a climate and spirit. Unilateral decision making and unidirectional communication are incompatible with the basic nature of the church. Instead, a new collaborative relationship must emerge in which persons with their variety of gifts may mutualiy decide how, when, and which gifts will be used in the work and service of the church. Church organizations in which management hy objectives is taken seriously will be open to new ideas, freer to meet a variety of challenges, and more able to perceive the value of the contributions of all members.

Another observation pertains to the positive acceptance of a plan for evaluation which is aimed at improving process as represented by this project. Dur day is characterized also by a

1 Harren G. Dennis, Changing Organizations (New York: HcGrai-Hi11, Co., 1966), p. 11. 
passion for truth and candor. Kung, who writes of truthfulness as a basic requirement of the church, believes that "the future belongs. - to a church which is strong in faith, joyous and certain, yet self critical."l

This truthfulness to itself may take place as it is public in its planning, decision making, and self-evaluation. Public processes help to surface information regarding values and expectations of the people. Evaluation processes provide information regarding the perceptions of people with respect to the achievement of objectives, the quality of their life together, and the degree to which the results of their activities match the enunciated vision.

Worley emphasizes public morality and public processes in the church as opposed to private (individual) morality and private processes. $^{2}$ Leadership in the church must devise ways to assist congregations to think about their corporate life, their faith commitments, and the care of their members and their families. Even leadership itself, its style and quality, should be open to examination by persons affected by its actions. This means that both leaders and members are responsible for examining their common life. Processes must be devised by means of which the leader enables a congregation to face itself and to make decisions about what it sees. In this way not only does leadership have an opportunity to be prophetic and prudent in its rule, but the

THans Kung, Truthfulness: The Future of the Church (New York: Sheed \& Hard, T368), p. 49.

2Robert C. Worley, Dry Bones Breathe, (Chicago: Brethren Press, 19781, p. 33ff. 
congregation also is provided opportunity to express its wiston and self-understanding.

In short, leadership must be puhlic in doing good if it is to gain legitimacy from members; private activity must only lead to passivity.

\section{Inplications Pertaining to Church ileetings}

The view seems to prevail that church meetings cannot fail because God is in control. But some do fail--they fail because people fail, not because of an inadequacy on God's part.

Considerable literature exists on how to conduct effective meetings. Many offer information that can inform the religious community. Schindler-Rainman and Lippitt outline the basics of three approacies:

In view of their importance as instruments of human endeavor it is tragic that most meetings are so bad. The main explanation of this being the case, as I see it, is that traditionaliy our meetings have followed one or both of two historical models: the lecturer-audience classroom model dating from the medieval school, and the parliamentary model invented by English barons in the thirteenth century. The purpose of both models was to assure that those in power could maintain their control over those under them. Both models are characterized by rigid control by authority figures, fomal rules, regulations and procedures, and standardized rituais.

Perhaps these models served virtuous purposes at the time they were conceived. The classroom model provided an orderly means of transmitting knowledge before printing presses were invented; and the parliamentary model enabled the barons to restrain the monarchs without relinquishing power to the vulgar inasses. Sut as the concepts, values, and procedures of democracy began evolving in the late eighteenth century, these models began losing their relevance, and in the twentieth century they became totally dysfunctional.

What was needed was a new model to provide guidelines for human interactions that were more congruent with democratic ideals. To meet this criterian a new model would need to possess these characteristics: (1) respect for personality, (2) participation in decision-making, (3) freedom of expression 
and availability of information, and (4) planning and conducting programs and evaluating.

Leland Bradford points up the need for inutual trust between leaders and people for effective meetings:

llaking meetings work requires a leader who is willing to risk being creative, imaginative, and effective, a leader who invites and challenges group members to take the same risk. lleetings work because people learn to trust and cooperate as they work together.

Doyle and Strause discuss the need to be sensitive to meeting processes as well as meeting context:

This distinction between the content (the what: problem, topic, or agenda) and the process (the how: approach, method, or procedurel is a difficult but vitally important concept to grasp if you are going to understand why meetings don't work we11.3

They then suggest five basic criteria for a good meeting:

1. There must be a common focus as content.

2. There must a common focus on process.

3. Someone must be responsible for maintaining an open and balanced conversational flow.

4. Someone must be responsible for protecting individuals from personal attack.

5. And, in general, for the duration of the meeting everyone's role and responsibility must be clearly defined and agreed upon. 4

Schindler-Rainman and Lippett suggest ten areas of characteristics that all meetings have in common: "(1) people,

lEva Schindler-Rainman and Ronald Lippitt, Taking Your lleetings Out of the Doldrums (LaJolla, CA: University Associates, 1979), p. 5.

2Leland P. Bradford, llaking lleetings Work (La Jolla, CA: University Associates, 1976), p. 13.

3Michael Doyle and David Strause, How to llake lleetings Work (New York: Wayden Books, 1976), p. 24.

${ }^{4}$ Ib id., p. 32. 
(2) purpose (3) atmosphere and cilmate, (4) place and (5) cost,

(6) time dimensions, (7) work before meeting, (8) plans, program agenda, (3) beginning, middles, and endings, and (10) followup. 1

Christian meetings must find a balance between the demand for order and for openness and the working of the Holy Spirit. They must grant freedom to choose responsibly from among the alternatives. When they are too openly conducted, they result in confusion; when they are too tightly structured, they may inhibit the communication of God with His people through the Holy Spirit.

Christian meetings should always have a degree of openness, freedom, and flexibility. The ultimate chaiman is not the presiding minister but cod who desires to communicate with itis people, and His actions cannot be prescribed.

Written plans and objectives facilitate an honest pursuit of a course of action, and planning documents help take aivay the uncertainty and possible distrust associated with closed planning sessions. In planning for such sessions, the mission and objectives inust be clearly stated.

\section{Conclusions}

This study has reminded me again of currents of change at work in the world as vell as in the church. For some tine SDA churchmen have been aware of a ciamor for change in our church structure.

It is true there will be various voices calling for different types of change. As a church of over four million

\footnotetext{
${ }^{1}$ Schindler-Rainman and Lippitt, pp. 17-13.
} 
members this is only logical. It happened when we were a fraction of the size we are today. But different ideas, different opinions are healthy! And these various points of view should be heard fron every section, including those in academia. God never expected us to be a church of four million clones. The key is that we must accept this healthy interchange in an environment of unity, not unifomity. As in the comments regarding the selection of the conference personnel, the laity are not all convinced of the exact procedural changes tinat should be made but many are saying change is needed. If appropriate response is not made, undesirable consequences could ensue. A specific focal point for change for many members is the conference constituency session. This is logical since the average layperson has little opportunity to vent his feelings of frustration except at the trienniel session. For that reason this one event has an inordinate amount of importance as this church builds on the past for a successful future.

The changes will, and no doubt should, be slow, well thought through, but definitely perceptible. ${ }^{1}$ Drastic changes in church structure, however, are not advocated here. As with many successful American business organizations, what may be indicated is a "rearranging" of "ornaments but seldom the branches."?

J. C. Penney is supposed to have said something to the effect that if you have been doing something for twenty years that

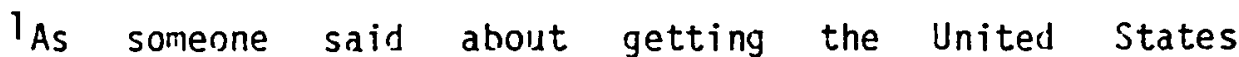
bureaucracy to change, it is like kicking a dinosaur in January and hearing it groan in July.

2Thomas 3. Peters and Robert W. Wateman, Jr., In Jearch of Excellence (New York: Narner Books, 1983), D. 3. 
in itself indicates it needs to be changed. There is some truth to that. But a wholesale change of the structure that has served the church well could be not only traunatic but self-defeating.

Charles E. Bradford, president of the North American Division of the Seventh-day Adventist Church, refers to the current obsession by sone to see drastic changes in church structures:

This seems to be the greatest issue of the moment. Everybody is suddenly an organizational expert. There is a great deal of discussion going forward in every sector and on every level of the church about organization, reorganization, and structure. Armchair consultants are a dime a dozen.

llay I point out that our theology and our organization grew up side by side and developed painstakingly hy trial and error, separating wheat from chaff, what works from what does not work. llore than a century has gone into this growtin development. We are no better than our fathers. We stand on the shoulders of those who have preceded us. He must guard against arrogance. Humility and respect for the past is in order. One of the curses of the modern age is that we have no regard for the past. But a people without a history is like a person without a memory. Therefore, we should nged to moderate and control the urge to tamper with organization.

As Peters and Waterman suggest, perhaps more critical than changing structures is the need to "change our ways:"

At a gut level, all of us know that much more goes into the process of keeping a large organization vital and responsive than policy statements, new strategies, plans, budgets, and organizational charts can possibly depict. But all too often we behave as though we don't know it. If we want change, we fiddle with the strategy. Or we change the structure. Perhaps the time has come to change our ways.?

lcharies E. Bradfori, address given to the Complete Administrator Seminar, Andrews University, Berrien Springs, llichigan, September 1903.

2peters and Haterman, P. 3 


\section{CHAPTER VI}

\section{CONCLUSIONS AND RECOIMENDATIONS}

The preceding data do not invalidate the position that there are basic divinely inspired principles that should form the basis for any church organizational structure and administrative function. While the structure and functions are not sacrosanct in every detail, their source as :Jell as the crucible of experience from which they emerge gives them legitimacy. Within these parameters there must still he room for adaptation and change. These adaptations and changes must be willingly addressed by the church leadership or they will be forced upon church administrators in a much less palatable form.

\section{Specific Conclusions}

The findings of this study lead to several specific conclusions:

1. Many delegates to the constituency session (both lay people and denominational employees) are not satisfied with the way the church leaders are currently conducting church business.

2. A fair proportion of the delegates to the constituency sessions believe that despite the fact that they are cormissioned to elect officers and conduct the other business of the church they actually have very little meaningful input. llany perceive that 
they are merely asked to approve--"rubber stamp"--iwhat has already been decided.

3. A number of the delegates question the integrity and openness of the constituency session proceedings.

4. 'lany delegates would like additional information prior to the constituency sessions so as to be better prepared to make inforied contributions.

5. ilany of the delegates would prefer spending their time developing future plans for the conference rather than listening to lengthy reports of past "progress."

6. The satisfaction level of the constituents toward their learers and the way they lear can be improved through a conscious and educated effort by administration.

7. lost of the delegates surveyed based their level of satisfaction or dissatisfaction with constituency sessions on their amount of participation in that session.

8. Host of the delegates selected by the local churches are in the over-i0 age group.

9. There is a significant difference in the satisfaction level between delegates 40 years of age and above and those below 40. Delegates below 40 years of age are generally less satisfied with the constituency session proceedings.

Recomnendiations

1. In viev of the fact that the resnonses to question 7 indicated a lowering of the understanding level of the 
proceedings by the delegates, I would suggest the following recommendations:

1. Fewer lay study commissions should report during the time of the sessions. This presents a paradoxical trade-off. The more commissions there are, the nore delegates becone invo?ved and are able to give input. On the other nand, with so many different groups working simultaneously, some inherent confusion ensues thus making some delegates feel they did not understand all that was happening. ilore counsel should be given to those who give reports or presentations. Specifically, this should be done with the lay comission chair persons who, in some cases, were not experienced in communcating effectively to large groups. Additionalty, instruction should be given as to the proper use of handouts, overhead transparencies, and other communication tools.

2. A number of delegates commented on the various aspocts of proper representation in the second section of question $?$. While this issue nay never be totally resolved, it must he addressed. As conferences have grown in size and more lay persons have wanted to be involved, delegate totals have risen to an almost unmanageable size. It appears that having fewer delegates attending would ensure a higier level of delegate participation. For the 1983 Upper Columbia Conference session, this was accoiplished by changing the constitution to allow fever delegates per church nembership.

3. The third section under question ? dealt with the issue of the election process. This is a growing concern to both laity and church administrators. Some would like to see two names nominated for each office as a solution to this problem. I 
disagree with this concept for I fear that a conference could be split due to campaigning for a favorite candidate prior to the session. Officers of conferences could feel forced to hecome politicians, inaking decisions or choices on what would be politically expedient to retain their offices.

I would reconmend making the sessions issue-oriented rather than election-oriented, a position to which they have degenerated in recent years. If delegates feel they can have meaningful input into the plans and operation of a conference, the election process may become less prominent.

4. Under question 9 , tile section on "Prior information," the issue of expediting the changes of the constitution and bylaws was addressed. This has generally been perceived as a necessary inconvenience to the day's activities. While this is true to some degree, it can be improved. The deiegates to the 1983 Upper Columbia Conference constituericy session have attempted to improve this situation by making the constitution and bylaws conmittee a standing committee which functions during the triennium. It is anticipated that this comnittee will be able to get its work done before sessions. Thus any proposed changes could be sent to the delegates prior to the constituency session and voted--hopefully--with little additional discussion at the session. Only further suggestions for change on sections not agreeable to the delegates would need to be debated.

5. Additional stejs shou?d be taken to assure that the general dissemination of information be complete, honest, and factual. Inforration on major issues to be discussed at the 
constituency session should he sent out in advance and include the facts concerning expenses, long-range impact on personnel, and any other factors of inportance. A list of the arguments for and against the decision would be helpful. The delegates would then have the feeling that they could make intelligent decisions based on all the facts and not merely those slanted in favor of the position of the administration.

The potential apparent in this project for improvenent of the credibility and satisfaction levels of the laity with their Teadership is very encouraging. The spirit of willing cooperation by all is an omen of good things to come.

6. It is recomended that future studies investigate the relationship between administrative leadership style, attitudes toward adninistration, and satisfaction with the constituency meeting.

7. It is recomended that a North American Division-wide performance appraisal system be established to provide ongoing administrative evaluation data that will improve the election process. 
AP PENDIX

Reproduced with permission of the copyright owner. Further reproduction prohibited without permission. 


\section{The Upper Columbia Conference Wants Your Input}

Some months ago the Conference officers began working with the Lay Advisory Council in preparation for the April 24 Upper Columbia Constituency Session.

A Lay Constituency planning committee was established to give overall direction as plans were developed.

To receive additional direction, a survey was sent to 265 randomly selected delegates to the 1980 session to get their input. To date over 200 have responded.

The planning committee then established seven commissions under the leadership of respected laymen to deal with the areas they felt were of greatest importance for the next three years. They are as follows (see back for additional information):

\section{Educational Finance UCA Development \\ Total \& Well-rounded Evangelism \\ Nurture \& Assimilation \\ Financial Concerns \& Directions \\ Strengthening the Role of the Laity \\ Improving the SDA Image}

It is the desire of the Conference officers that you share your ideas and concerns in the area of your expertise with the lay chairmen for the commissions' consideration. This can be done by letter, phone, or in person at one of the next commission meetings held at various locations around the Conference.

The proposals developed by the seven commissions will go to the Lay Advisory Council and then in turn be brought to the floor of the Constituency Session for approval by the delegates at large.

This is a serious attempt to receive the direction from the constituency that the Conference officers and departmental leaders need and want as they plan for the next three years.

Thank you for taking this opportunity to be involved in the future of our church in the Upper Columbia Conference. If you have further questions please call:

Jere Patzer

Executive Secretary

(509) 838-2761 


\section{CONSTITUENCY SESSION PLANNING COMMISSIONS}

\begin{tabular}{|c|c|c|c|}
\hline Commisalon & Chairman & Phono No. & Addrees \\
\hline Educational Finance & Eldon Spady & (503) $276-4426$ & $\begin{array}{l}1522 \text { S.W. 40th Place } \\
\text { Pendleton, OR } 97801\end{array}$ \\
\hline UCA Development & Stan Smick & (509) 747-4397 & $\begin{array}{l}\text { S. } 4008 \text { Skyvlew Drive } \\
\text { Spokane, WA } 99203\end{array}$ \\
\hline Total \& Well-rounded Evangelism & Vern Prewitt & (509) 466-8968 & $\begin{array}{l}\text { W. } 1503 \text { Ardmore Drive } \\
\text { Spokane, WA } 99218\end{array}$ \\
\hline Nurture \& Assimilation & Richard Mehrer & (509) 663-1753 & $\begin{array}{l}1335 \text { Washington } \\
\text { Wenatchee, WA } 98801\end{array}$ \\
\hline Financial Concerns \& Directions & Paul Joice & (509) 525-3256 & $\begin{array}{l}612 \text { Scenic View Drive } \\
\text { College Place, WA } 99324\end{array}$ \\
\hline Strengthening the Role of the Laity & Len Harms & (509) 545-9043 & $\begin{array}{l}1705 \text { Road } 64 \\
\text { Pasco, WA } 99301\end{array}$ \\
\hline Improving the SDA Image & Loren Dickinson & (509) 529-5955 & $\begin{array}{l}1222 \text { Dewey Drive } \\
\text { Coilege Place, WA } 99324\end{array}$ \\
\hline
\end{tabular}




\section{APPENDIX B \\ UPPER COLUMBIA CONFERENCE TRIENNIAL SESSION \\ AGENDA \\ April 24, 1983}

9:15 a.m.

Organ Prelude/Opening Song

9:30 a.m.

Prayer Richard D. Fearing Welcome/Introductions ................... Donald G. Reynolds

"From This Day On". Choraliers

"The Basis of Our Confidence" R. R. Bietz

10:05 a.m.

Reading of the Call Jere D. Patzer

Seating of Delegates

Remarks

10:15 a.m.

Call to Order

Acceptance of New Churches

Donald G. Reynolds

10:25 a.m.

Large Committee Report

Richard D. Fearing

10:30 a.m.

"After the Master" - A Multimedia Report

Donald G. Reynolds

11:05 a.m.

Multimedia Reponse

Jere D. Patzer

11:15 a.m.

Commission Presentations (in groups)

Lunch (in Commission groups)

1:00 p.m.

Nominating Committee Report

1:10 p.m.

Conference Financial Statement

Donald L. Folkenberg

Corporation Financial Statement Lee F. Anderson

1:30 p.m.

Commission Reports \& Recommendations .......... Jere D. Patzer Education Finance ...................... Eldon Spady Upper Columbia Academy Development ............ Stan Smick Total and Well-rounded Evangelism ............... Vern Prewitt Nurture and Assimilation ....................Richard Mehrer Financial Concerns and Directions ............... Paul Joice Strengthening the Role of the Laity ................ Len Harms Improving the SDA Image ................... Loren Dickinson

\section{Special Presentation}

3:00 p.m.

Davenport Update . Donald G. Reynolds

3:30 p.m.

Final Reports and Discussion Constitution and Bylaws Committee

Credentials and Licenses Committee Nominating Committee

Plans Committee

4:30 p.m.

"Challenge for the Eighties"

C. E. Bradtord

4:45 p.m.

Benediction Gordon Birchell

THE LARGE COMMITTEE WILL CONVENE SATURDAY NIGHT. APRIL 23. AT 6:30 FOR WORSHIP IN THE CONFERENCE OFFICE ASSEMBLY ROOM, PRECEDING ITS FORMAL MEETING. 
EVALUATION

In the interest of improving the efficiency and effectiveness of conference tituency sessions, the following survey has been developed. As a participant in last conference session, you have been randomly selected to candidly and anonyly express your opinion. Thank you for taking a few minutes to fill out the surand then sending it back by return mail.

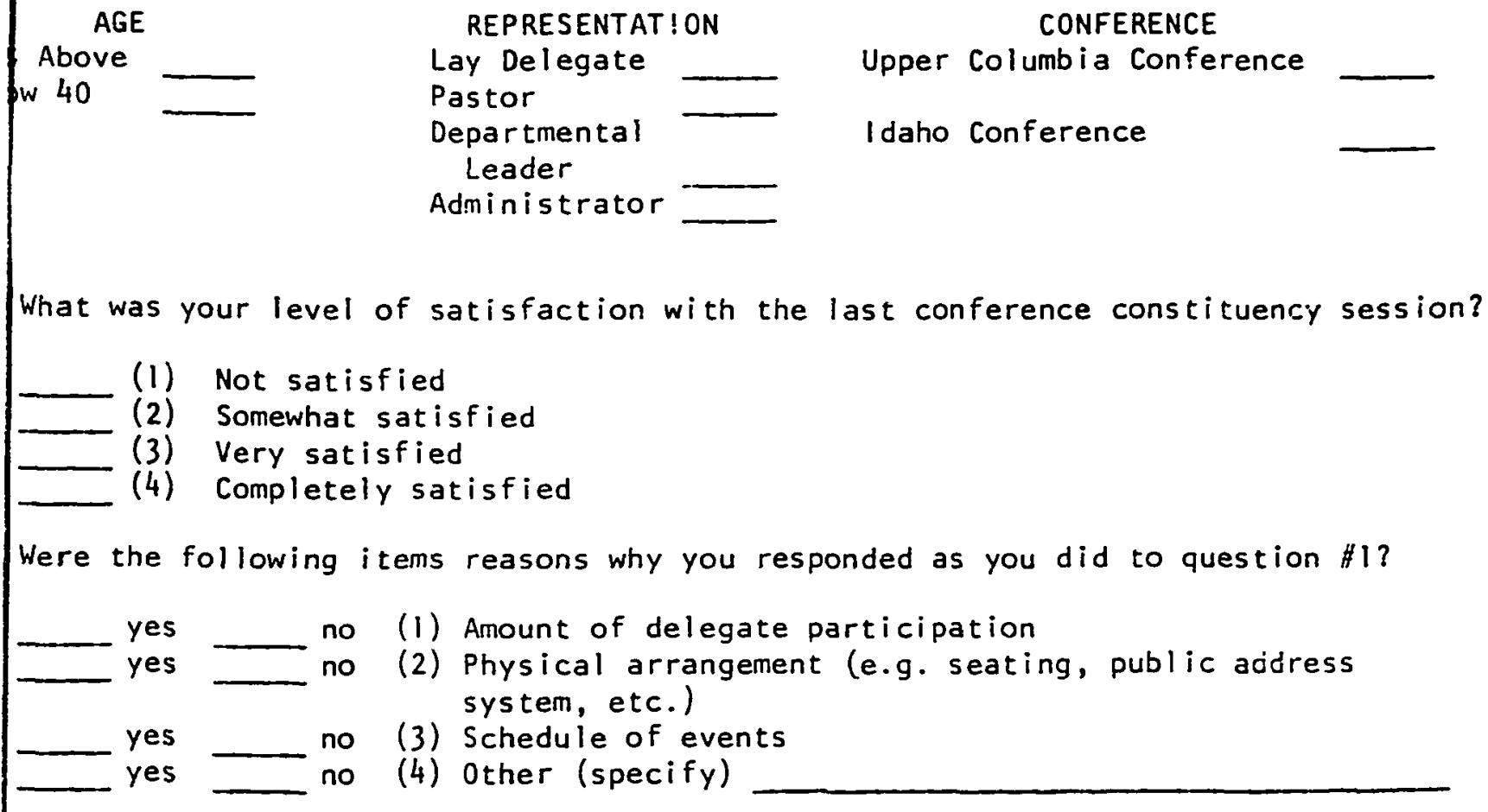

To what extent did you feel the session was structured to be honest and open?

(1) Not at all

(2) A little

(3) Somewhat

(4) Quite a bit

(5) Completely

To what extent did you feel the structure of the session allowed for your meaningful input in areas of plans, programs and objectives for the next triennium?

(1) Not at all

(2) A little

(3) Somewhat

(4) Quite a bit

(5) A lot

As a result of that session, your confidence in church leadership:

(1) grew considerably.

(2) grew somewhat.

(3) stayed the same.

(4) diminished somewhat.

(5) diminished considerably.

Reproduced with permission of the copyright owner. Further reproduction prohibited without permission. 


\section{APPENDIX C-2}

If you could improve the next session, which of the following things would you do? Put 1 by the most important, 2 by the next most important, etc.

(1) Limit attendance to delegates only.

(2) Involve more delegates in committee work.

(3) Devise another way of electing conference leadership.

(4) Allow more discussion during business meetings.

(5) Include more programs for spiritual growth.

(6) Give departments more time to report.

(7) Give more opportunity for input into plans and objectives of conference.

(8) Other (specify)

How much of the proceedings did you understand?
(1) None
(2) Little
(3) Half
(4) Most
(5) All

What is the purpose of constituency sessions? Put 1 by the most important purpose, 2 by the second most important, etc.

(1) Elect church leadership.

(2) Hear reports of past accomplishments.

(3) Give input to leadership on goals, plans, ideas for future.

(4) Hear reports of future plans and objectives.

(5) Renew commitment to the church.

What other suggestions would you like to make that would make the upcoming constituency sessions more effective and efficient? 
July 6, 1982

RE: CONFERENCE CONSTITUENCY SESSIONS

Dear Church Leader:

Considerable thought and discussion has been given recently to the traditional format for Conference Constituency Sessions. Some feel that changes could be implemented to increase the efficiency and effectiveness of these important meetings. You have been randomly selected through the use of a computer to candidly express your opinion of the 1980 Conference Session (the numerical listing is for follow-through purposes, not identification).

The responses will be tallied and sample findings will be passed on to the conference administration for their consideration in planning the 1983 Sessions.

Please take a few minutes to complete the following questionnaire and then return it imediately in the self-addressed envelope. This project is being done in cooperation with Andrews Unviersity. Its success depends on your response. Thank you for your cooperation.

Jere D. Patzer

Jere D. Patzer

Enclosures 
August 6,1982

\section{RE: CONFERENCE CONSTITUENCY SESSIONS}

\section{Dear Church Leader:}

One month ago we mailed a survey to a randomly selected sample group of constituents requesting their input into the planning of the upcoming constituency session. This information was to be derived from their recollections of the last session at which they were delegates.

I am pleased to inform you that already we have presented a partial report to the Upper Columbia Conference Lay Constituency Planning Comnittee based on these returns. They appreciated the general feelings and specific suggestions expressed and are now working on the implementation for the upcoming session. We hope to pass this same information on to the Idaho Conference for their evaluation when the report is completed.

According to our records, we have not yet received your survey. Due to the nature of the study we need a very high rate of return to make the study valid and therefore want to encourage you to take five minutes and fill out the enclosed survey.

If you did not attend the last session, we would like to receive your suggestions anyway. If for some reason you choose not to give any information--which hopefully will not be the case--please mail the blank survey back in the seli-addressed envelope and we will not pursue your input further.

The Constituency Session can be, we feel, one of the most constructive mediums for lay input into the operation of our church. Thank you for taking this opportunity to constructively give your direction in this important area.

\section{Jere D. Patzere}

Jere D. Patzer

ja

\section{Enclosures}

P.S. If your response has been mailed in and therefore passed this letter in the mail, please disregard this second notice. 
October 7, 1982

RE: CONFERENCE CONSTITUENCY SESSIONS

Dear Church Leader:

We have been extremely pleased with the fact that of the 430 surveys sent out, 335 have currently been returned. However, inasmuch as this study is being conducted in conjunction with the Andrews University Institute of Church Miristry, it has been suggested that we write again to encourage you to respond. Obviously, the higher the rate of response, the more valid the study.

Again, be assured of your anonymity. The stamped numbers are purely for the purpose of sending additional reminders to those who did not respond initially.

If for some reason you still choose not to respond, please mail in the questionnaire anyway and wite "No Comment" across the top. You will not receive additional mailings.

The Constituency sessions can be such a vital part of the operation of our church if used effectively for lay input and evaluation. Already in the Upper Columbia Conference many hours have been spent in planning the April session to incorporate greater lay involvement. Upon completion of the survey, this information will also be turned over to the Idaho Conference for their evaluation and subsequent planning.

Thank you for taking 5 or 10 minutes right now to let your voice be heard. Believe me, we want to hear from you.

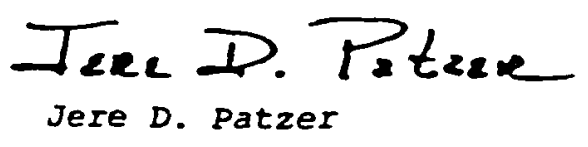

$J D P / j$

enclosures 


\section{EXPLANATION OF CONFERENCE TRIENNIAL SESSION PROCEDURE UPPER COLUMBIA CONFERENCE April 24, 1983}

PURPOSE:

The Upper Colunbia Conference is a cooperative organization of local Seventh-day Adventist congregations bound together for the mutual purpose of preaching the gospel of salvation.

Every three years representatives from the churches comprising the Upper Columbia Conference convene to:

(1) Receive progress reports of the previous triennium

(2) Elect Conference officers and departmental directors

(3) Lay plans for furthering the work of the church

The Conference session business will be conducted in harmony with the Working Policy of the General Conference.

\section{DELEGATE RESPONSIBILITY}

Each church in the Conference has appointed delegates on the basis of church membership--two delegates for each church, plus one delegate for each 60 members or major fraction. Delegates appointed by the church are to loyally represent the best interest of the church at large. The delegates should unite in prayer and dedication to transact the business of the session in such a way as to further the work of the gospel.

The information given in the reports is to be shared by the delegates with the members of their respective churches. Some delegates will be nominated to serve on the various working committees of the session. The delegates will vote on the nominations and recommendations presented by the session committees.

PROCEDURE

(1) Only delegates appointed by the local churches within the territory of the Conference and such delegates-at-large as provided for in the constitution will be recognized to participate in the business of the Conference session.

(2) Early in the session the delegates will be seated, and they are then authorized to participate in the business of the conference session.

(3) The members of the Large Committee will meet at 7:00 p.m. (6:30 p.m. for sundown worship), April 23, and make nominations for the various working committees of the session such as:
(a) Nominating
(b) Constitution and by-Laws
(c) Credentials and Licensing 
101

(4) Delegates inay present their sugPENDStions regarding matters Dertaining to the work in the Upper Columbia Conference to the proper session cormittees.

(5) Following study by these various committees, recommendations will Je brought to the "floor" of the large assembly for final consideration.

(6) In addition to the standing committees the seven commission inairmen will present their cormission reports to those who choose to meet in their group. A brief final report with possible recommendations will be urought to the main floor.

(7) Delegates will be given opportunity to voice their opinion regarding any items brought to the session.

(8) The majority vote by the general assembly will constitute the ifficial action of the Conference session.

\section{SESSION COMMITTEES \\ UPPER COLUMBIA CONFERENCE}

\section{JELECTION OF "LARGE COMMITTEE"}

AE GENERAL CONFERENCE WORKING POLICY, (1981 Ed., C 35053 ) calls for the selection of one delegate from each church attending the conference session io serve on the "Large Committee". In conferences with more than 10,000 nembers, one additional member shall be chosen by each church for each full o00 members. (This would provide a total of two members from churches with rembership of 501-1000, three members from churches with membership of 1001-1500, etc.) This group under the chairmanship of the Union Conference resident or his designate will nominate the members of the other session iommittees. These nominations will be brought to the general assembly for -inal appointment to the various session committees.

VOMIINATING COMMITTEE

- ne Union Conference president or his designate shall serve as chairman of ine Nominating Committee. This committee shall consist of 21 members, 60 jercent of whom shall be other than employees of the Conference.

his committee is to bring in nominations for the Conference officers, lepartmental directors, the Conference Executive Committee, and the Board if Education.

ine offices and committee or board positions to be filled are to be nominated by the Nominating Committee and are listed below with the name of ine person presently holding the position:

Presioent

Secretary

Treasurer
Donald G. Reynolds

Jere D. Patzer

Donald L. Folkenberg 
Adventist Book Center Manager

A.S.I.

Communications

Education

Health Education

Ministerial/Stewardship

Personal Ministries

Sabbath School

Trust Services

Youth Activities and

National Service Organization
APPENDIX G-3

Bob Reiber

Donald Folkenberg

Jere Patzer

Carl Jorgensen

Don Parks

David Parks

Curtis Miller

Eston Allen

Roger Heinrich

Clayton Child

\section{UPPER COLUMBIA CONFERENCE EXECUTIVE COMMITTEE}

Jonald G. Reynolds, Chairman

Jere D. Patzer, Secretary

Donald L. Folkenberg

Irene Allen

Joan Beck

Darold bigger

Gordon Birchell

june Dorner

Dan Featherston

Ed Gienger

Jerrel \} Gilkeson

Sain Lefore, Jr.

Rick McCombs

George Ortiz

Randy Phillips

Jerry Pogue

Clayton Prusia

Cliff Sorensen

George Thompson

Ervin Weijohn

Mary Jane Wilkinson
President, Upper Columbia Conference Secretary, Upper Columbia Conference Treasurer, Upper Columbia Conference Layman, Spokane Central Church, WA Layman, Chewelah Church, Washington Pastor, Walla Walla College Church, WA Layman, Spokane Linwood Church, WA Layman, Wenatchee Church, Washington Layman, Sandpoint Church, Idaho Pastor, Walla Walla City Church, WA Pastor, Upper Columbia Academy Church, WA Layman, Milton Church, Oregon Pastor, Moses Lake Church, Washington Layman, Hermiston Church, Oregon Pastor, Osburn-St. Maries Church, Idaho Administrator, Walla Walla General Hospital, Washington Layman, College Place Church, Washington President, Walla Walla College Layman, Clarkston Church, Washington Layman, Wapato Church, Washington Layman, Yakima Church, Washington

\section{BOARD OF EDUCATION}

Donald G. Reynolds, Chairman Alfred Schroetlin, Vice Chmn Carl Jorgensen, Secretary Alvin Benitz

Paul Campanello

David Fisher

Donald Folkenberg

Susan Gardner

Gary Harding

Lee Roy Holmes

Duane Johnson

Lucretia Link

betty Jean Magnuson
President, Upper Columbia Conference Layman, Farmington Church, Washington Education Superintendent, UCC Layman, Pasco Riverview Church, WA He ad Teacher, Pend Oreille SDA School Layman, Othello Church, Washington Treasurer, Upper Columbia Conference Teacher, Walla Walla Valley Academy Layman, Toppenish Church, Washington Pastor, Colville-Northport-Ione Churches, Washington

Layman, WWC Church, Washington

Layman, Endicott Church, Washington

Layman, Quincy Church, Washington 
Jere Patzer

Randy Phillips

Gil Plubell

Rudy Rittenbach

Barclay Seibly

Dale Wagner

\section{CREDENTIALS AND LICENSES COMMITTEE}

This committee is composed of ordained ministers of experience and non-ordained workers or lay members of experience (up to one-third of the membership of the committee). They are to bring in names and recommendations for those who are to carry licenses and credentials from the Upper Columbia Conference.

\section{CONSTITUTION AND BY-LAWS COMMITTEE}

This committee is composed of ministers and laymen with some background in constituional procedure. They are to evaluate suggested changes and recommend additional changes which may be needed in the Constitution and by-Laws during the Triennium.

\section{PLANS COMMITTEE}

The Lay Advisory Council has been serving as the plans committee for the Conference.

May the purpose of our session be to enhance and advance the work of Christ and His church in the Upper Columbia Conference.

Donald G. Reynolds, President

Jere D. Patzer, Secretary 
DATES FOR CONSTITJENCY MAIL OUTS

For April 24, 1383 Session

March 25 (Friday)

March 28 (Monday)

April \& (llonday)

Apri 15 (Tuesday)

April 5 (Tuesday)

April 7 (Thursday)

April 14 (Thursday)
Letter to delegates

I.0./meal tickets Constitution and bylaws Booklet Notice of Large Committee Time change

Multimedia preview

Letter to Large Cormittee

When

Housing

Letter of explanation and card to pastors with new churches

Commission chaimen letter

ifeeting place

Schedule

Time frame

Objectives/instructions

Recommendation

Dynamics of their meetings

Commission reports lone per church)

Packets to NPUC officers 
June 30,1983

TO: UCC CONSTITUENCY DELEGATES

RE: 68th SESSION

As a delegate to the recent Upper Columbia Conference Constituency Session, please respond to the following questionnaire.

We were pleased with the general response to the meeting. This will give us specific directions as to additional improvements that could be made as well as what should remain the same.

Thank you for your prompt response.

Sincerely,

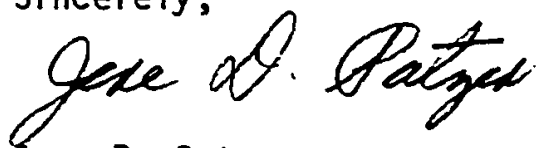

Sere D. Patzer

Executive Secretary

$\mathrm{JDP} / \mathrm{mt} / 0227 \mathrm{e}$

Encl. 


\section{EVALUATION}

In the interest of improving the efficiency and effectiveness of conference constitutency sessions, the following survey has been developed. As a participant in the last conference session, you have been selected to candidly and anonymously express your opinion. Thank you for taking a few minutes to fill out the survey and then sending it back by return mail.

\begin{tabular}{|l} 
AGE \\
40 \& Ab ove \\
Below $40=$
\end{tabular}

CONFERE IICE
Upper Columbia Conference.

1. What was your level of satisfaction with the last conference constituency session?

(1) Not satisfied

(2) Somelihat satisfied

(3) Very satisfied

(4) Cornpletely satisfied

2. Were the following iterns reasons why you responded as you did to questions \#1?
yes
yes $\quad \begin{array}{r}\text { no } \\ \text { no }\end{array}$
(1) Amount of delegate participation
$\square$ yes -
yes
$\square$
(2) Physical arrangement (e.g. seating, public address systen, etc.)
no (3) Schedule of events
no (4) Other (specify)

3. To what extent did you feel the session was structured to be honest and open?

(1) Not at all

$\square \quad$ (2) A little
$-\quad$ (3) Somewhat
$-\quad$ (5) Quite a bit
$-\quad$ (5) Completely

4. To what extent did you feel the structure of the session alloved for your meaningful input in areas of plans, programs, and objectives for the next triennium?
(1) Not at all
(2) A little
(3) Soniewhat
(4) Quite a bit
(5) A $10 t$

5. As a result of that session, your confidence in church leadership:

$\begin{array}{ll}- & \text { (1) Grew considerably } \\ - & \text { (2) Grew somewhat } \\ - & \text { (3) Stayed the same } \\ - & \text { (4) Diminished somewhat } \\ & \text { (5) Diminished considerably }\end{array}$

Reproduced with permission of the copyright owner. Further reproduction prohibited without permission. 
6. If you could inprove the next session, which of the following things rould you do? Put 1 by the most important, 2 by the next most important, etc.

(1) Linit attendance to delegates only.

(2) Involve more delegates in connittee vork.

(3) Devise another way of electing conference leadership.

(4) Allow more discussion during the business meetings.

(5) Include more programs for spiritual growth.

(6) Give departments nore time to report.

(7) Give more opportunity for input into plans and objectives of conference.

7. How much of the proceedings did you understand?

$\begin{array}{lll}\longrightarrow & \text { (1) } & \text { None } \\ \square & \text { (2) } & \text { Little } \\ \square \quad \text { (3) } & \text { Most } \\ \square \quad \text { (4) Al1 }\end{array}$

8. What is the purpose of constituency sessions? Put 1 by the rost important purpose, 2 by the second most important, etc.

(1) Elect church leadership.

(2) Hear reports of past accomplishments.

(3) Give input to leadership on goals, plans, ideas for future.

(4) Hear reports of future plans and objectives.

(5) Renev commitnent to the church.

9. What other suggestions would you like to make that would make the upcoming constituency sessions more effective and efficient? 
If you could improve the next session, which of the following things would you do? (Graphed are the single items voted MOST important.)

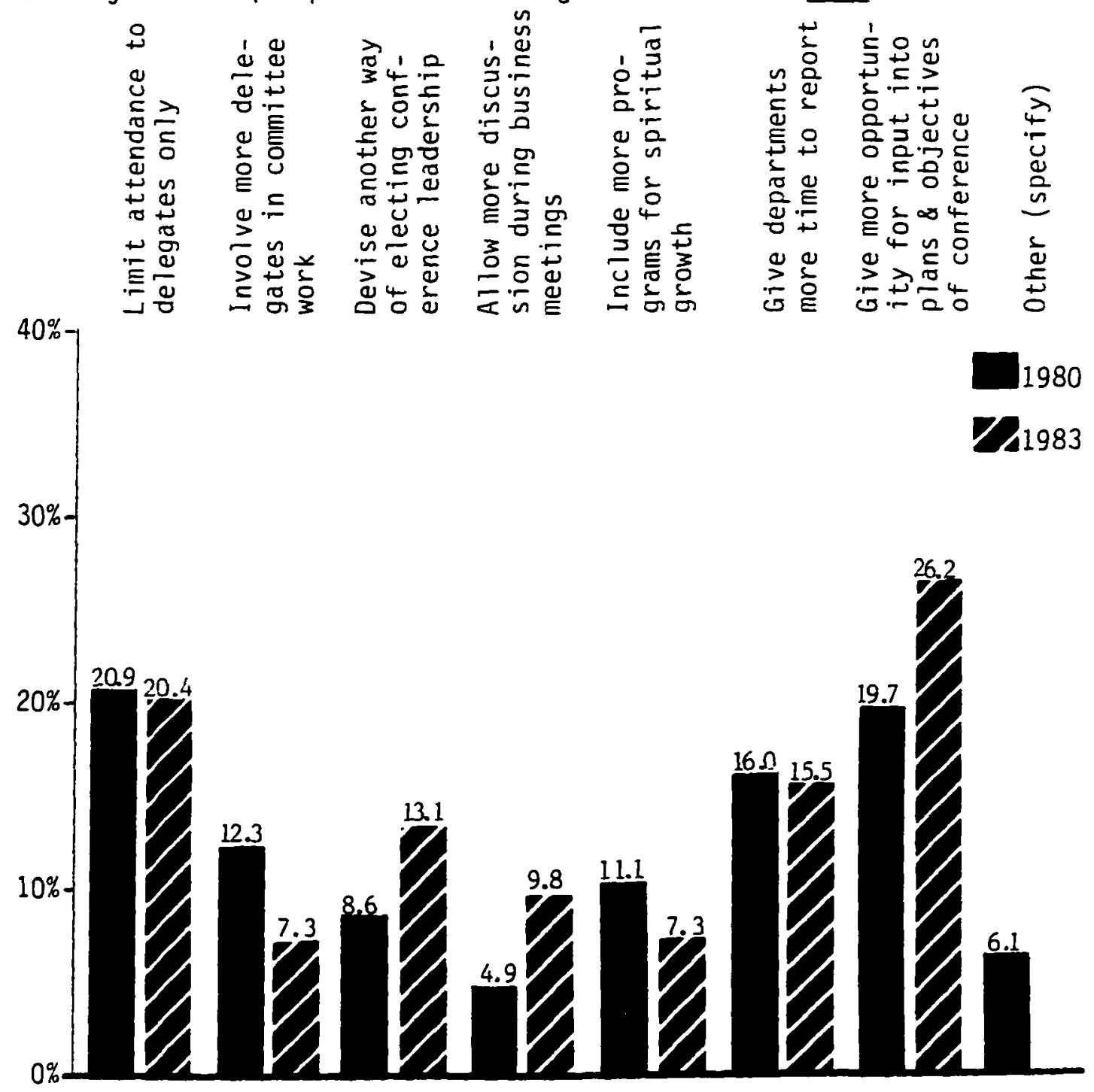

Fig. 7. Response totals by percentage to Question 6 by all groups, i980 Session and 1983 Session 
What is the purpose of constituency sessions?
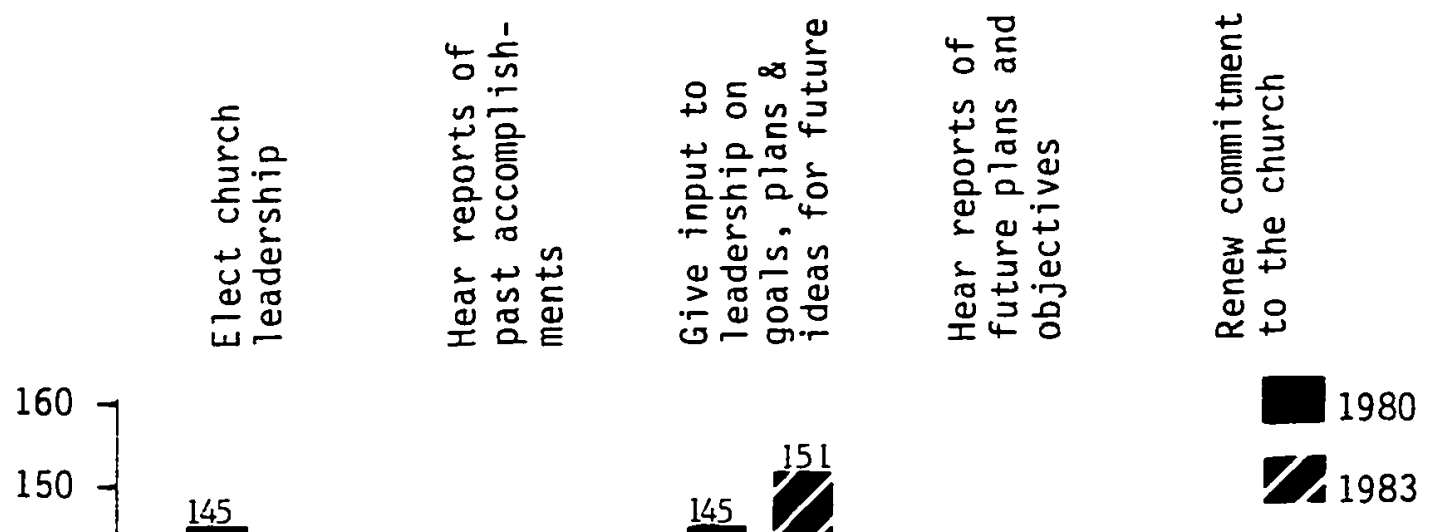
TABLE 11

RESPONSE TOTALS BY WE IGHTED NUMGERS TO CONFERENCE CONSTITUENCY SESSION

EVALUATION COMPARISON OF UPPER COLUMBIA CONFERENCE 1980 ANU 1983 SESSIONS -- QUESTION 3

\begin{tabular}{|c|c|c|c|c|c|c|c|c|c|c|}
\hline \multirow{3}{*}{ Group } & \multicolumn{10}{|c|}{$\begin{array}{l}\text { What is the purpose of constituency sessions? Put } 1 \text { by the } \\
\text { most important purpose, } 2 \text { by the second most important, } \\
\text { etc. } \#\end{array}$} \\
\hline & \multicolumn{2}{|c|}{ 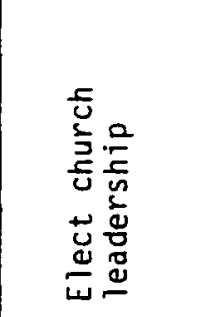 } & \multicolumn{2}{|c|}{ 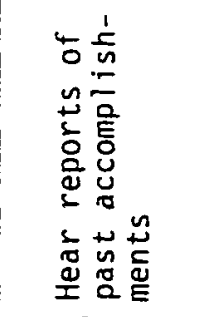 } & \multicolumn{2}{|c|}{ 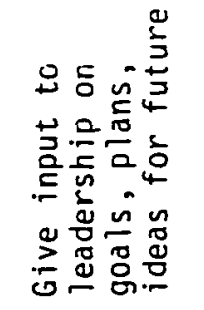 } & \multicolumn{2}{|c|}{ 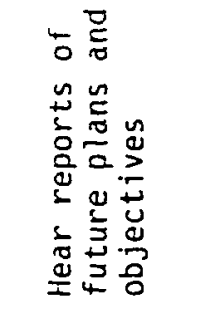 } & \multicolumn{2}{|c|}{ 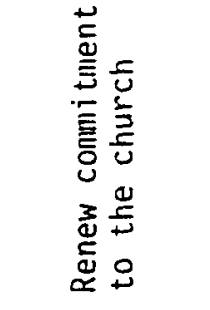 } \\
\hline & 1980 & 1983 & 1980 & 1983 & 1980 & 1983 & 1980 & 1983 & 1980 & 1983 \\
\hline \multicolumn{11}{|l|}{ Age } \\
\hline $\begin{array}{l}40 \text { \& above } \\
\text { Below } 40\end{array}$ & $\begin{array}{r}150 \\
59\end{array}$ & $\begin{array}{l}74 \\
65\end{array}$ & $\begin{array}{l}15 \\
13\end{array}$ & $\begin{array}{r}15 \\
5\end{array}$ & $\begin{array}{r}156 \\
53\end{array}$ & $\begin{array}{l}67 \\
84\end{array}$ & $\begin{array}{l}89 \\
28\end{array}$ & $\begin{array}{l}36 \\
46\end{array}$ & $\begin{array}{l}59 \\
11\end{array}$ & $\begin{array}{l}31 \\
18\end{array}$ \\
\hline $\begin{array}{l}\text { Representation } \\
\text { Lay delegate } \\
\text { Pastor } \\
\text { Dept leader } \\
\text { Administrator }\end{array}$ & $\begin{array}{r}150 \\
51 \\
7 \\
1\end{array}$ & $\begin{array}{r}114 \\
19 \\
6\end{array}$ & $\begin{array}{r}15 \\
10 \\
3\end{array}$ & $\begin{array}{r}18 \\
2\end{array}$ & $\begin{array}{r}157 \\
42 \\
7 \\
3\end{array}$ & $\begin{array}{r}121 \\
27 \\
3\end{array}$ & $\begin{array}{r}101 \\
11 \\
3 \\
2\end{array}$ & $\begin{array}{r}65 \\
14 \\
3\end{array}$ & $\begin{array}{r}49 \\
14 \\
7\end{array}$ & $\begin{array}{r}47 \\
2\end{array}$ \\
\hline All groups & 209 & 139 & 28 & 20 & 209 & 151 & 117 & 82 & 70 & 49 \\
\hline
\end{tabular}

* Only top three ranked are included.

\#Total numbers represent a weighted response. Each $\# 1$ was weighted 3 , each $₹ 2$ was weighted 2 , and each $\$ 3$ was weighted 1 . 
TABLE 12

RESPONSE TOTALS BY NUMBER AND PERCEHTAGE TO CONFEPENCE CONSTITUENCY SF.SSIDN EVALUATIOH ALL QUESTIONS, BY REPRESENTATION

\begin{tabular}{|c|c|c|c|c|}
\hline Question & $\begin{array}{l}\text { Lay } \\
\text { Delegate }\end{array}$ & Pastor & Dept Leader & Administrator \\
\hline $\begin{array}{l}\text { What was your level of satisfaction with } \\
\text { the last conference constituency session? } \\
\text { Not satisfied } \\
\text { Somewhat satisfied } \\
\text { Very satisfied } \\
\text { Completely satisfied } \\
\text { No response } \\
\text { Were the following ttems reasons why you } \\
\text { responded as you did to question } 1 \text { l? } \\
\text { Amount of delegate participation } \\
\text { Satistied } \\
\text { Oissatisfied } \\
\text { Physical drrangement (seating, PA, etc) } \\
\text { Satisfied } \\
\text { Oissatisfied } \\
\text { Schedule of events } \\
\text { Satisfied } \\
\text { Dissatisfied } \\
\text { Other } \\
\text { Satisfied } \\
\text { Dissatisfied }\end{array}$ & $\begin{array}{l}70(28.0 \%) \\
91(36.4 \%) \\
40(16.0 \%) \\
28(11.2 \%) \\
67(26.8 \%) \\
40(16.0 \%) \\
7(2.8 \%) \\
42(16.8 \%)\end{array}$ & $\begin{array}{l}11(26.8 \%) \\
20(48.7 \%) \\
4 \quad(9.7 \%) \\
8(19.5 \%) \\
11(26.3 \%) \\
9(21.9 \%) \\
2(4.8 \%) \\
8(19.5 \%)\end{array}$ & $\begin{array}{ll}3 & (37.5 \%) \\
2 & (25.0 \%) \\
2 & (25.0 \%) \\
1 & (12.5 \%) \\
2 & (25.0 \%)\end{array}$ & $\begin{array}{l}3(00.20) \\
1(20.0 \%) \\
2(40.0 \%) \\
1(20.0 \%) \\
3(60.0 \%) \\
1(20.0 \%)\end{array}$ \\
\hline $\begin{array}{l}\text { To what extent did you feel the session } \\
\text { was structured to be honest and open? } \\
\text { Not dt all } \\
\text { A little } \\
\text { Somewhat } \\
\text { Quite a bit } \\
\text { Completely } \\
\text { No response }\end{array}$ & $\begin{array}{rr}7 & (2.8 \%) \\
20 & (3.0 \%) \\
56 & (22.4 \%) \\
87 & (34.8 \%) \\
64 & (25.6 \%) \\
16 & (6.4 \%)\end{array}$ & $\begin{array}{rr}5 & (12.2 \%) \\
12 & (29.3 \%) \\
16 & (39.0 \%) \\
7 & (17.1 \%) \\
1 & (2.4 \%)\end{array}$ & $\begin{array}{l}2(25.0 \%) \\
6(75.0 \%)\end{array}$ & $\begin{array}{l}1(20.0 \%) \\
1(20.0 \%) \\
3(60.0 \%)\end{array}$ \\
\hline $\begin{array}{l}\text { To what extent did you feel the structure } \\
\text { of the session dllowed for your meaningful } \\
\text { input in areas of plans, programs and ob- } \\
\text { jectives for the next triennium? } \\
\text { Not at all } \\
\text { A little } \\
\text { Somewhat } \\
\text { Quite d oit } \\
\text { A Lot } \\
\text { No response }\end{array}$ & $\begin{array}{lr}34 & (13.6 \%) \\
49 & (19.6 \%) \\
66 & (26.4 \%) \\
62 & (24.8 \%) \\
24 & (9.6 \%) \\
15 & (6.0 \%)\end{array}$ & $\begin{array}{rr}8 & (19.5 \%) \\
11 & (26.8 \%) \\
3 & (19.5 \%) \\
10 & (24.4 \%) \\
3 & (7.3 \%) \\
1 & (2.4 \%)\end{array}$ & $\begin{array}{ll}2 & (25.0 \%) \\
3 & (37.5 \%) \\
2 & (25.0 \%) \\
1 & (12.5 \%)\end{array}$ & $\begin{array}{ll}1 & (20.0 \%) \\
1 & (20.0 \%) \\
2 & (40.0 \%) \\
1 & (20.0 \%)\end{array}$ \\
\hline $\begin{array}{l}\text { As a result of that session, your con- } \\
\text { fidence in church leadersnip: } \\
\text { Grew considerably } \\
\text { Grew somewhat } \\
\text { Stayed the same } \\
\text { Diminisned somewhat } \\
\text { Uiminisned considerably } \\
\text { No response }\end{array}$ & $\begin{array}{rr}20 & (10.4 \%) \\
38 & (15.2 \%) \\
137 & (54.8 \%) \\
20 & (10.4 \%) \\
10 & (4.0 \%) \\
13 & (5.2 \%)\end{array}$ & $\begin{array}{rr}1 & (2.4 \%) \\
5 & (12.2 \%) \\
31 & (75.0 \%) \\
2 & (4.9 \%) \\
1 & (2.4 \%) \\
1 & (2.4 \%)\end{array}$ & $\begin{array}{r}2(25.0 \%) \\
14(50.0 \%) \\
2(25.0 \%)\end{array}$ & $\begin{array}{l}1(20.0 \%) \\
2(00.0 \%)\end{array}$ \\
\hline
\end{tabular}


TABLE 12-Continued

\begin{tabular}{|c|c|c|c|c|}
\hline Question & $\begin{array}{l}\text { Lay } \\
\text { Delegate }\end{array}$ & Pastor & Dept Leader & Administrator \\
\hline $\begin{array}{l}\text { If you could improve the next session, } \\
\text { which of the following things would you } \\
\text { do? Put I py the most important, } 2 \text { by the } \\
\text { next most important, etc.* } \\
\text { Limit attendance to delegates only } \\
\text { Involve more delegated in committee } \\
\text { work } \\
\text { Devise dnother way of electing confer- } \\
\text { ence leadership } \\
\text { Allow more discussion during business } \\
\text { meetings } \\
\text { Include more programs for spiritual } \\
\text { growth } \\
\text { Give departments more time to report } \\
\text { Give more opoortunity for input into } \\
\text { plans \& objectives of conference } \\
\text { Other (specify) } \\
\text { How much of the proceedings did you } \\
\text { understand? } \\
\text { None } \\
\text { Little } \\
\text { Half } \\
\text { Most } \\
\text { All } \\
\text { No response } \\
\text { What is the purpose of constituency ses- } \\
\text { sions? Put I by the most important pur- } \\
\text { pose, } 2 \text { by tne next most important, etc } \$ \\
\text { Elect church leadership } \\
\text { Hear reports of past accomplisnments } \\
\text { Give input to leadership on goals, } \\
\text { plans, ideas for future } \\
\text { Hear reports of future plans } \& \text { ob- } \\
\text { jectives } \\
\text { Review conmittment to the church }\end{array}$ & \begin{tabular}{|rr} 
& \\
& \\
42 & \\
220 & \\
115 & \\
92 & \\
83 & \\
29 & \\
& \\
176 & \\
35 & \\
& \\
& \\
1 & $(.4 x)$ \\
13 & $(5.2 x)$ \\
23 & $(9.2 x)$ \\
143 & $(57.2 x)$ \\
58 & $(23.2 \%)$ \\
12 & $(4.86)$ \\
& \\
&
\end{tabular} & $\begin{array}{l}8 \\
35 \\
14 \\
18 \\
11 \\
41 \\
10\end{array}$ & $\begin{array}{l}2(25.0 \%) \\
6 \quad(75.0 \%)\end{array}$ & $\begin{array}{l}1(20.08) \\
4(80.0 \%)\end{array}$ \\
\hline
\end{tabular}

* Only top three ranked are included.

*Total numbers represent a weighted response. Each $\$ 1$ was weighted 3 , each $\$ 2$ was weighted ?, and each $* 3$ was weignted 1 . 
BIBLIOGRAPHY

Bradford, Charles E. Address given to the Complete Administrator Seminar, Andrews University, Berrien Springs, Michigan, September 5-3, 1983.

Bradford, Leland. llaking lleetings Work. La Jolla, CA: University Associates, $1 \overline{976 .}$

Dennis, Warren G. Changing Organizations. New York: ilcGraw-Hill Co., 1966.

Doyle, llichael, and Strause, David. How to llake lleetings Work. New York: Wayden Books, 1976.

Froom, LeRoy Edwin. Mlovement of Destiny. Washington D.C.: Review and Herald Publishing Association, 1971.

General Conference Working Policy. Washington D.C.: Review and Herald Publishing Association, 1975.

Kung, Hans. Truthfulness: The Future of the Church. Hew York: Sheed and Ward, 1968.

"Local Conference." Seventh-day Adventist Encyclopedia. 1976 edition. 10:346.

Peters, Thomas J., and Waterman, Robert W., Jr. In Search of Excellence. New York: Warner Books, 1983.

Rigg, James H. A Comparative View of Church Organizations, Primitive and Protestant. London: Charles H. Kelley, 1891.

Schindler-Rainman, Eva, and Lippitt, Ronald. Taking Your Meetings out of the Doldrums. La Jolla, CA: University Associates, T979.

Seventh-day Adventist Church Hanual. Washington D.C.: Review and Herald Publishing Association, 1967.

Seventh-day Adventist Yearbook. Washington D.C.: Review and Herald Publishing Association, 1983.

Spalding, Arthur W. Origin and History of Seventh-day Adventists. 4 vols. Washington D.C.: Review and Herald Publishing Association, $1961-1962$. 
White, Ellen G. Acts of the Apostles. Mountain View, CA: Pacific Press Publishing Association, 1971.

- The Great Controversy. Mountain View, CA: Pacific Press Publishing Association, 1950.

- Patriarchs and Prophets. Plountain View, CA: Pacific Press Publishing Association, 1958.

- Supplement to Christian Experience and Views. Battle Creek, MI: Review and Herald Publishing Association, 1854.

- Testimonies for the Church. 9 vols. Washington D.C.: Review and Herald Publishing Association, 1948.

White, James. "Yearly !leetings." Review and Herald, July 21, 1859, p. 68.

Worley, Robert C. Dry Bones Breathe. Chicago: Brethren Press, 1978. 
VITA

\section{Personal}

I was born in Bozeman, Montana; but being the son of Elder and IIrs. A. J. Patzer, a minister and church administrator family, I found that moving would be a part of life. Most of my growing up years were in the East with Takoma Park, Maryland, the place I consider home. I married Susan Isaacson in 1970. In 1973 Jere Darin was born to our family and in 1975, Troy David.

\section{Educational}

My undergraduate degree was from Atlantic Union College in South Lancaster, Massachusetts, in 1969 where I received B.A. degrees in business administration and religion. A Master of Divinity degree was completed at the Seventh-day Adventist Theological Seminary, Andrews University, in 1972. This project is the final step in the completion of the Doctor of Ministry degree with a graduation date set for June 1984. I hope to finish a partially completed llaster of Business Administration degree in the not too distant future.

\section{Professional}

My pastoral ministry in the Seventh-day Adventist Church began in a small three-church district in upstate New York. Later we were called to serve in the state of Pennsylvania. It was there that we began a 10-year career of youth ministry. We served as youth director of the Pennsylvania, Oregon, and North Pacific Union 
conferences respectively. Since 1982 I have been serving as the executive secretary of the Upper Columbia Conference.

To date I have had two small books published by Pacific Press Publishing Association entitled Before You Burn the Rule Book and Bored Again Christian. 